Groundwater Resources Program

\title{
Groundwater Availability of the Mississippi Embayment
}

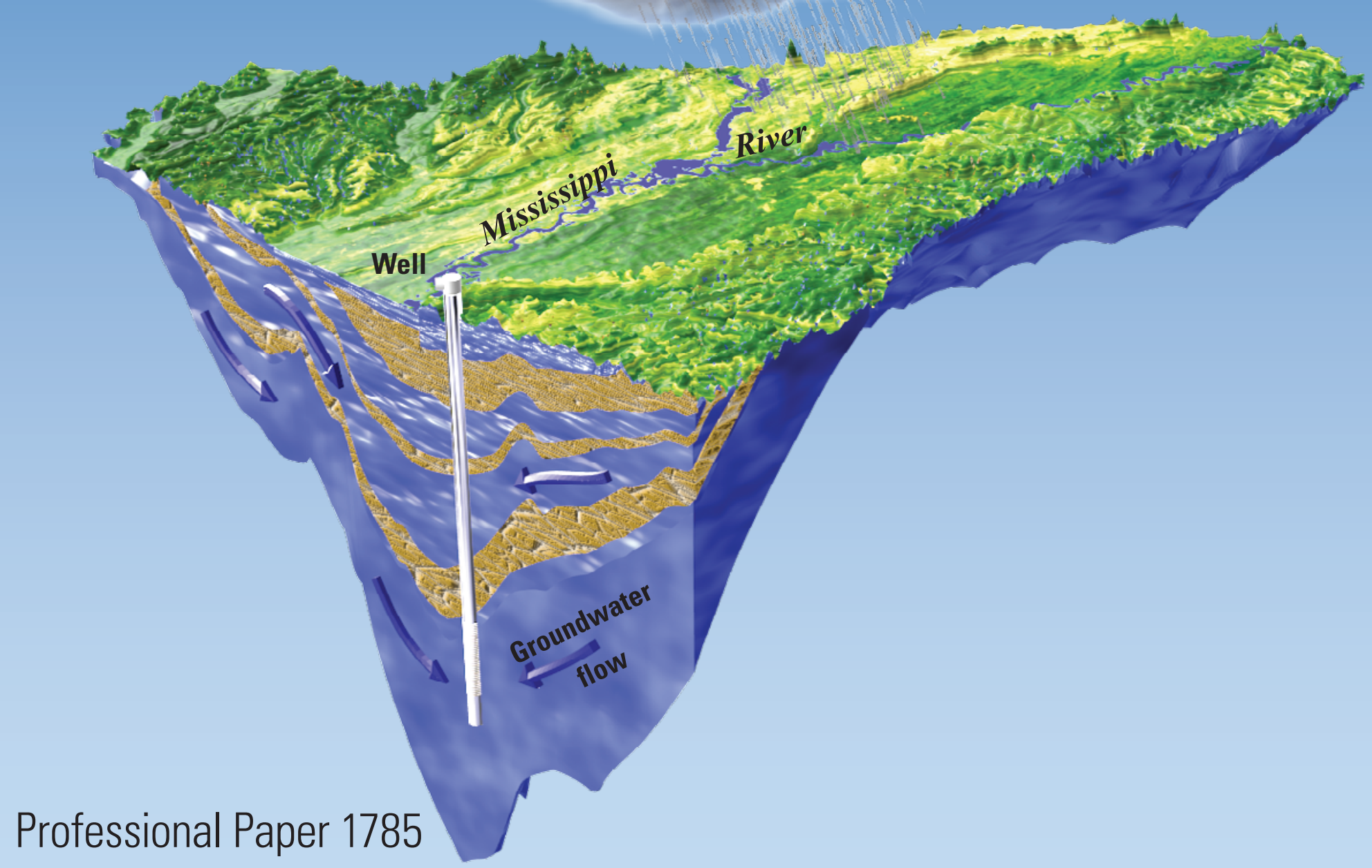


Front cover. Block diagram view of the Mississippi embayment land surface, major rivers, and hydrogeologic units below land surface from the southeast looking northwest. 


\section{Groundwater Availability of the Mississippi Embayment}

By Brian R. Clark, Rheannon M. Hart, and Jason J. Gurdak

Groundwater Resources Program

Professional Paper 1785

U.S. Department of the Interior

U.S. Geological Survey 


\section{U.S. Department of the Interior \\ KEN SALAZAR, Secretary \\ U.S. Geological Survey \\ Marcia K. McNutt, Director}

\section{U.S. Geological Survey, Reston, Virginia: 2011}

For more information on the USGS - the Federal source for science about the Earth, its natural and living resources, natural hazards, and the environment, visit http://www.usgs.gov or call 1-888-ASK-USGS.

For an overview of USGS information products, including maps, imagery, and publications, visit http://www.usgs.gov/pubprod

To order this and other USGS information products, visit http://store.usgs.gov

Any use of trade, product, or firm names is for descriptive purposes only and does not imply endorsement by the U.S. Government.

Although this report is in the public domain, permission must be secured from the individual copyright owners to reproduce any copyrighted materials contained within this report.

Suggested citation:

Clark, B.R., Hart, R.M., and Gurdak, J.J., 2011, Groundwater availability of the Mississippi embayment: U.S. Geological Survey Professional Paper 1785, 62 p.

\section{Library of Congress Cataloging-in-Publication Data}

Clark, Brian R.

Groundwater availability of the Mississippi Embayment / by Brian R. Clark, Rheannon M. Hart, and Jason J. Gurdak.

p. cm. -- (Professional paper ; 1785)

ISBN 978-1-4113-3134-1 (soft cover)

1. Groundwater--Mississippi Embayment. 2. Groundwater--Southern States. 3. Water table--Mississippi Embayment. 4. Water table--Southern States. 5. Aquifers--Mississippi Embayment. 6. Aquifers--Southern States. I. Hart, Rheannon M. II. Gurdak, Jason J. III. Title. IV. Series: U.S. Geological Survey professional paper ; 1785.

GB1018.C53 2011

$551.490975--d c 23$ 


\section{Foreword}

Although often overlooked, groundwater is increasingly important to all our lives. Groundwater is the Nation's principal reserve of freshwater. It provides half our drinking water and is essential to U.S. food production while facilitating business and industry in promoting economic wellbeing. Groundwater is also an important source of water for sustaining the ecosystem health of rivers, wetlands, and estuaries throughout the country.

Large-scale development of groundwater resources with accompanying declines in groundwater levels and other effects of pumping have led to concerns about the future availability of groundwater to meet all our Nation's needs. The depletion of groundwater to satisfy the country's thirst and the compounding effects of recent droughts emphasize the need for an updated status of the Nation's groundwater resources. Assessments of groundwater resources provide the science and information needed by the public and decision makers to evaluate water availability and its effects on the water supply, as well as, to manage and use the water resources responsibly. Adding to this already complex task of resource assessment is the analysis of potential future effects due to climate variability, which can further exacerbate an already challenging situation.

The U.S. Geological Survey's (USGS) Groundwater Resources Program is conducting largescale multidisciplinary regional studies of groundwater availability, such as this study of the Mississippi embayment aquifer system. These regional studies are intended to provide citizens, communities, and natural resource managers with clearer knowledge of the status of the Nation's groundwater resources and how changes in land use, water use, and climate have affected those resources, and to develop tools to forecast how these resources may change in the future. Over time, the findings from these individual regionally integrated groundwater assessments of principal aquifers will be combined to provide a national assessment. Results derived from these studies will provide much needed answers to basic questions about the Nation's ability to meet current and future demands for groundwater.

William H. Werkheiser, Associate Director for Water 


\section{Contents}

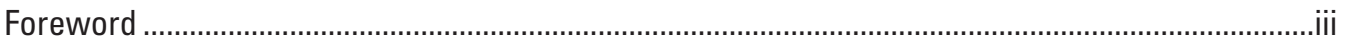

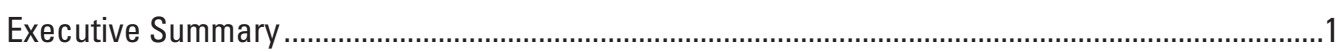

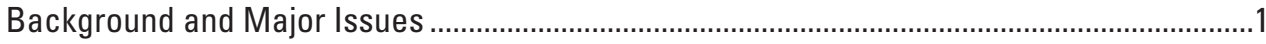

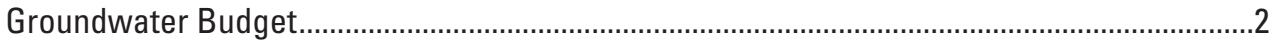

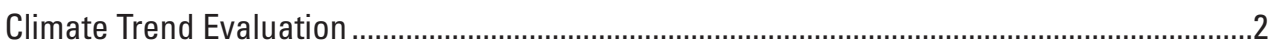

Groundwater Monitoring Evaluation ..................................................................................

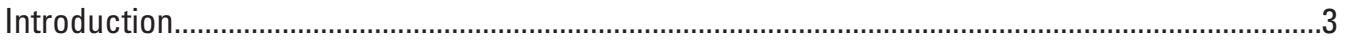

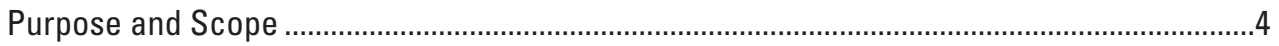

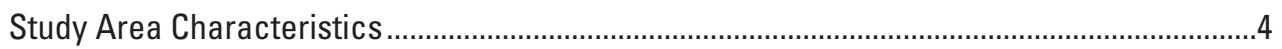

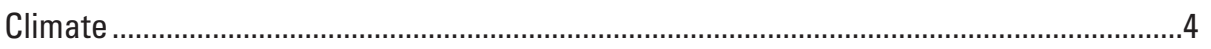

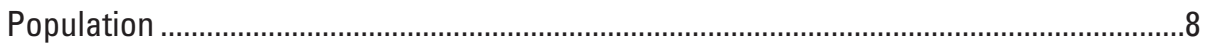

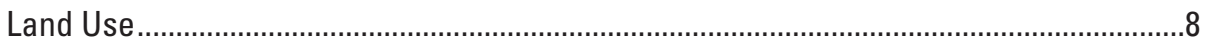

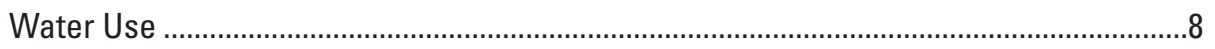

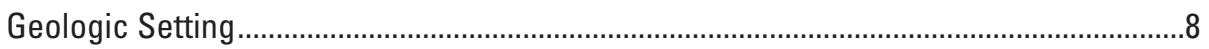

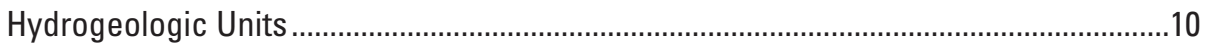

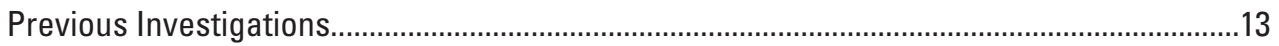

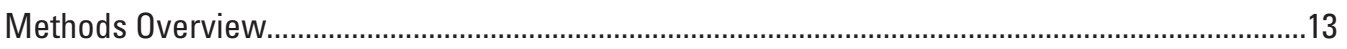

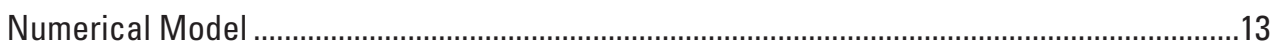

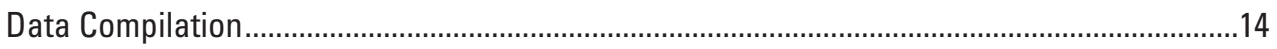

Modifications to the Numerical Model ....................................................................................

Development of the Hydrologic System.................................................................................

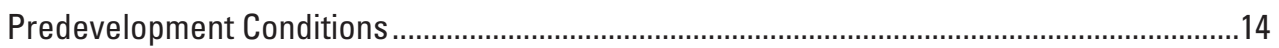

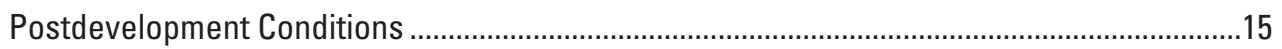

Groundwater Availability, a Water-Budget Perspective ……........................................................17

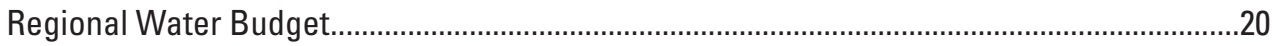

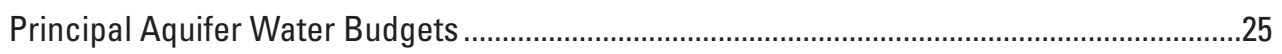

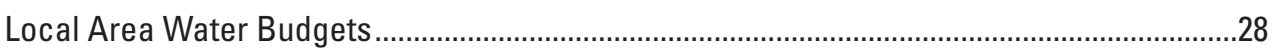

Climate Trends and Potential Future Effects on Groundwater Availability .............................32

Hydroclimate Data Processing and Analysis..................................................................

Climate Simulation Development ....................................................................................35

Climate Trend Scenarios and Simulated Water Levels .................................................36

Evaluation of Regional Groundwater-Level Monitoring Network............................................37

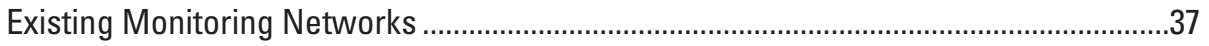

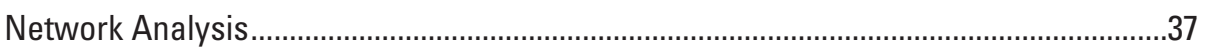

Groundwater-Flow Model Improvements.........................................................................

Challenges for Future Groundwater Availability Determinations-Limitations and

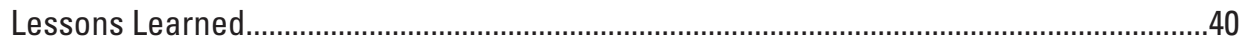

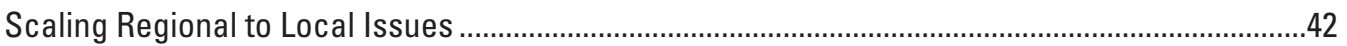

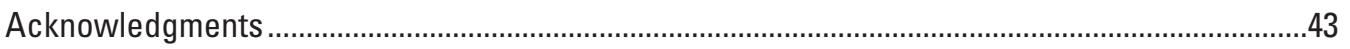

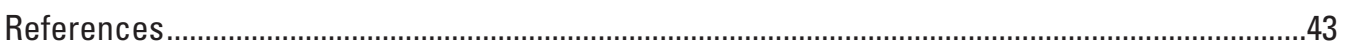

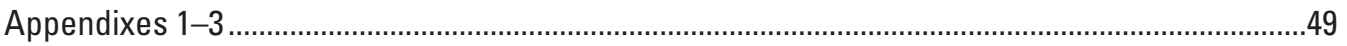


Appendix 1. Effects of Natural-Climate Trends on Interannual to Multidecadal Timescales......50

Appendix 2. Singular Spectrum Analysis ..............................................................................52

Appendix 3. Extrapolated 30-Year Precipitation Values Interpolated Spatially across the Mississippi Embayment Regional Aquifer Study Area ...........................................................58

\section{Figures}

1. Map showing location of the study area and Coastal Plain physiographic province

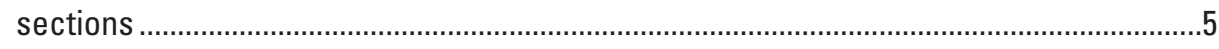

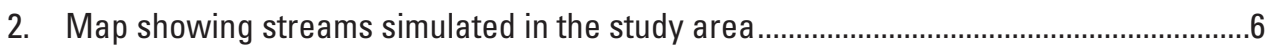

3. Graphs showing cumulative departure from average precipitation within the study area and at selected locations, showing dry and wet periods for the study area ............7

4. Map showing land use within the Mississippi embayment.............................................

5. Graph showing cumulative groundwater pumpage by aquifer used in the Mississippi Embayment Regional Aquifer Study model ....................................................10

6. Cross-sectional view of hydrogeologic units within the study area with

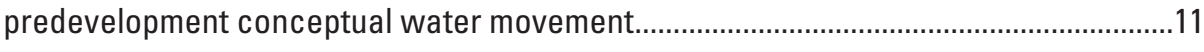

7. Map showing simulated predevelopment streamflow leakage .....................................16

8. Diagram showing predevelopment groundwater-flow budget of the alluvial and Tertiary systems, in acre-feet per year ...........................................................................

9. Maps showing comparison of $A, 1929$ and $B, 2006$ potentiometric surface of the

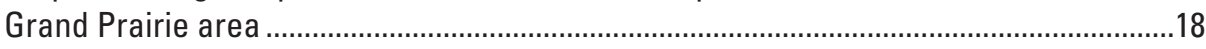

10. Cross-sectional view of hydrogeologic units within the study area with postdevelopment flow (2006) conceptual water movement.

11. Diagram showing postdevelopment groundwater-flow budget of the alluvial and Tertiary systems in acre-feet per year.

12. Graphs showing groundwater-flow budget of the MERAS model $A$, seasonal after 1986, spring/summer depicted by large net pumpage and fall/winter depicted by small net pumpage; $B$, average annual..

13. Graph showing cumulative change in groundwater storage by aquifer ........................22

14. Map showing water-level change from predevelopment to 2007 in the

$A$, Mississippi River Valley alluvial aquifer and $B$, the middle Claiborne aquifer

15. Pie charts showing percent area for water-level change groups from predevelopment to 2007 in the Mississippi River Valley alluvial aquifer and the middle Claiborne aquifer

16. Graphs showing groundwater-flow budget of the alluvial aquifer $A$, seasonal after 1986, spring/summer depicted by large net pumpage and fall/winter depicted by small net pumpage; $B$, average annual..

17. Graphs and pie chart showing groundwater-flow budget of the middle Claiborne aquifer.

18. Graphs showing groundwater-flow budgets of local areas.

19. Pie charts showing predevelopment groundwater-flow interactions with adjacent hydrogeologic units within local areas.

20. Pie charts showing postdevelopment groundwater-flow interactions with adjacent hydrogeologic units within local areas

21. Graphs showing demonstration of hydroclimate data-processing steps using $A$, total monthly precipitation time series, $B$, monthly cumulative departure (MCD), and $C$, normalized departure series. 
22. Graph showing average annual (2-year or more) precipitation values used in the MERAS model and selected meteorological stations including extrapolated precipitation data from 2008 to 2038 .

23. Graph showing specified net recharge at selected locations including extrapolated net recharge from 2008 to 2038

24. Graph showing relation between fractional change in pumping from 2005 and fractional change in precipitation at Memphis, Tennessee, from 2005

25. Pie charts showing percent area for water-level change groups from predevelopment to 2038 in the Mississippi River Valley alluvial aquifer and the middle Claiborne aquifer (dry and wet scenarios).

26. Maps showing water-level change of the dry scenario from predevelopment to 2038 in the $A$, Mississippi River Valley alluvial aquifer and $B$, the middle Claiborne aquifer.

27. Map showing results of OPR-PPR showing the relative importance of spring 2007 water-level observations in the middle Claiborne aquifer

1-1. Graphs showing interactions between the positive and negative phases of the $A$, multivariate El Niño/Southern Oscillation (ENSO) index, $B$, Pacific Decadal Oscillation (PDO) index, and $C$, Atlantic Multidecadal Oscillation (AMO) index cumulatively affect United States climate and, in turn, surface and groundwater resources

2-1. Graphs showing statistically significant reconstructed components based on the Chi-squared significance test from the singular spectrum analysis for time series of $A$, precipitation at meteorological stations, $B$, streamflow at streamflow-gaging stations, and $C$, groundwater levels at wells from the study area indicate that all time series contain variations that are consistent with El Niño Southern Oscillation (2 to 6 years), Pacific Decadal Oscillation (10 to 25 years), and greater than Pacific Decadal Oscillation (greater than 25 years) periods, which are indicated by the gray shading. Additional variations with periodicities of 6 to 10 years were observed in all three types of hydrologic time series

3-1. Maps showing the extrapolated 30-year precipitation values interpolated spatially across the Mississippi Embayment Regional Aquifer Study area are shown as $A$, 2-year average extrapolated annual precipitation (in inches) and as $B$, deviation of the 2-year average extrapolated annual precipitation from the average observed annual precipitation (in percent) for the time period 2008 to 2038

\section{Tables}

1. Correlation of hydrogeologic units across States within the Mississippi Embayment Regional Aquifer Study

2-1. Summary of the period and percent variance for reconstructed components from the singular spectrum analysis 


\section{Conversion Factors}

Inch/Pound to SI

\begin{tabular}{|c|c|c|}
\hline Multiply & By & To obtain \\
\hline \multicolumn{3}{|c|}{ Length } \\
\hline inch (in.) & 2.54 & centimeter $(\mathrm{cm})$ \\
\hline foot $(\mathrm{ft})$ & 0.3048 & meter $(\mathrm{m})$ \\
\hline mile (mi) & 1.609 & kilometer $(\mathrm{km})$ \\
\hline \multicolumn{3}{|c|}{ Area } \\
\hline square mile $\left(\mathrm{mi}^{2}\right)$ & 259.0 & hectare (ha) \\
\hline \multicolumn{3}{|c|}{ Volume } \\
\hline acre-foot (acre-ft) & 1,233 & cubic meter $\left(\mathrm{m}^{3}\right)$ \\
\hline \multicolumn{3}{|c|}{ Flow rate } \\
\hline acre-foot per year (acre-ft/yr) & 1,233 & cubic meter per year $\left(\mathrm{m}^{3} / \mathrm{yr}\right)$ \\
\hline cubic foot per second $\left(\mathrm{ft}^{3} / \mathrm{s}\right)$ & 0.02832 & cubic meter per second $\left(\mathrm{m}^{3} / \mathrm{s}\right)$ \\
\hline gallon per minute (gal/min) & 0.06309 & liter per second $(\mathrm{L} / \mathrm{s})$ \\
\hline gallon per day (gal/d) & 0.003785 & cubic meter per day $\left(\mathrm{m}^{3} / \mathrm{d}\right)$ \\
\hline million gallons per day (Mgal/d) & 0.04381 & cubic meter per second $\left(\mathrm{m}^{3} / \mathrm{s}\right)$ \\
\hline billion gallons per day (Ggal/d) & 43.81 & cubic meter per second $\left(\mathrm{m}^{3} / \mathrm{s}\right)$ \\
\hline inch per year (in/yr) & 25.4 & millimeter per year (mm/yr) \\
\hline
\end{tabular}

Temperature in degrees Celsius $\left({ }^{\circ} \mathrm{C}\right)$ may be converted to degrees Fahrenheit $\left({ }^{\circ} \mathrm{F}\right)$ as follows:

$$
{ }^{\circ} \mathrm{F}=\left(1.8 \mathrm{x}^{\circ} \mathrm{C}\right)+32
$$

Temperature in degrees Fahrenheit $\left({ }^{\circ} \mathrm{F}\right)$ may be converted to degrees Celsius $\left({ }^{\circ} \mathrm{C}\right)$ as follows:

$$
{ }^{\circ} \mathrm{C}=\left({ }^{\circ} \mathrm{F}-32\right) / 1.8
$$

Vertical coordinate information is referenced to the National Geodetic Vertical Datum of 1929 (NGVD 29).

Horizontal coordinate information is referenced to the North American Datum of 1983 (NAD 83).

Altitude, as used in this report, refers to distance above the vertical datum.

*Transmissivity: The standard unit for transmissivity is cubic foot per day per square foot times foot of aquifer thickness $\left[\left(\mathrm{ft}^{3} / \mathrm{d}\right) / \mathrm{ft}^{2}\right] \mathrm{ft}$. In this report, the mathematically reduced form, foot squared per day $\left(\mathrm{ft}^{2} / \mathrm{d}\right)$, is used for convenience.

Specific conductance is given in microsiemens per centimeter at 25 degrees Celsius $(\mu \mathrm{S} / \mathrm{cm}$ at $\left.25^{\circ} \mathrm{C}\right)$.

Concentrations of chemical constituents in water are given either in milligrams per liter (mg/L) or micrograms per liter $(\mu \mathrm{g} / \mathrm{L})$. 


\section{Acronyms}

$\begin{array}{ll}\text { AMO } & \text { Atlantic Multidecadal Oscillation } \\ \text { ENSO } & \text { El Niño Southern Oscillation } \\ \text { ET } & \text { Evapotranspiration } \\ \text { GCRASA } & \text { Gulf Coast Regional Aquifer-System Analysis } \\ \text { GCM } & \text { Global Climate Model } \\ \text { NAMS } & \text { North American Monsoon System } \\ \text { MERAS } & \text { Mississippi Embayment Regional Aquifer Study } \\ \text { MNW } & \text { Multi-Node Well } \\ \text { PDO } & \text { Pacific Decadal Oscillation } \\ \text { RASA } & \text { Regional Aquifer-System Analysis } \\ \text { SFR } & \text { Streamflow Routing } \\ \text { USACE } & \text { U.S. Army Corps of Engineers } \\ \text { USGS } & \text { U.S. Geological Survey } \\ \text { 3D } & \text { Three Dimensional }\end{array}$




\title{
Groundwater Availability of the Mississippi Embayment
}

\author{
By Brian R. Clark, Rheannon M. Hart, and Jason J. Gurdak
}

\section{Executive Summary}

The study described in this report, initiated by the U.S. Geological Survey in 2006, was designed to evaluate available fresh groundwater reserves within the Mississippi embayment, South-Central United States, as an area within a broader national assessment. The goals of the national assessment are to document effects of human activities on water levels and groundwater storage, explore climate variability effects on the regional water budget, and evaluate the adequacy of data networks at a regional scale. The Mississippi embayment was chosen as a study area in the national assessment because of the substantial dependency on groundwater for agriculture and municipal needs. To provide information to stakeholders addressing the groundwater-availability issues, the U.S. Geological Survey Groundwater Resources Program supported a detailed assessment of groundwater availability through the Mississippi Embayment Regional Aquifer Study (MERAS). This assessment included (1) an evaluation of how these resources have changed over time through the use of groundwater budgets, (2) development of a numerical modeling tool to assess system responses to stresses from future human uses and climate trends, and (3) application of statistical tools to evaluate the importance of individual observations within a groundwater-monitoring network.

This study focuses on multiple spatial and temporal scales to examine changes in groundwater pumping, storage, water-level declines, and sources. The regional scale provides a broad view of the sources and demands on the system with time. The principal aquifer scale provides an evaluation of the changes invoked on the system by differing demands. Lastly, the local scale provides a closer examination of the interaction between different aquifers and confining units and the changes in these interactions under current pumping conditions. By focusing on multiple scales, water-resource managers may utilize this study to understand system response to changes as they affect the system as a whole.

\section{Background and Major Issues}

The MERAS area encompasses approximately 78,000 square miles in an area known as the Mississippi embayment. The study area includes parts of 8 States and
10 primary hydrogeologic units. These hydrogeologic units include two primary aquifers- the Mississippi River Valley alluvial aquifer and the middle Claiborne aquifer.

Arkansas ranks first in the Nation for rice and third for cotton production, with both crops dependent on groundwater as a major source of irrigation requirements. Multiple municipalities rely on the groundwater resources to provide water for industrial and public use, which includes the city of Memphis, Tennessee. The demand for the groundwater resource has resulted in groundwater availability issues in the Mississippi embayment including: (1) declining groundwater levels of 50 feet or more in the Mississippi River Valley alluvial aquifer in parts of eastern Arkansas from agricultural pumping, (2) declining groundwater levels of over 360 feet over the last 90 years in the confined middle Claiborne aquifer in southern Arkansas and northern Louisiana from municipal pumping, and (3) litigation between the State of Mississippi and a Memphis water utility over water rights in the middle Claiborne aquifer.

Population density within the Mississippi embayment is greatest in several large urban areas such as Memphis, Tennessee, Pine Bluff, Arkansas, and Jackson, Mississippi. Increases in population and the movement of people from rural to urban areas have increased the need for large pumping centers. Because of continuing groundwater demand and the resulting concentration of withdrawals, groundwater levels have declined sharply in selected areas. Population increased 2.4 percent in the study area from 2000 to 2005 ; the total population for 2005 was approximately 5,206,000.

An estimated 12 million acre-feet per year (11 billion gallons per day) of groundwater was pumped in 2005 from aquifers in the Mississippi embayment. Irrigation constitutes the largest groundwater use, accounting for approximately 10 million acre-feet per year ( 9 billion gallons per day) in 2000 from the Mississippi River Valley alluvial aquifer in Arkansas, Louisiana, Mississippi, and Missouri, and to a lesser extent in Illinois, Kentucky, and Tennessee. The proportion of groundwater use in the Mississippi embayment is reflected in the pumpage amounts used in a groundwater-flow model of the MERAS area. Cumulative groundwater pumpage from predevelopment through 2007 from the Mississippi River Valley alluvial aquifer amounts to over 280 million acre-feet (enough to cover the entire study area with more than 5 feet of water), or approximately 87 percent of the total cumulative 
amount pumped. The amount pumped from the Mississippi River Valley alluvial aquifer is more than nine times that from the middle Claiborne aquifer, which is the second largest producer of groundwater in the Mississippi embayment. Cumulative groundwater pumped from the middle Claiborne aquifer made up approximately 9 percent of the total, while combined pumping from remaining aquifers made up 4 percent of the total cumulative amount.

\section{Groundwater Budget}

Predevelopment groundwater flow is represented in the MERAS model as a steady-state stress period, assumed to be prior to 1870 . The simulated groundwater-flow budget indicates the largest predevelopment inflow to the system is net recharge to the alluvial aquifer. This inflow is balanced by outflow to gaining streams. Overall, water enters as net recharge to the alluvial aquifer or through outcrop areas of the various hydrogeologic units. Away from the outcrop areas, groundwater flow in the deeper formations is primarily upward into overlying units, ultimately discharging to streams through the alluvial aquifer.

Total net recharge and discharge (sum of inflows or outflows) for the model ranged from about 0.66 million acre-feet per year during predevelopment to 20.16 million acre-feet per year by the end of the simulation (final simulated irrigation period in summer of 2006). This change in the model budget reflects increases in withdrawals compared to predevelopment conditions. Cumulative storage within aquifers simulated in the MERAS model indicates overall depletion of 140 million acre-feet (equivalent to 2.8 feet of water covering the entire study area). An estimate of the volume of freshwater stored in the alluvial aquifer can be made by calculating the thickness of the saturated zone (simulated spring 2007 water table minus bottom of the alluvial aquifer as defined by the MERAS model) and multiplying by the specific yield (ranging from 0.1 to 0.3 ). The volume of freshwater currently (2007) stored in the alluvial aquifer was estimated to be approximately 536 million acre-feet (equivalent to 10.7 feet of water covering the entire study area). The total amount of water removed from aquifer storage to date in the Mississippi embayment equals approximately 26 percent of the amount stored only in the alluvial aquifer. This comparison is provided to gain perspective on the quantity of water pumped from aquifers in the Mississippi embayment. It is unrealistic to assume that all water may be removed by pumping. To do so would substantially affect the performance of wells (the efficiency of pumping is reduced as water levels decline), flow to streams, and likely would affect water quality.

In the Mississippi embayment, groundwater pumping has produced water-level declines across large areas. The change in water level from the predevelopment condition was calculated using the simulated water levels of the alluvial and middle Claiborne aquifers. The water levels representing the predevelopment conditions for the alluvial and middle
Claiborne aquifers were subtracted from the respective water levels at the end of each stress period. Changes in the water level in the alluvial aquifer are noticeable throughout Arkansas and parts of Mississippi; by 2007, 0.7 percent of the alluvial area (216 square miles) exhibit declines of more than 100 feet. Changes in water level in the middle Claiborne aquifer are more dramatic than changes in the alluvial aquifer, with more than 13.3 percent of the aquifer area (7,529 square miles) exhibiting water-level declines of more than 100 feet by 2007 . The largest declines of more than 300 feet in water level in the middle Claiborne aquifer occur in southern Arkansas and northern Louisiana. Most areas within the middle Claiborne aquifer boundary are simulated as confined, and therefore, given a relatively small amount of pumping compared to the alluvial aquifer, water levels decline dramatically. However, because of the smaller amounts of removed water and the confined nature of the aquifer, a rebound of water levels would be likely if pumping ceased in these areas. This is the situation in the middle Claiborne aquifer in southern Arkansas where a concerted effort to reduce pumping has resulted in water-level increases of almost 50 feet since 2004. The reverse is typically true of unconfined aquifers, like the alluvial aquifer, in that although pumping has not resulted in water-level changes as great as those seen in the middle Claiborne aquifer, much more water has been removed. Therefore, a much longer period of time would be required to replenish the aquifer if pumping ceased in the alluvial aquifer.

Postdevelopment inflow to the system is still through net recharge to the alluvial aquifer and the outcrop areas of the several hydrogeologic units, however, the flow between each unit is no longer upward to the alluvial aquifer. Groundwater flow during the summer of 2006 was primarily downward to offset demand from pumping. Early in the model simulation (1870-1920s), the primary components of the water budget were simulated as outflow from stream leakage and inflow from net recharge. As pumpage increased through time, water that would otherwise flow to streams reversed, and net stream leakage became an inflow to the system. The largest reversals began in the mid-1980s, but indications of the reversal began in the early 1960s with a trend in loss of streamflow leakage coupled with the first consistent inflow from storage. While groundwater pumped out of the alluvial aquifer was derived primarily from storage, pumpage out of the middle Claiborne aquifer was derived primarily from other aquifers (up to 15 percent from the alluvial aquifer), followed by flow from storage and net recharge.

\section{Climate Trend Evaluation}

The potential consequences of climate change have been identified as a major concern facing the sustainability of the Nation's groundwater resources. To address this concern, two climate simulations were developed through the use of the MERAS model by extending the simulation period by 30 years to the year 2038 using extrapolated precipitation 
based on frequency analysis of historic climate cycles. For the climate simulations, grids of extrapolated precipitation were input into the MERAS model and converted into extrapolated net recharge.

The first climate scenario (dry scenario) simulated with the MERAS model was designed to represent a primarily dry period with respect to precipitation. The change in precipitation at Memphis, Tennessee, was more highly correlated to change in pumping than other locations, indicating that the amount of pumping may be estimated based on changes in precipitation. Based on this relation, pumping was estimated from 2005 through 2038 that would result from an extrapolated change in precipitation.

The second climate scenario (wet scenario) was constructed to provide a contrast to the dry period simulated with the first scenario by incorporating precipitation from one of the wettest periods (1991) occurring within the study area. Precipitation from 1991 was used as the input for the calculation of net recharge while maintaining the pumping used in the dry scenario so that a direct comparison of the effect of changes in precipitation could be made.

There is little difference between the dry and wet scenarios in terms of percent water-level change. Both scenarios resulted in 14.6 to 13.9 percent of the area containing more than 100 feet of decline, 14.5 to 13.8 percent containing between 75 and 100 feet of decline, and 15.8 to 15.7 percent containing 51 to 75 feet of decline in the alluvial aquifer. The middle Claiborne aquifer water-level changes also were similar between the two scenarios. These scenarios indicate that even with a 25 -percent increase in precipitation from that of the dry scenario, there is little difference in the resultant water levels. This is in large part because of the magnitude of differences between changes in net recharge and changes in pumping. When compared to the volume of water pumped out of the system, the effect of this change in net recharge is negligible.

\section{Groundwater Monitoring Evaluation}

The groundwater-level monitoring network used to construct the 2007 middle Claiborne aquifer potentiometric surface was used as an example case to demonstrate statistical technique and to evaluate the importance of individual groundwater-level observations. To calculate the importance of each water-level observation to a prediction, predictions were specified as water-level altitudes near the end of the dry scenario simulation. These predictions were located near the center of cones of depression. Many of the observations that have a high importance are in close proximity to stressed areas of the aquifer. Some, however, rank higher than might be expected based on location, such as the high relative importance of observations in Mississippi in the southeastern part of the study area. The reasons for the high relative importance of these observations in Mississippi are two-fold: (1) the observations and the nearby predictions share high sensitivity to common parameters, and (2) the observations are in an area of sparse observations making the sensitivities higher than observations in areas where multiple observations exist. The results also indicate relative low importance of many of the observations in southern Arkansas and northern Louisiana. However, the ranking of these observations are based solely on the predictions used in this evaluation. It is important to note that this analysis reflects the importance of observations under the current stress conditions in this particular model. The addition of high volume pumping centers in a relatively unstressed area of the middle Claiborne aquifer may alter these results. This underscores the ability of the technique to evaluate a groundwater-monitoring network under a variety of situations.

\section{Introduction}

Water resources in the Mississippi embayment area have a profound effect on the economy, which is based largely on agriculture. Regarding agricultural commodity acreages within the Mississippi embayment, Arkansas ranks first in the Nation for rice and third for cotton with a total value of over \$2.7 billion, and Mississippi ranks first for aquaculture and fourth for cotton in 2007 with a total value of over $\$ 600$ million (U.S. Department of Agriculture, 2010). These commodities rely on groundwater from the Mississippi River Valley alluvial aquifer, as well as other regional aquifers in the Mississippi embayment. Pumping from the Mississippi River Valley alluvial aquifer ranked third in the Nation for total withdrawals or 12 percent of the total groundwater withdrawals (Maupin and Barber, 2005). As with other areas within the United States, the populace of the Mississippi embayment is concerned with declining water levels and depletion of regionally important aquifers. The greatest issue of concern is the availability of the resource in particular areas within the Mississippi Embayment Regional Aquifer Study (MERAS), which occasionally has brought on litigation. Availability issues in the Mississippi embayment include: (1) declining groundwater levels of $50 \mathrm{ft}$ or more in the Mississippi River Valley alluvial aquifer in parts of eastern Arkansas (Schrader, 2008), (2) declining groundwater levels of more than $360 \mathrm{ft}$ over the last 90 years in the confined middle Claiborne aquifer in southern Arkansas and northern Louisiana (Freiwald and Johnson, 2007), and (3) litigation between the State of Mississippi and a Memphis water utility over water rights in the middle Claiborne aquifer (Charlier, 2010).

A holistic analysis of groundwater-flow systems is increasingly important. Previous studies included the use of models to simulate the groundwater-flow system on a local scale, such as a part of an aquifer, an entire aquifer, or even parts of multiple aquifers. While it is useful to examine parts of the system at local scales, there is a need to look at the larger regional and aquifer scale system to better understand how all the parts interact. To provide information to 
stakeholders addressing the groundwater-availability issues, the U.S. Geological Survey Groundwater Resources Program supported a detailed assessment of groundwater availability through MERAS. This assessment included (1) an evaluation of how these resources have changed over time through the use of groundwater budgets, (2) development of a numerical modeling tool to assess system responses to stresses from future human uses and climate trends, and (3) application of statistical tools to evaluate the importance of individual observations within a groundwater-monitoring network.

\section{Purpose and Scope}

The purpose of this Professional Paper is to describe groundwater availability and factors that affect its sustainability in the Mississippi embayment. This is one of a series of reports documenting results of the MERAS. A companion report by Hart and others (2008) describes the hydrogeologic framework while Clark and Hart (2009) describes the construction and calibration of the groundwater-flow (MERAS) model developed for this study. This Professional Paper includes a description of the historical background of the hydrologic system, analyses of transient water budgets, effects of climate on the groundwater system, and evaluation of a groundwater-monitoring network. The water budgets, effects of climate, and evaluation of the monitoring network were interpreted through use of the groundwater-flow model developed for this study (Clark and Hart, 2009). The assessment builds on previous work that has taken place across the area for many years by Federal, State, and local agencies at a variety of different scales. The focus of analysis is directed primarily at two principal aquifers over the 137 years of recent history.

\section{Study Area Characteristics}

The study area encompasses approximately $78,000 \mathrm{mi}^{2}$ in an area known as the Mississippi embayment and corresponds to the MERAS model area (fig. 1). The study area boundary encompasses parts of 8 States and includes approximately 6,900 linear miles of simulated streams, 70,000 well locations, and 10 primary hydrogeologic units. These hydrogeologic units include two primary aquifers - the Mississippi River Valley alluvial aquifer and the middle Claiborne aquifer (Hart and others, 2008). The study area lies within parts of three physiographic sections (West Gulf Coastal Plain, East Gulf Coastal Plain, and Mississippi Alluvial Plain) of the Coastal Plain physiographic province (fig. 1).

\section{Climate}

Climate within the study area ranges from humid, temperate in the northern part to humid, subtropical in the southern part. Precipitation is usually greater in the southern part of the Mississippi embayment (approximately $56 \mathrm{in} / \mathrm{yr}$ ) than in the northern part (approximately $48 \mathrm{in} / \mathrm{yr}$ ). Precipitation is distributed fairly evenly throughout the year with the greatest amounts generally occurring in April and the least in October (Kleiss and others, 2000). The average temperature ranges from $58^{\circ} \mathrm{F}$ in the north to $66^{\circ} \mathrm{F}$ in the south (Cushing and others, 1970; National Oceanographic and Atmospheric Administration, 2009a). Much of the precipitation is consumed by evapotranspiration. Another large part runs off to the many streams in the study area (fig. 2). Climate within the study area is known to contain modes of natural climate variability including seasonal, interannual, interdecadal, and multidecadal climate variability (McCabe and others, 2004). Some of these modes of variability are likely manifested in a variety of responses in the surface and subsurface hydrology.

Natural-climate patterns that are known to have substantial effect on the hydrology across the United States include the El Niño-Southern Oscillation (ENSO), North American Monsoon System (NAMS), Pacific Decadal Oscillation (PDO), and Atlantic Multidecadal Oscillation (AMO), with the ENSO having the strongest effects on seasonal and year-toyear variations in precipitation in the southeast (U.S. Global Change Research Program, 2010). In the Southeastern United States, above-normal precipitation and below-normal temperatures occurred in approximately 80 percent of the summer events during ENSO years (National Drought Mitigation Center, 2010). These climate patterns can augment or diminish human stresses on groundwater, causing dramatic responses in groundwater levels and storage (Hanson and others, 2004). Much of the previous research of hydrologic response to ENSO, PDO, and AMO have centered on the Western United States, and relatively little is known about the groundwater responses in aquifers of the Southeastern United States or the study area.

Cumulative departure from average precipitation within the MERAS model area indicates that climate can vary spatially and temporally. Temporally, there are five distinct wet periods and six distinct dry periods that occurred from 1895 to 2008 (fig. 3). There is an overall drying trend starting at 1895 and continuing through 1943 with a slight 5-year wet period from 1918 to 1923. Between 1923 and 1970, the climate fluctuates slightly with periods of both wet and dry; however, after 1970 there is an overall 30-year wet period until 2004 where the climate seems to be shifting into a drier period. Spatially, there are differences between the north and south, as well as, the east and west. A dry period exists between 1961 and 1970 for the northeastern site (Memphis, Tennessee) and the western site (El Dorado, Arkansas) and a wet and dry period for the southeastern site (Jackson, Mississippi) for the same time period. A wet period exists from 1983 to 1987 for the southeastern site (Jackson, Mississippi) and the northeastern site (Memphis, Tennessee), while the southwestern (El Dorado, Arkansas) site fluctuates with periods of both wet and dry with an overall wetting trend (fig. 3). 


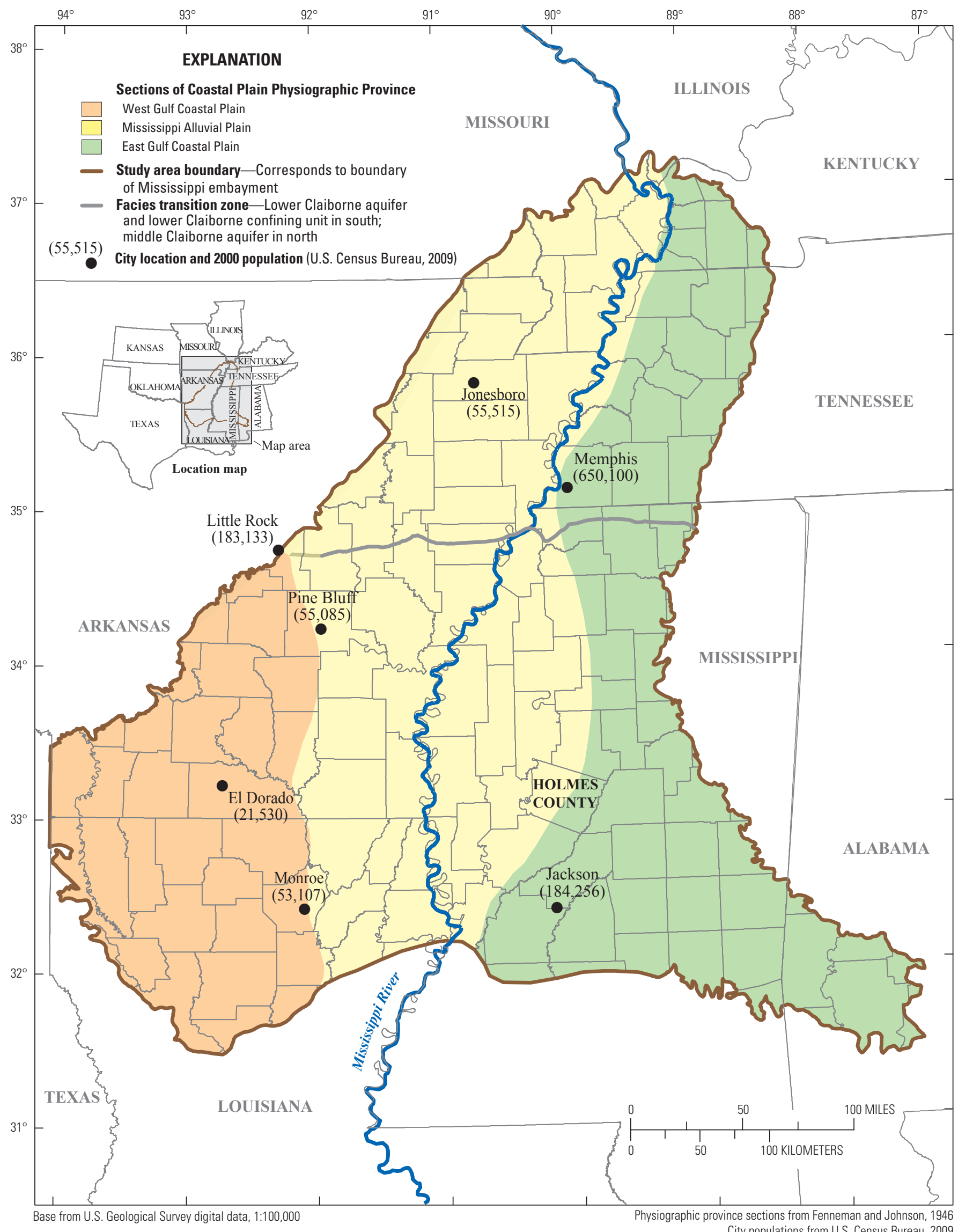

Figure 1. Location of the study area and Coastal Plain physiographic province sections. 


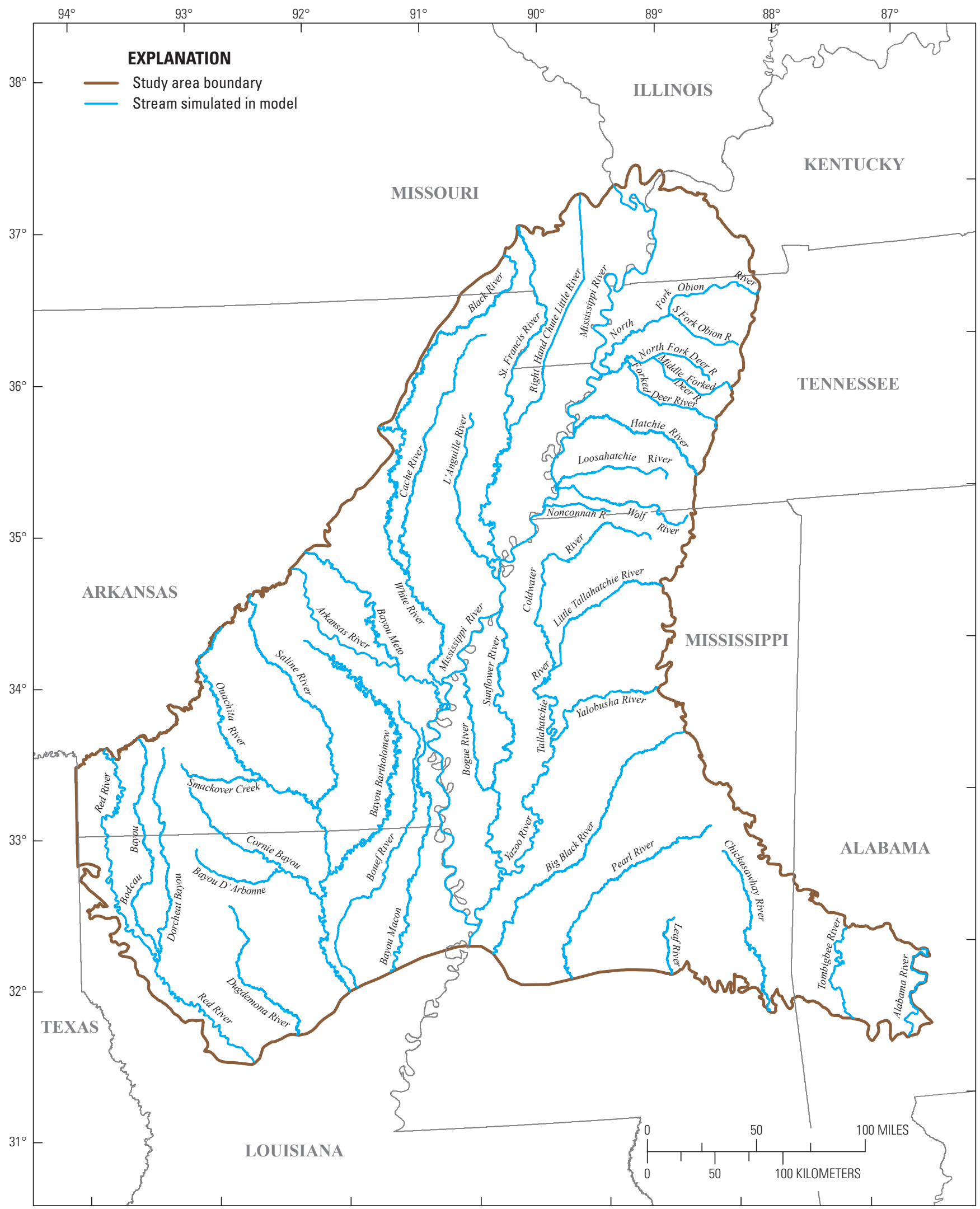

Base from U.S. Geological Survey digital data, 1:100,000

Figure 2. Streams simulated in the study area. 

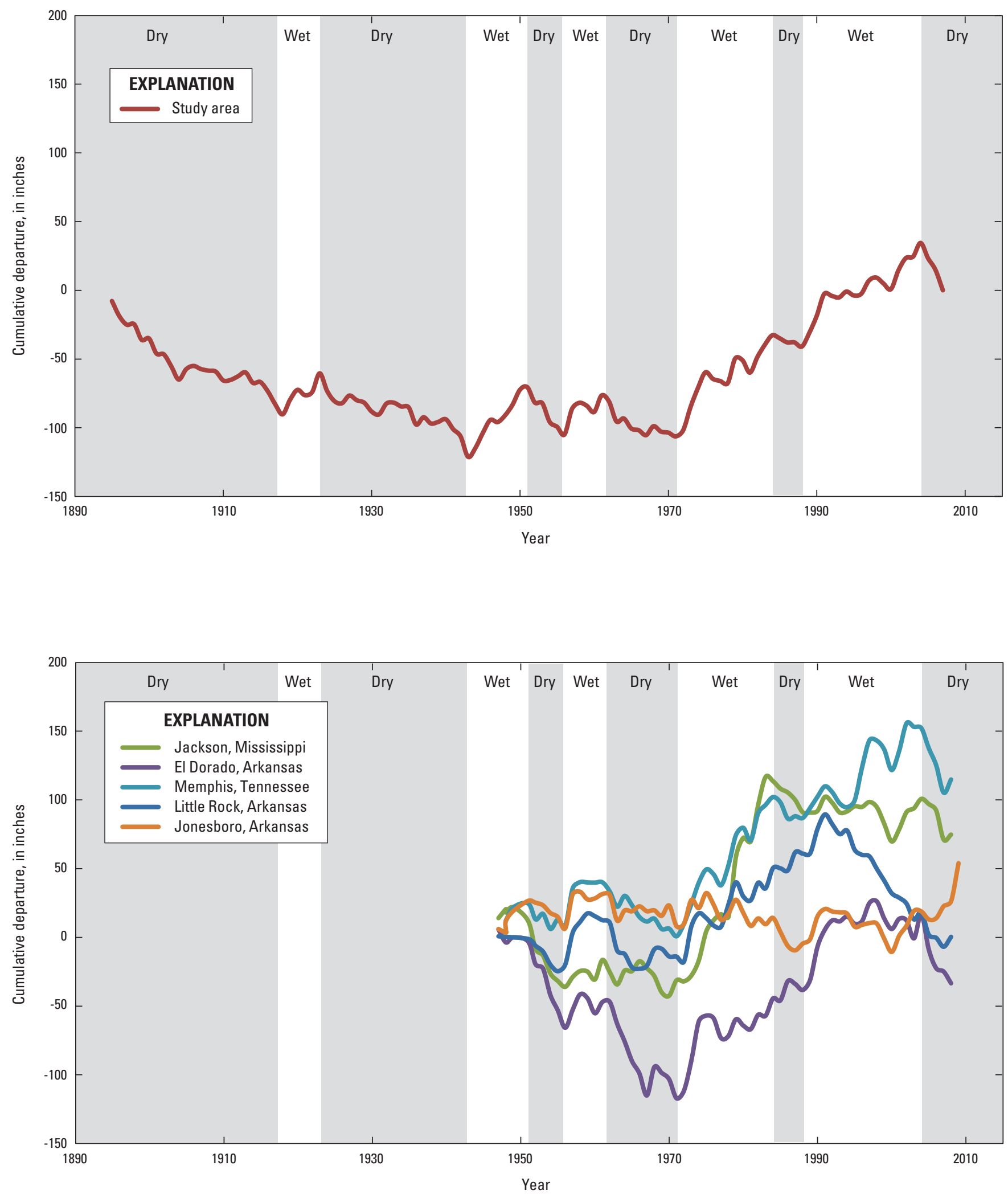

Figure 3. Cumulative departure from average precipitation within the study area and at selected locations, showing dry and wet periods for the study area. 


\section{Population}

Population density within the Mississippi embayment is greatest in four large urban areas. Based on 2000 U.S. Census data (Tele Atlas North American, Inc., 2008), 67 percent of the total population is located in urban areas. The most densely populated areas are Jonesboro, Arkansas, Monroe, Louisiana, Jackson, Mississippi, and Memphis, Tennessee (fig. 1). Population increased 2.4 percent in the study area from 2000 to 2005; the total population for 2005 was approximately 5.2 million (Tele Atlas North American, Inc., 2008). The increase in population overall and the movement of people from rural to urban areas have expanded the occurrence of large pumping centers, which can result in declining groundwater levels with measureable cones of depression.

\section{Land Use}

Land use in the Mississippi embayment is primarily agricultural. Cultivated cropland accounts for approximately 45 percent of the study area, forested land 38 percent, water 14 percent, and urban land 3 percent of the total area (U.S. Geological Survey, 2008b) (fig. 4). The greatest density of cropland lies within the area covered by the Mississippi Alluvial Plain (fig. 1). About 7 percent of the Mississippi Alluvial Plain is used for rice, 22 percent for cotton, 35 percent for soybeans, 5 percent for corn and wheat, 10 percent for pasture, and the rest for other crops or nonagricultural land (Stuart and others, 1996). The largest urban area is the city of Memphis, Tennessee (fig. 4), which covers about $280 \mathrm{mi}^{2}$ and historically has relied heavily on groundwater pumpage to meet municipal requirements.

\section{Water Use}

An estimated 12 million acre-ft/yr $(11 \mathrm{Ggal} / \mathrm{d})$ of groundwater was pumped in 2005 in the Mississippi embayment (U.S. Geological Survey, 2010a). Groundwater use for irrigation is the largest use, accounting for approximately 10 million acre-ft/yr ( $9 \mathrm{Ggal} / \mathrm{d})$ of groundwater pumped in 2000 from the Mississippi River Valley alluvial aquifer in Arkansas, Louisiana, Mississippi, and Missouri, and to a lesser extent in Illinois, Kentucky, and Tennessee (Maupin and Barber, 2005). In Arkansas, the largest user of groundwater in the Mississippi embayment, 93 percent of groundwater withdrawals in 2005 were for irrigation. Surface irrigation is the predominant application method in Arkansas, Louisiana, Mississippi, and Missouri (Hutson and others, 2004; Kenny and others, 2009). Groundwater pumping for irrigation is seasonal, beginning as early as April and extending through September in some years. Public supply and commercial/ industrial water use can be provided by groundwater and surface-water sources. Approximately 89 percent of public supply water use in Mississippi is provided by groundwater, compared to 34 percent in Arkansas and 49 percent in
Louisiana (Kenny and others, 2009). The estimated use of groundwater for public supply in Shelby County, Tennessee (location of Memphis, Tennessee) was over 200,000 acre-ft/yr $(180 \mathrm{Mgal} / \mathrm{d})$ in 2005 , and groundwater is the sole source for public supply in that county. Aquaculture is a large commercial business in Arkansas, Louisiana, and Mississippi. Of the total withdrawal of water for aquaculture use in these states, 82 percent is from groundwater (Kenny and others, 2009). Some of the larger users of water for industrial use in Arkansas, Louisiana, and Mississippi include those manufacturing paper products and chemicals (Johnson, 1993; Holland, 2007; Sargent, 2007). Arkansas and Mississippi use approximately 1.6 to 1.7 times more surface water than groundwater for industrial use in contrast to Louisiana, which uses over 10 times more (Kenny and others, 2009).

Groundwater use in the Mississippi embayment is reflected in the pumpage amounts used in the MERAS model. A brief description of the water-use compilation for the MERAS model is included in the Data Compilation section. For additional information see Clark and Hart (2009). Cumulative groundwater pumpage to 2007 from the Mississippi River Valley alluvial aquifer amounts to over 280 million acre- $\mathrm{ft}$ (enough to cover the entire study area in more than $5 \mathrm{ft}$ of water), or approximately 87 percent of the total cumulative amount pumped (fig. 5). The amount from the Mississippi River Valley alluvial aquifer is more than nine times that of the middle Claiborne aquifer, which is the second largest producer of groundwater in the Mississippi embayment. Cumulative groundwater pumping from the middle Claiborne aquifer makes up approximately 9 percent of the total cumulative amount, while combined pumping from remaining aquifers makes up 4 percent of the total cumulative amount.

\section{Geologic Setting}

The Mississippi embayment aquifer system lies within a plunging syncline with the axis primarily trending southward roughly parallel to the Mississippi River (Hart and others, 2008). The plunging syncline is a result of downwarping and rifting related to the Ouachita orogeny, which formed a deep catch basin for subsequent sedimentation. Downwarping and downfaulting proceeded further as a response to the weight of sediment accumulation (Hosman, 1996). This deep catch basin started infilling with Jurassic sediments, followed by Cretaceous marine deposits, and finally Cenozoic deposits, which constitute the main water-bearing units of importance within the Mississippi embayment. Cyclic invasions by transgressing and regressing seas through the Cretaceous and Tertiary Periods created the synclinal shape resulting in older rock units cropping out on the periphery of the embayment (Arthur and Taylor, 1998). The units exposed within the study area (fig. 6) are Cenozoic in age and consist primarily of Tertiary and Quaternary sands and gravels, silts, and clays. 


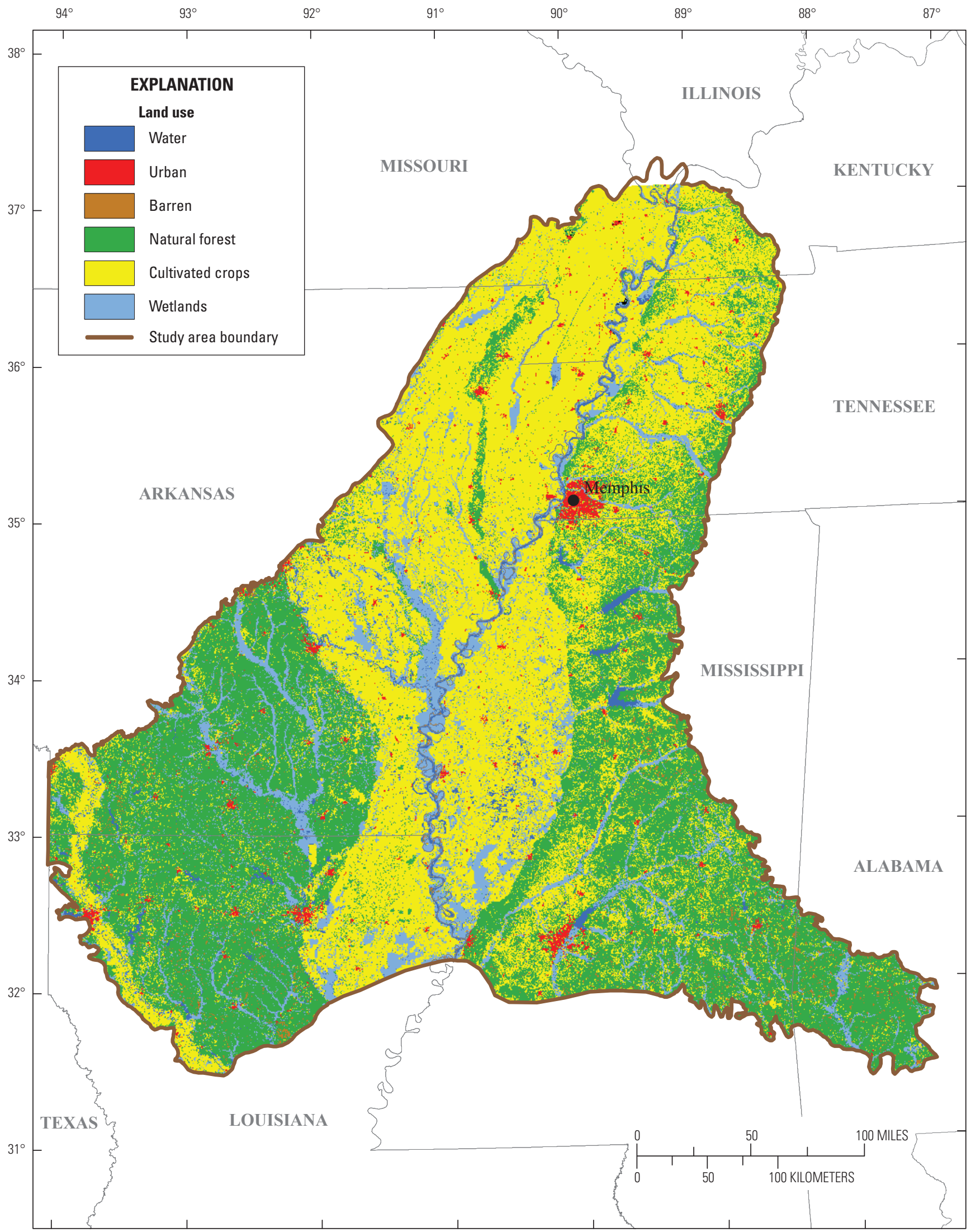

Base from U.S. Geological Survey digital data, 1:100,000

Figure 4. Land use within the Mississippi embayment. 


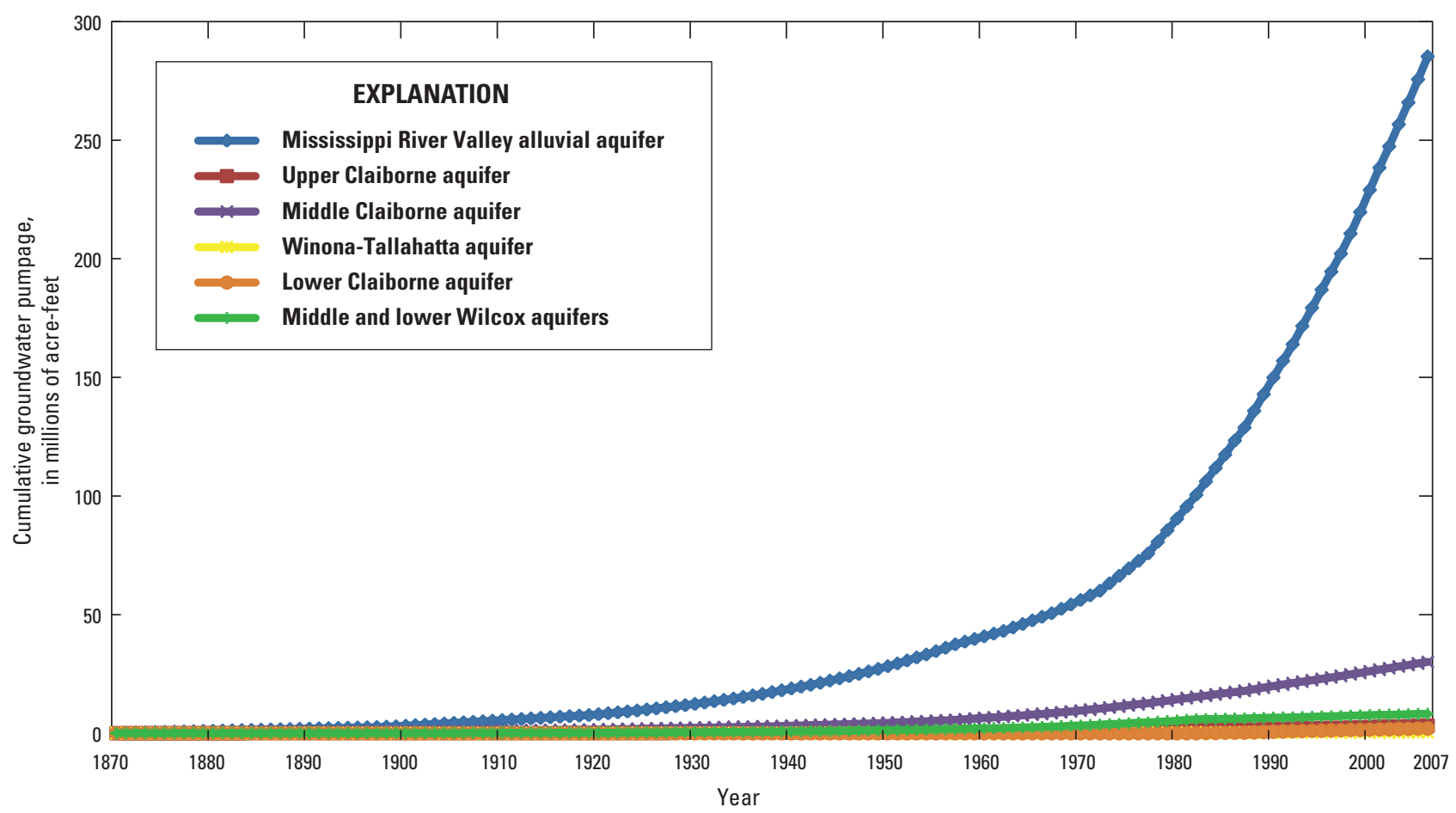

Figure 5. Cumulative groundwater pumpage by aquifer used in the Mississippi Embayment Regional Aquifer Study model.

\section{Hydrogeologic Units}

The primary hydrogeologic units simulated in the MERAS model include 10 units described by Hart and others (2008) and four additional minor hydrogeologic units described in Clark and Hart (2009). The units described by Hart and others consist of the Mississippi River Valley alluvial aquifer (hereafter referred to as the alluvial aquifer), the Vicksburg-Jackson confining unit, the upper Claiborne aquifer, the middle Claiborne confining unit, the middle Claiborne aquifer, the lower Claiborne confining unit, the lower Claiborne aquifer, the middle Wilcox aquifer, the lower Wilcox aquifer, and the Midway confining unit. Two of these primary hydrogeologic units are principal aquifers: the alluvial aquifer and the middle Claiborne aquifer (Renken, 1998). The alluvial aquifer is Quaternary and all other units simulated in the MERAS model are Tertiary (table 1). The alluvial aquifer consists primarily of gravel and sand deposits and generally contains groundwater under unconfined conditions. The middle Claiborne aquifer consists primarily of sand, silt, and clay deposits and generally contains groundwater under confined conditions. The minor hydrogeologic units described by Clark and Hart (2009) are the El Dorado confining unit, the El Dorado Sand, the Winona-Tallahatta aquifer, and the Old Breastworks confining unit. The El Dorado Sand is the lower part of the middle Claiborne aquifer in south-central Arkansas and north-central Louisiana. The El Dorado Sand is separated by a locally extensive confining unit, termed the El Dorado confining unit in this report, of up to $100 \mathrm{ft}$ thick. The WinonaTallahatta aquifer is the lower part of the lower Claiborne confining unit throughout much of Mississippi and includes the Tallahatta and Winona Formations. Additionally, throughout most of Arkansas and Louisiana, the middle and lower Wilcox aquifers are undifferentiated; however, in areas of Tennessee and Mississippi, the lower Wilcox aquifer may be separated into two units, the lower Wilcox aquifer and the Old Breastworks confining unit. The lower Wilcox aquifer consists of the lower part of the Wilcox Formation and includes the Old Breastworks Formation in Missouri and Tennessee. It is the lowermost aquifer in Tertiary rocks within the Mississippi embayment (Lloyd and Lyke, 1995) (table 1).

The hydrogeologic units and model framework, as part of this study, were a refinement of the framework developed by the Gulf Coast Regional Aquifer-System Analysis (GCRASA) program. Through the GCRASA program, 1,000 geophysical logs were used to develop the hydrogeologic framework of the Mississippi embayment, Texas coastal uplands, and the coastal lowlands aquifer systems (Hosman and Weiss, 1991) (approximately 300 geophysical logs of the 1,000 used were within the Mississippi embayment). The MERAS, focused on the Mississippi embayment area, used over 2,600 geophysical logs to develop the hydrogeologic framework (Hart and others, 2008; Hart and Clark, 2008). This approximately 3-year effort utilized multiple hydrologists in four States and resulted in substantial improvement in the resolution of the hydrogeologic units over previous studies. Additionally, all geophysical logs used in the interpretation of the model framework were archived and placed online (http://pubs.usgs.gov/sir/2008/5192/) for the benefit of studies that may want to continue refining the knowledge gained through the MERAS effort. The same nomenclature 

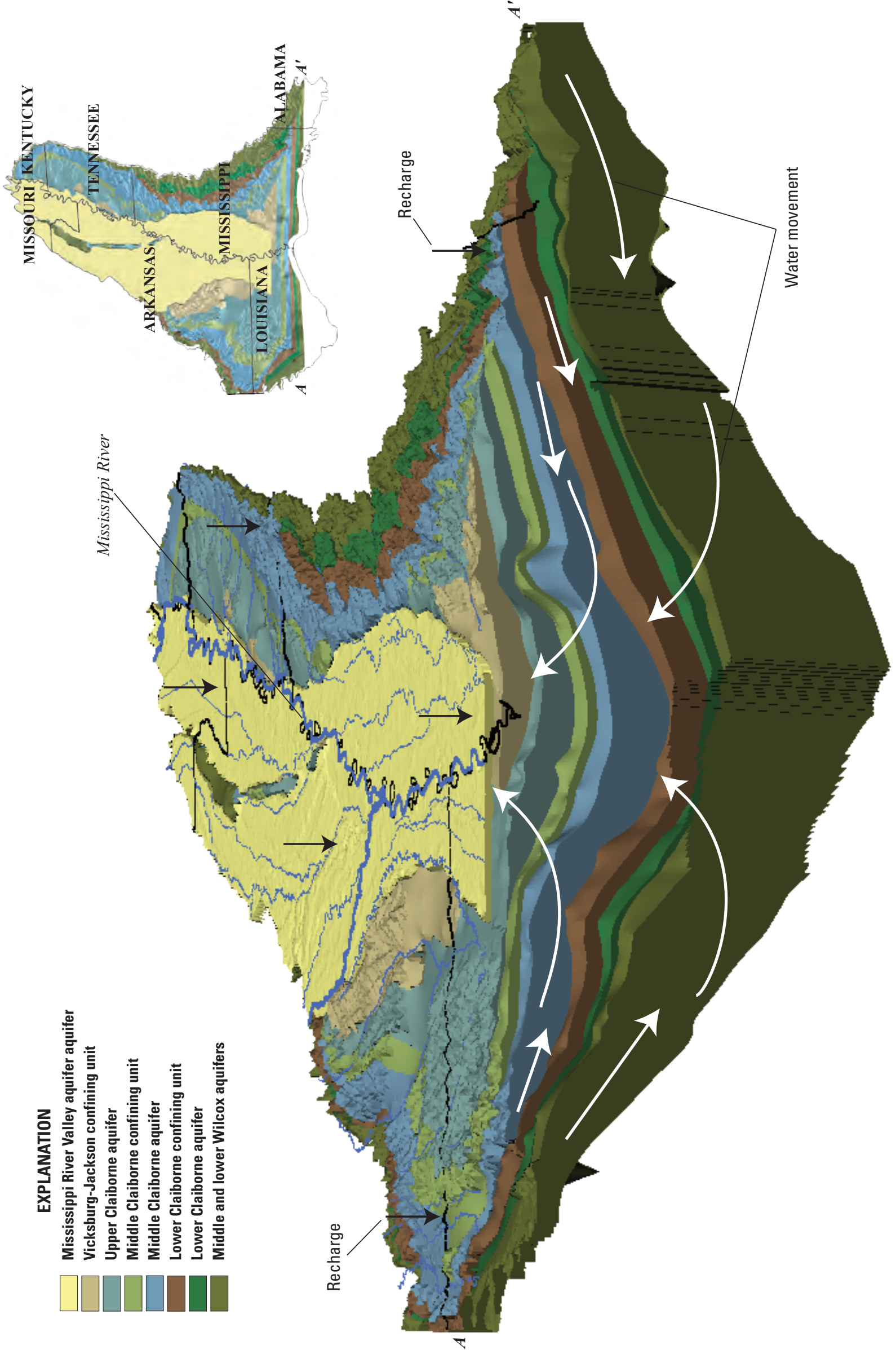

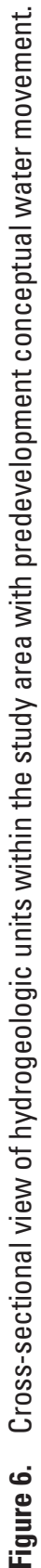




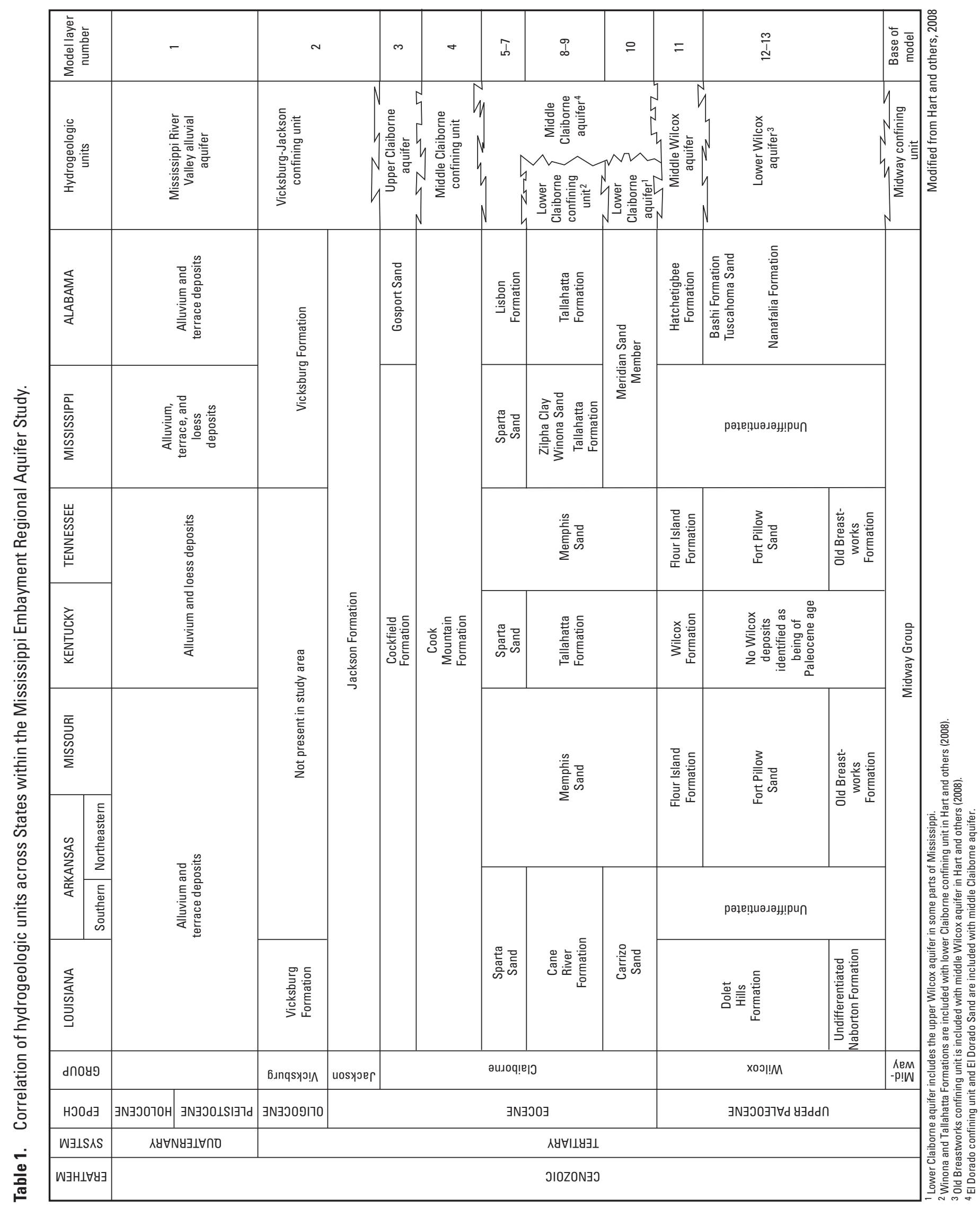


and hydrogeologic units were used between this study and the GCRASA study with an effort to adjust any inconsistencies between hydrogeologic units from the previous GCRASA study.

\section{Previous Investigations}

Previous investigations of groundwater flow in the embayment are numerous. Some early examples were the 1906 investigation of the underground waters of northern Louisiana (Veach, 1906) and a 1928 investigation of groundwater resources of Mississippi (Stephenson and others, 1928). The U.S. Geological Survey (USGS) began an effort in 1978 to "provide a regional understanding and assessment of the Nation's ground-water resources" (Bennett, 1979). This endeavor, known as the Regional Aquifer-System Analysis (RASA) Program, provided studies on the Nation's most important aquifer systems. The Mississippi embayment aquifer system was analyzed as part of the GCRASA study. The GCRASA study produced several USGS Professional Papers (Grubb, 1998; Hosman and Weiss, 1991; Weiss, 1992; Ackerman, 1996; Ryder and Ardis, 2002; Williams, 2001; Hosman, 1996; Martin and Whiteman, 1999; Arthur and Taylor, 1998) from several authors. The GCRASA compiled data and simulated groundwater flow using groundwater-flow models in three main parts: the Mississippi River Valley alluvial aquifer, the Mississippi embayment aquifer system, and the Gulf Coastal lowland aquifer system (U.S. Geological Survey, 2008a). Other reports summarize results of groundwater-flow simulations of parts of the Mississippi embayment including Reed (1972), Brahana and Mesko (1988), Fitzpatrick and others (1990), Mahon and Ludwig (1990), Sumner and Wasson (1990), McWreath and others (1991), Kilpatrick (1992), Mahon and Poynter (1993), Ackerman (1996), Arthur and Taylor (1998), Hays and others (1998), Arthur (2001), Brahana and Broshears (2001), McKee and Clark (2003), Stanton and Clark (2003), and Reed (2003).

\section{Methods Overview}

The primary method used to evaluate the conceptual groundwater flow of predevelopment and changes in postdevelopment groundwater flow, effects of climate variability, and a groundwater-monitoring network was the MERAS model (Clark and Hart, 2009). Groundwater-flow budgets were analyzed using the computer program ZONEBUDGET (Harbaugh, 1990). Additional analysis of the groundwaterflow system was through use of model scenarios to evaluate the effects of climate variability on groundwater levels. The scenarios extend the MERAS model simulation through 2037 and use forecasted precipitation based on frequency analysis of historic climate cycles. The computer program OPR-PPR (Tonkin and others, 2007) was used to demonstrate an evaluation of the relative importance of individual groundwater-level observations in a monitoring network in the middle Claiborne aquifer. Such monitoring networks are critical indicators of current, past, and future conditions of a groundwater resource.

\section{Numerical Model}

The construction and calibration of the MERAS model developed for this study are documented in Clark and Hart (2009). A brief description of the model is provided herein. The model was constructed using the modular three-dimensional (3D) finite-difference USGS MODFLOW-2005 code (Harbaugh, 2005) along with the preconditioned conjugate gradient solver (Hill, 1990). The model is subdivided into a set of discrete blocks in space and time. The blocks represent cells (with uniform horizontal spacing of 1 mile on a side and variable thickness) of porous material within which the hydraulic properties are the same. A set of finite-difference equations describes groundwater flow through each cell. These equations can be solved to simulate either equilibrium (steady-state) conditions or transient conditions, which simulate changes in stresses over fixed periods of time. The finite-difference grid is oriented north-south and consists of 414 rows, 397 columns, and 13 layers. The model simulates 137 years (1870-2007) of system response to stress divided into 69 stress periods. The first stress period is simulated as steady state to represent predevelopment conditions. Stress periods 2 through 27 are variable in length to reflect embayment-wide changes in groundwater withdrawals. Stress periods 28 (beginning in 1986) through 69 are each 6 months in length to reflect springsummer (April-September) and fall-winter (October-March) conditions related to irrigation (Clark and Hart, 2009). Areal recharge is applied throughout the MERAS model area using the MODFLOW-2005 Recharge Package (Harbaugh, 2005) and represents net recharge (defined as "the entry into the saturated zone of water made available at the water-table surface, together with the associated flow away from the water table within the saturated zone" (Freeze and Cherry, 1979)) because evapotranspiration (ET) was not explicitly simulated. Pumpage from irrigation, municipal, and industrial wells was simulated using the Multi-Node Well (MNW) Package (Halford and Hanson, 2002). The MNW Package allows simulation of flow in wells that are completed in multiple aquifers or model layers. There are 43 streams included within the MERAS model. Each stream in the model area was represented using the Streamflow-Routing (SFR) Package of MODFLOW (Prudic and others, 2004). The initial criterion for the inclusion of streams in the model was a mean annual flow of $1,000 \mathrm{ft}^{3} / \mathrm{s}$ or more. Other streams were added based on inclusion by previous model studies that demonstrated the interaction of the streams with surficial aquifers. The perimeter of the model area and the base of the flow system are represented as noflow boundaries. The perimeter of the model area represents an area where the hydrogeologic units do not exist or where flow into or out of the model area is assumed to be negligible. In model simulation the density of water was assumed 
to remain constant in time throughout the flow system. The downdip limit of each model layer is a no-flow boundary, which approximates the extent of water with less than $10,000 \mathrm{mg} / \mathrm{L}$ dissolved solids. The downdip limits of parts of the middle Claiborne and lower aquifers terminate north of the $10,000 \mathrm{mg} / \mathrm{L}$ dissolved solids line in an area that approximates the freshwater boundary delineated by Payne (1968).

\section{Data Compilation}

Data compilation for construction of the numerical groundwater-flow model used in this report began in 2006 (Clark and Hart, 2009). Data collection efforts were focused on six main components: (1) the hydrogeologic framework, (2) groundwater pumpage (water use), (3) hydraulic-head observations, (4) surface-water flows, (5) aquifer properties, and (6) net recharge. The database of information used to construct the hydrogeologic framework represented in the MERAS model includes over 2,600 geophysical logs (Hart and Clark, 2008; Hart and others, 2008). Compilation of the groundwater-pumpage data involved the collaboration of USGS personnel in seven states. This compilation included reported, estimated, and trend analysis of groundwater pumpage for as much as 100 years of data distributed to approximately 70,000 groundwater-well locations. Hydraulic-head data for the MERAS model consisted of over 55,000 groundwater-level altitudes from the USGS National Water Information System (http://waterdata.usgs.gov/nwis) and computation of 14 streamflow or stream-leakage values. Surface-water flows were required in the MERAS model for each of the 69 stress periods (spanning 137 years) at each point on the model boundary that a stream crosses into the active model area. Aquifer properties for each hydrogeologic unit were evaluated based on available aquifer test information, literature values for similar hydrogeologic units, or from previous groundwater-model studies. Net recharge to the outcrop areas of all hydrogeologic units was assigned by zone as a fraction of precipitation based on typical literature values and soil type or geology. These values were modified locally or regionally during calibration of the model. Additional information about the groundwater-flow model construction can be found in Clark and Hart (2009).

\section{Modifications to the Numerical Model}

The numerical model documented by Clark and Hart (2009) was modified slightly to improve the simulation of groundwater flow. These adjustments included decreasing the net recharge early in the simulation (predevelopment to the 1960s). This reduction in net recharge was necessary because it was noted in the model output that too much water as net recharge was applied to some aquifers, which caused an increase in water going into storage through time and higher than observed water levels early in the simulation. The simulated increase of water in storage early in the simulation is counter to the concept of the system being at steady state at that time. A possible justification for this change in the conceptual model of the groundwater system is that, prior to extensive development, recharge entered the aquifer and because water levels were likely within a few feet of land surface, ET removed much of the groundwater, maintaining steady-state conditions within the groundwater system. As pumping increased in the Mississippi embayment, water levels dropped and ET rates diminished, allowing greater amounts of net recharge to enter the aquifer. Because ET is not explicitly simulated in the MERAS model, the amount of net recharge was reduced during the early period of the simulation to account for the effect of ET on the groundwater system.

The modifications to the MERAS model for this report did not substantially change the calibration. For example, the root mean square error (RMSE) between all (55,786 comparisons) simulated and observed hydraulic heads is $23.24 \mathrm{ft}$ compared to $23.18 \mathrm{ft}$ in the original model (Clark and Hart, 2009). The RMSE for the alluvial aquifer observations is $16.94 \mathrm{ft}$ and for the middle Claiborne aquifer observations is $35.14 \mathrm{ft}$ in the modified model compared to $16.43 \mathrm{ft}$ and $35.78 \mathrm{ft}$ (Clark and Hart, 2009). Similar to the original model, simulated streamflow is underpredicted for 18 observations and overpredicted for 10 observations in the modified model. In the modified model, 4.2 percent of streamflow was gained from the groundwater system into a segment of the White River for 1998, the same as the original model (Clark and Hart, 2009). The water budgets for the two models were similar during the summer 2006. Total flows (sum of inflows or outflows) were 20.16 million acre-ft/yr in the modified model compared to 20.39 million acre-ft/yr in the original model (Clark and Hart, 2009).

\section{Development of the Hydrologic System}

The following sections describe the conceptual model of predevelopment groundwater flow and postdevelopment history of the hydrologic system. Anthropogenic effects of pumping and large-scale engineering of the hydrologic system has reversed groundwater flow in some areas.

\section{Predevelopment Conditions}

Groundwater-flow direction and magnitude in the study area are influenced by structural and depositional characteristics, surface-water bodies, and anthropogenic requirements. The synclinal shape of the Mississippi embayment creates natural recharge areas where the deeper, confined hydrogeologic units crop out along the east and west side of the study area (fig. 6). Conceptual predevelopment groundwater movement was into the recharge areas, downdip toward the axis of the synclinal structure, and discharged upward through overlying units (fig. 6). 
There are no known predevelopment (nonsimulated) potentiometric surfaces for the part of the alluvial aquifer simulated by the MERAS model. Williams and Williamson (1989) calculated an average depth to water of $25.7 \mathrm{ft}$ in 6,825 wells less than $150 \mathrm{ft}$ deep. Before development of the groundwater resource in the early 1900s, water levels in the alluvial aquifer were presumed to generally follow land surface and slope toward major rivers (Ackerman, 1989).

Predevelopment potentiometric surfaces for the middle Claiborne aquifer also are scarce, though some individual measurements exist from the first half of the 1900s. Reed (1972) presents a potentiometric surface of the middle Claiborne for 1886 "based on measurements made prior to extensive development." Anecdotal information and measured data indicate artesian conditions in the middle Claiborne aquifer existed in predevelopment and postdevelopment in some areas. One example of the potential for artesian conditions in the middle Claiborne aquifer (potentiometric head above land surface) is in the Holmes County area of Mississippi (fig. 1). Wells placed in the lower Claiborne aquifer in this area had water levels over $100 \mathrm{ft}$ above land surface in the 1940s to the 1960s (U.S. Geological Survey, 2010b).

Many streams dissect the Mississippi embayment, ranging in size from the Mississippi River, the second longest river in the United States, to numerous small streams (most being part of the Mississippi River system). Other major streams in the Mississippi embayment include the Arkansas, White, Ouachita, Red, Yazoo, and St. Francis Rivers (fig. 2). Conceptually, all streams in predevelopment time would be gaining (receiving water from the groundwater system) because there are no anthropogenic stresses to remove water from the system. Therefore, all net recharge entering the system increases the water level, causing flow toward the only exits in the model (because ET is not explicitly simulated), which are the streams. Simulated predevelopment conditions indicate that not all streams or all parts of streams are gaining (fig. 7). Streams in some areas, including the higher topographical areas along the eastern side of the MERAS model, are simulated as losing water to the groundwater system. The losing part of streams accounts for approximately 32 percent of the steady-state simulated stream cells. The average flow from these losing stream cells is 1,400 acre-ft/yr $\left(0.22 \mathrm{ft}^{3} / \mathrm{sec}\right)$. The average flow to gaining stream cells from the aquifer is $2,000 \mathrm{acre}-\mathrm{ft} / \mathrm{yr}\left(0.31 \mathrm{ft} /{ }^{3} \mathrm{sec}\right)$. This indicates that, in general, streams lose water to the aquifer in higher altitude areas and gain water from the aquifer downstream in lower altitude areas. The streams gain slightly more water than is lost because of additional net recharge that is added to the system. In terms of a predevelopment water budget, this means that the inflow of water from losing stream cells plus net recharge equals the outflow from gaining stream cells.

Predevelopment groundwater flow is represented in the MERAS model within a single steady-state stress period, assumed to be prior to 1870 . As with the conceptual model of predevelopment groundwater flow, water enters as net recharge to the alluvial aquifer (Quaternary sediments) or through outcrop areas for the other hydrogeologic units. Away from the outcrop areas, groundwater flow is primarily upward into overlying units, ultimately discharging to streams through the alluvial aquifer (fig. 6). The simulated groundwater-flow budget indicates that the largest predevelopment inflow to the system is net recharge to the alluvial aquifer (fig. 8). This inflow is balanced primarily by outflow to gaining streams. Net predevelopment recharge to the alluvial aquifer totaled $567,568 \mathrm{acre}-\mathrm{ft} / \mathrm{yr}$, almost six times more than the net predevelopment recharge to the Tertiary aquifers and confining units (table 1). Groundwater flow from the Tertiary system to the alluvial aquifer totaled an additional 160,649 acre-ft/yr. Most of the combined groundwater inflow to the alluvial aquifer of 728,217 acre-ft/yr was discharged to streams and a small amount (605 acre-ft/yr) discharged back into the Tertiary system.

\section{Postdevelopment Conditions}

Development of the groundwater system began just a few years after the end of the Civil War. Prior to the late 1800 s, most wells were developed in the Quaternary sands and gravels at depths ranging as much as $150 \mathrm{ft}$. Since that time, technological advances in deep well pumps and well-drilling technology allowed for the expansion of deep wells throughout the Mississippi embayment. As the necessity increased and costs decreased, plantations, cotton gins, ice factories, cotton-oil mills, and cotton factories justified the expenditure for deep wells. The importance of the deeper groundwater also began to be associated with the clean supply of potable water, or as Veatch (1906) described the "hygienic value of deep well waters." The use of deep wells became popular to avoid malaria and typhoid fever carried in shallow wells. Veatch (1906) also mentions the dual dependency of some early public water supplies on groundwater and surface water and the importance of lumber mills in the development of deep wells. As cities became more populated, the rapid development and increased fire risks required systems to quickly and efficiently deliver groundwater. Finally, the railroads and lumber industry, associated with rapid development, required large amounts of a steady groundwater supply (Veatch, 1906).

Agricultural activities have increased since the early 1920s and are important to the economy of the Mississippi embayment. Engler and others (1945) note commercial rice farming in the Grand Prairie area of Arkansas beginning in 1904. However, the increased agricultural activities have necessitated a greater need for groundwater withdrawals. Since the early 1900s, water levels in many wells within the alluvial aquifer in the Grand Prairie area (Arkansas, Prairie, and Lonoke Counties, Arkansas) have declined substantially (Schrader, 2008). A comparison of two potentiometric-surface maps of the alluvial aquifer in the Grand Prairie from 1929 and 2006 shows declines of as much as $43 \mathrm{ft}$ in the center of the cone of depression and an apparent decline of $100 \mathrm{ft}$ in central Lonoke County (fig. 9). 


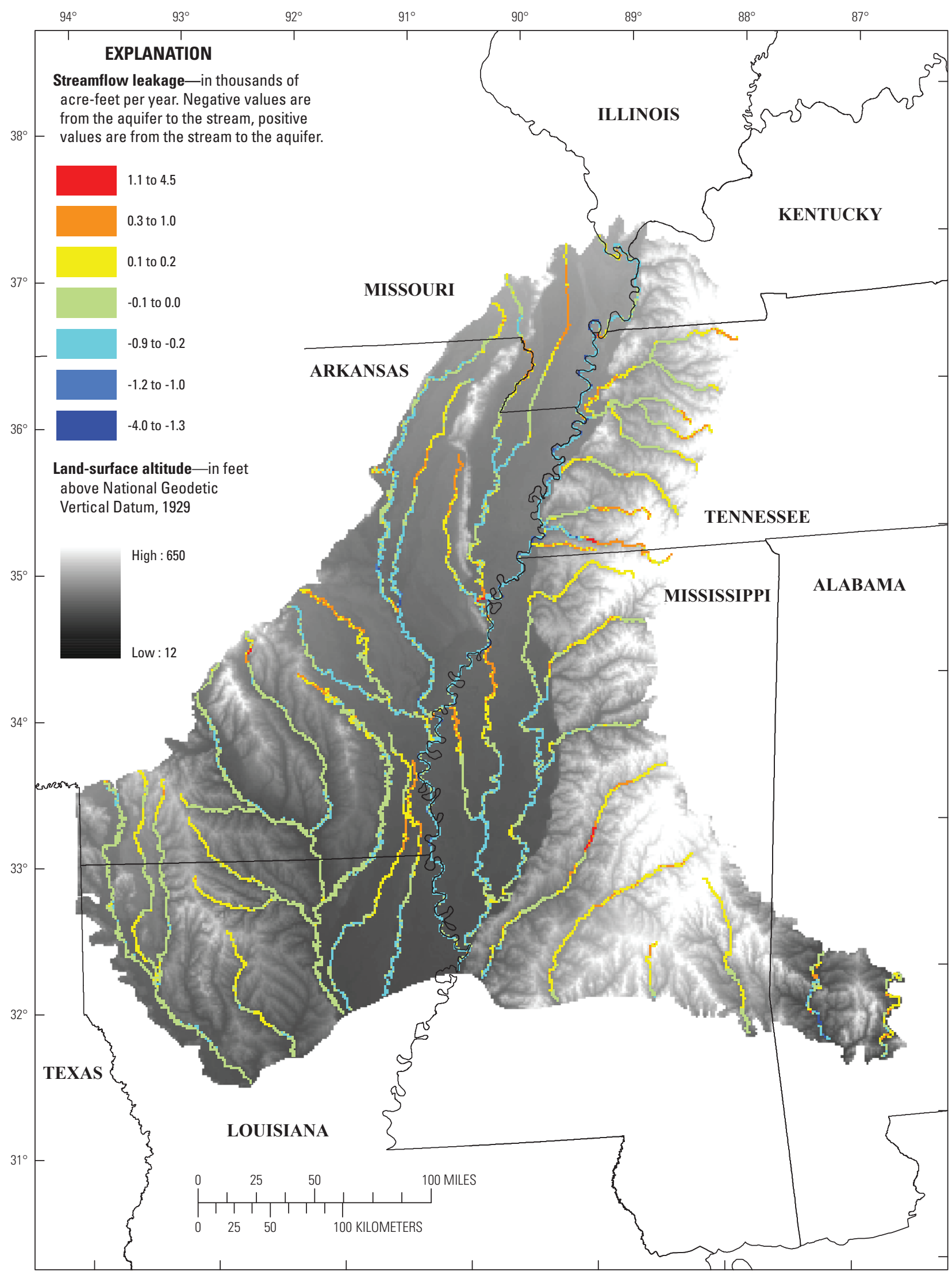

Base from U.S. Geological Survey digital data, 1:100,000

Figure 7. Simulated predevelopment streamflow leakage. 


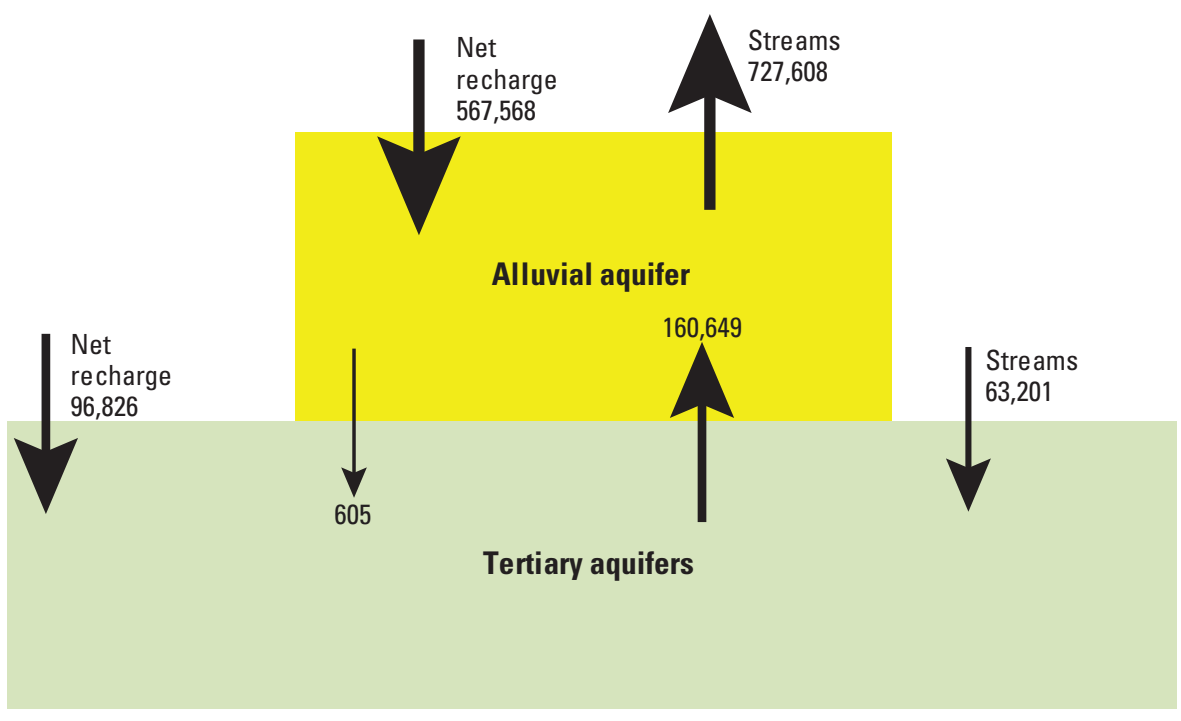

Figure 8. Predevelopment groundwater-flow budget of the alluvial and Tertiary systems, in acre-feet per year.

In areas of Mississippi, groundwater was considered abundant as late as the 1920s. Stephenson and others (1928) noted more than 50,000 acre-ft/yr (5 Mgal/d) supplied to three cities within Mississippi and the presence of six flowing wells. Stephenson and others (1928) also stated that groundwater within the alluvial aquifer in Mississippi "may be regarded as practically inexhaustible ..." with well yields as much as $4,000 \mathrm{gal} / \mathrm{min}$. This statement is in contrast to a quote from a recent Yazoo Mississippi Delta report which reads "as water levels continue to decline in the Central Delta, the production and efficiency of irrigation wells are being threatened" (Yazoo Mississippi Delta Joint Water Management District, 2008).

The largest urban center in the Mississippi embayment is the area of Memphis, Tennessee, with a 2000 population of 650,100 (U.S. Census Bureau, 2009). The first well in the middle Claiborne aquifer in the Memphis, Tennessee, area was completed in 1886 (Criner and Parks, 1976). This well was artesian at that time. Criner and Parks (1976) also state that "Pumpage from [the middle Claiborne] aquifer in 1975 was about $188 \mathrm{Mgal} / \mathrm{d}$ which is about twice that in 1950, five times that in 1920, and ten times that in 1890."

Groundwater resources of the Mississippi embayment have been tapped for human use for over 100 years. Through this period, changes in technology and agricultural practices have affected the natural groundwater flow and the interaction with surface-water bodies in the area (fig. 10). As the groundwater resource was developed for anthropogenic uses, agricultural demands for groundwater irrigation from the alluvial aquifer and municipal and industrial demands for groundwater from the middle Claiborne aquifer created large cones of depression in some areas. These cones of depression have resulted in a change in the direction of net discharge so that the postdevelopment flow is now downward (fig. 10). The simulated groundwater-flow budget indicates that the largest postdevelopment inflow to the system is net recharge to the alluvial aquifer (fig. 11). Net postdevelopment recharge to the alluvial aquifer totaled 2,513,094 acre-ft/yr, over six times more than the net postdevelopment recharge to the Tertiary aquifers and confining units (table 1). Groundwater flow from the alluvial aquifer to the Tertiary system totaled $501,682 \mathrm{acre}-\mathrm{ft} / \mathrm{yr}$.

Streams within the Mississippi embayment generally have low gradients, and some have been hydrologically altered (channelized, impounded, and diverted) to suit agricultural purposes (Justus, 2003). In some instances, impoundments may limit streamflow downstream from the impoundment so that little if any water is available to recharge the aquifer. Surface-water diversions have been suggested as a means to alleviate the stress on the underlying aquifers. Projects such as the Grand Prairie Area Demonstration Irrigation Project have been established by the Memphis District, U.S. Army Corps of Engineers (USACE) (U.S. Army Corps of Engineers, 2009) to "protect and preserve the alluvial and Sparta aquifers." The project aims to provide additional water to already established tailwater recovery systems and on-farm reservoirs through a series of canals to supplement irrigation needs (U.S. Army Corps of Engineers, 2009).

\section{Groundwater Availability, a Water- Budget Perspective}

Groundwater availability comprises many factors. These factors include water law, regulations, economics, infrastructure, quality of water, and quantity of water (U.S. Geological Survey, 2002). The water law factor involves the legality of pumping water that may affect a neighboring farm, State, or country. The regulation factor may be imposed where pumping from a water resource could negatively impact the sustained use of the resource by causing unacceptable environmental, 

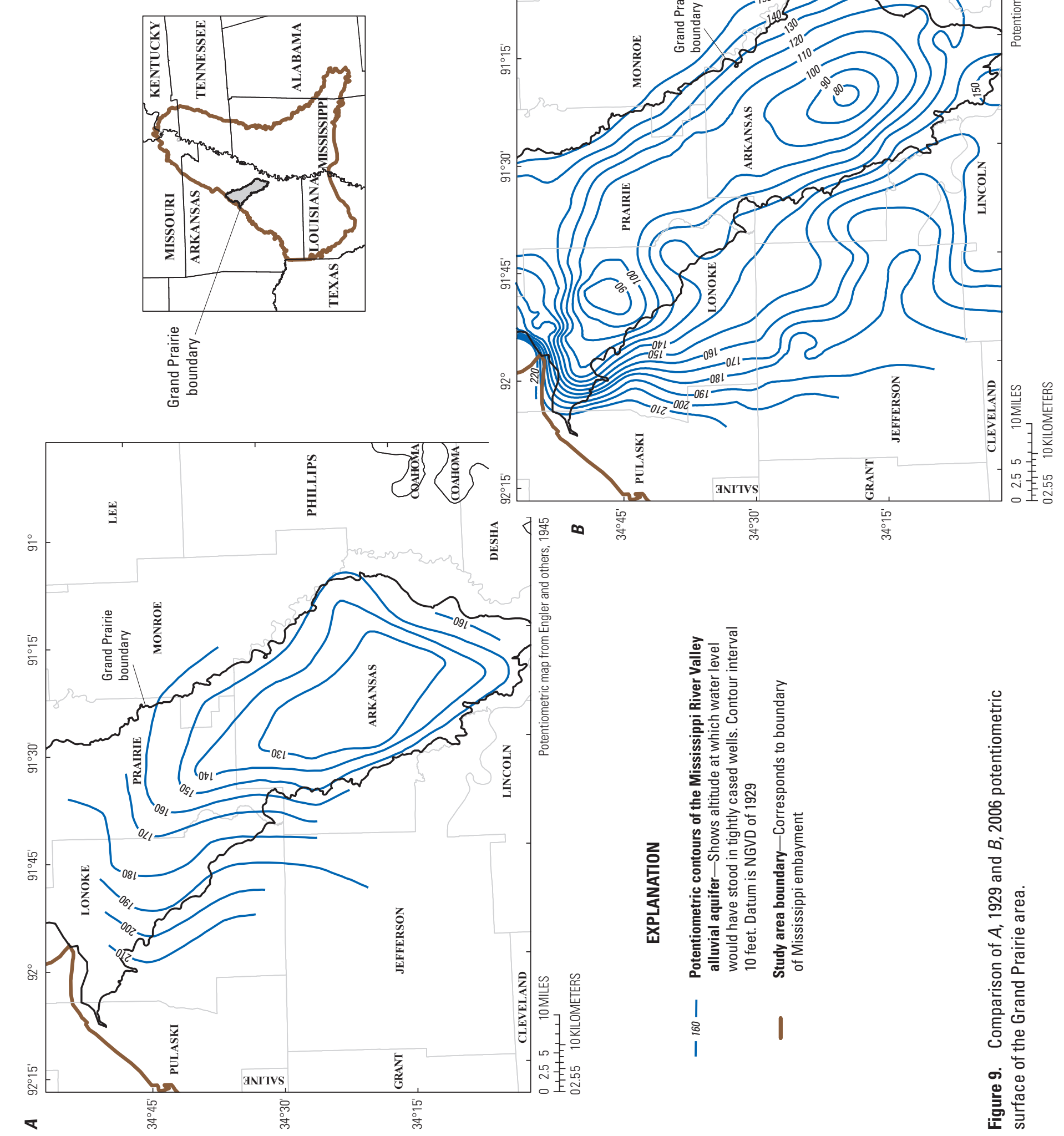


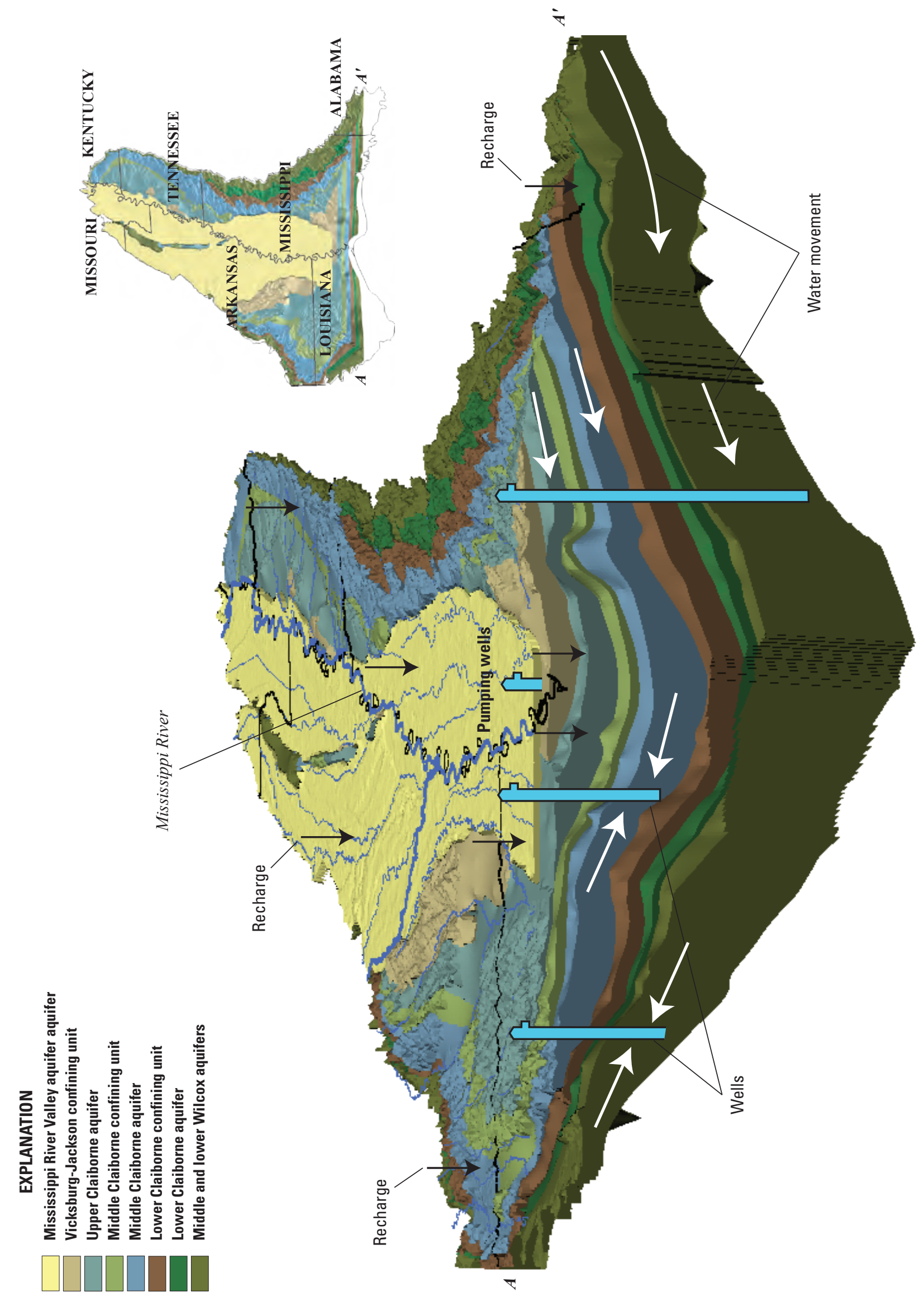




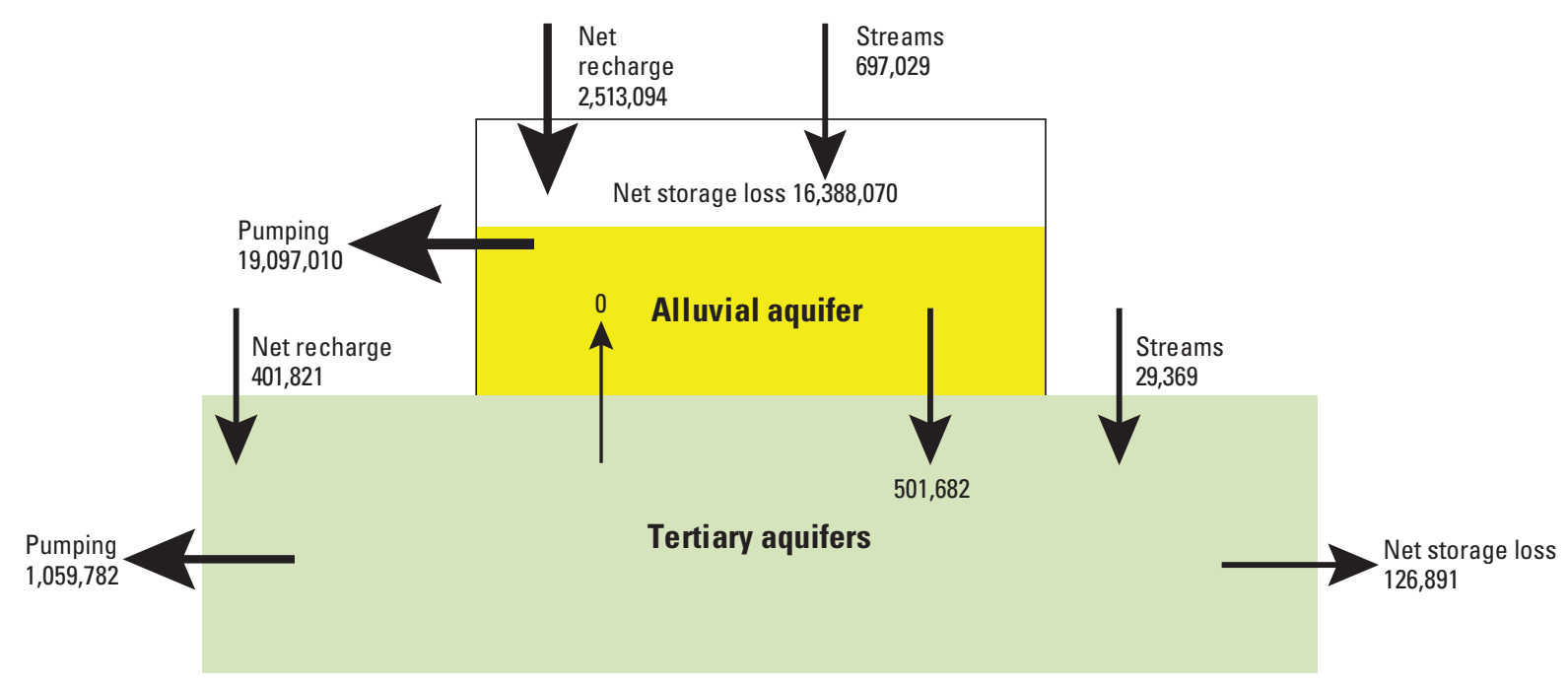

Figure 11. Postdevelopment groundwater-flow budget of the alluvial and Tertiary systems in acre-feet per year.

economic, or social consequences. The infrastructure factor determines if a suitable network of pumps, pipes, valves, and power sources exist to transport the water for the required application. The acceptable quality of water is dependent on the intended use, rather it be for human consumption or other application such as industrial uses. Finally, the quantity factor affects the availability by the determination of how much water is actually present, regardless of the previous factors. The intent of the analysis in this Professional Paper is to examine the quantity factor or the amount of groundwater available in the Mississippi embayment. Groundwater availability in the MERAS is changing because of natural and anthropogenic events such as precipitation, land use, stream channelization, and pumping.

The groundwater budget indicates changes in storage, flow into (inflows), and out of (outflows) the aquifer system simulated by the MERAS model from the predevelopment period (1870) to 2007 (fig. 12) (Clark and Hart, 2009). Negative rates indicate outflows from the groundwater system, and positive rates indicate inflows to the groundwater system. In the latter part of the simulation (beginning in 1986), each stress period represents a 6-month time period of alternating spring/summer and fall/winter (fig. 12A). These seasonal stress periods were designed to simulate the growing season when water is pumped for irrigation and the winter season when most irrigation wells are not pumping. Annual averages, rather than seasonal, of all groundwater-flow components are shown in figure $12 B$.

\section{Regional Water Budget}

Total net recharge and discharge (sum of inflows or outflows) for the model ranged from about 0.66 million acre-ft/yr during predevelopment to 20.16 million acre-ft/yr by the end of the simulation (final simulated irrigation period in summer 2006). During predevelopment, the aquifer system was considered to be at steady state, resulting in a net change of zero in aquifer storage. Early in the model simulation (18701920s), the primary components were simulated as outflow from stream leakage and inflow from net areal recharge. As pumpage increased through time, water that would otherwise flow to streams reversed and net stream leakage became an inflow to the system. Net areal recharge increased through the first 93 years of the simulation but dropped in dominance since the 1980s because of the increase in flow from aquifer storage. The largest reversals began in the mid 1980s, but indications of the reversal began in the early 1960s when a trend in loss of streamflow leakage as discharge and the first consistent inflow from storage began (fig. 12A). The seasonality of irrigation produces large net pumping values during the spring/summer stress periods, alternating with small net pumping values in the fall/winter stress periods (fig. 12A). Pumping from wells became the largest outflow component of the water budget with a net rate of 20.16 million acre-ft/yr (10.65 million acre- $\mathrm{ft} / \mathrm{yr}$ annual average) at the end of the model simulation in summer 2006. The large pumpage amounts are offset primarily by movement of water from storage into the aquifer. In the fall/winter stress periods, the net storage is reversed to replenish some of the storage capacity that was lost during the spring/summer pumping. The net change in storage was negative (water removed from storage), as reflected by the measured mean annual decline of water levels in some areas of the alluvial aquifer from 0.5 to $1.0 \mathrm{ft} / \mathrm{yr}$ from 1982 to 2006 (Schrader, 2008).

The storage component of the groundwater budget is important because the values of storage indicate the amount of water withdrawn from or added into the aquifers. The cumulative storage for aquifers simulated in the MERAS model (fig. 13) indicates overall depletion of 140 million acre- $\mathrm{ft}$ (equivalent to $2.8 \mathrm{ft}$ of water covering the entire study area) and depletion from the alluvial aquifer of 149 million acre- $\mathrm{ft}$ 

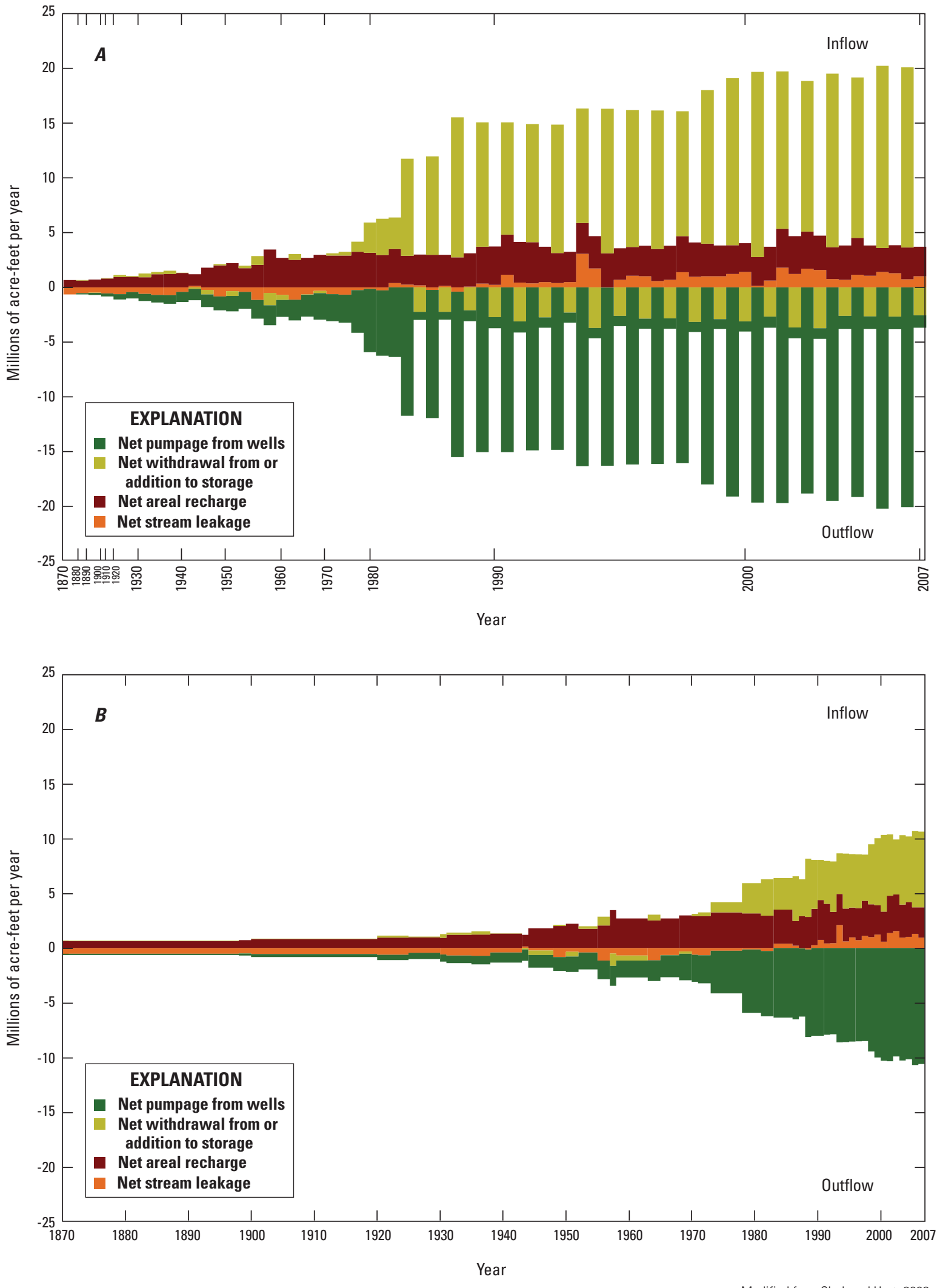

Figure 12. Groundwater-flow budget of the MERAS model $A$, seasonal after 1986, spring/summer depicted by large net pumpage and fall/winter depicted by small net pumpage; $B$, average annual. 


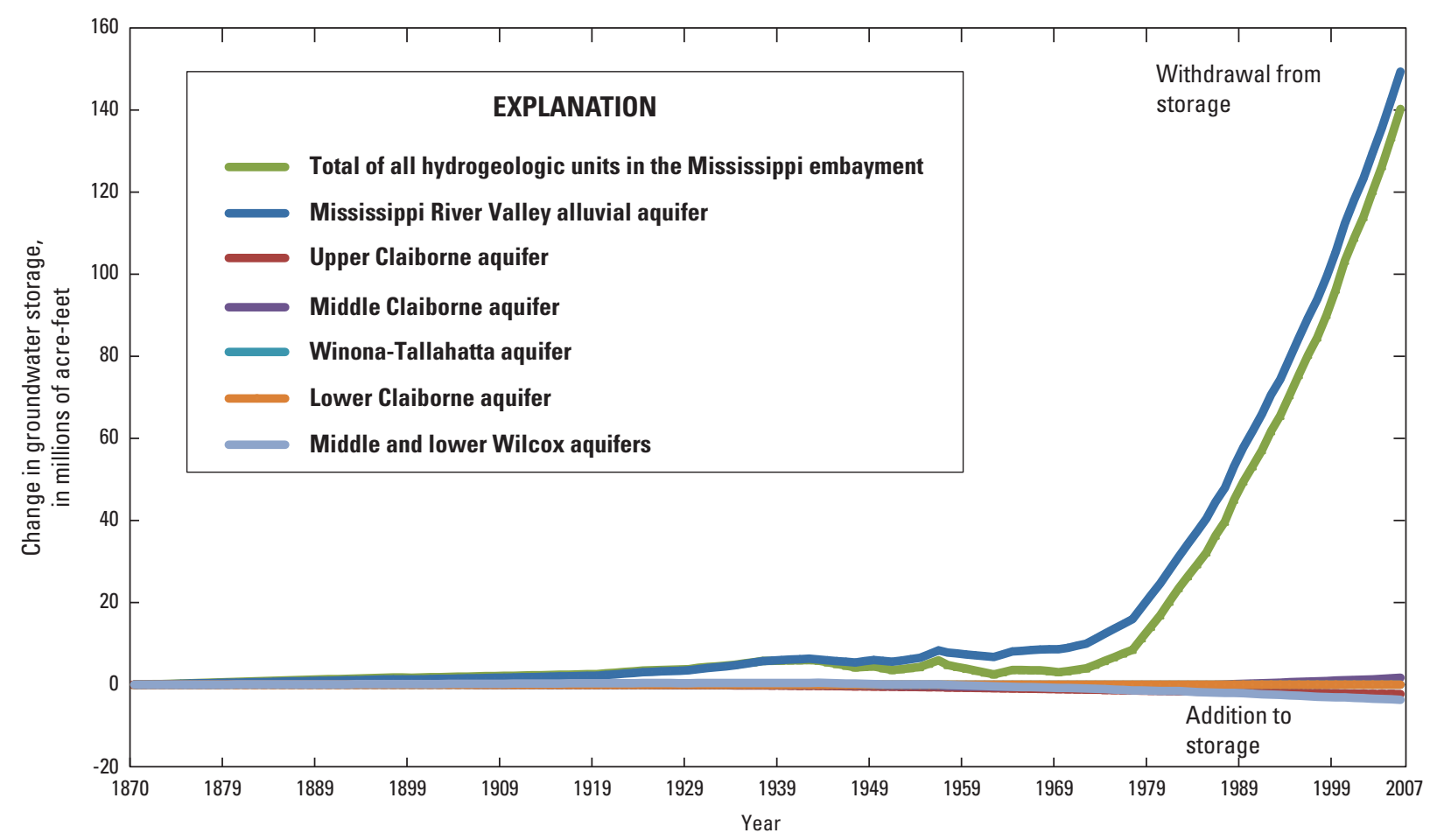

Figure 13. Cumulative change in groundwater storage by aquifer.

from predevelopment to 2007. The difference in overall depletion compared to depletion in the alluvial aquifer originates from additions of water from confining units not shown in figure 13. An estimate of the volume of freshwater stored in the alluvial aquifer can be made by calculating the thickness of the saturated zone (simulated spring 2007 water table minus bottom of the alluvial aquifer from the MERAS model) and multiplying by the specific yield (ranging from 0.1 to 0.3 in the MERAS model; Clark and Hart, 2009). This calculation results in a value of approximately 536 million acre- $\mathrm{ft}$ (equivalent to $10.7 \mathrm{ft}$ of water covering the entire study area) of water stored in the alluvial aquifer. The amount of water removed from aquifer storage is approximately 26 percent of the amount stored only in the alluvial aquifer. Alley (2007) notes "reported estimates of the volume of recoverable ground water in storage should be viewed with caution. Efforts to link such estimates with ground water availability may be highly misleading unless the full effects of ground water development are considered..." Therefore, the amount of water stored in the alluvial aquifer stated here is used to gain perspective on the quantity of water pumped from aquifers in the Mississippi embayment. It is unrealistic to assume that all water stored in the aquifers in the Mississippi embayment may be removed by pumping. To do so would substantially affect the performance of wells (the efficiency of pumping is reduced as water levels decline) and flow to streams, and would likely affect water quality.

In the Mississippi embayment, groundwater pumping has produced water-level declines across large areas. The change in water level from the predevelopment condition was calculated using the simulated water level of the alluvial and middle Claiborne aquifers. The water levels representing the predevelopment conditions for the alluvial and middle Claiborne aquifers were subtracted from the respective water levels at the end of each stress period. The time lapse result of this calculation may be seen in an animation at http://gallery. usgs.gov/videos/330 and http://gallery.usgs.gov/videos/331. The result of the last (spring of 2007) stress period of the simulation is shown in figure 14. Changes in the water level in the alluvial aquifer are noticeable throughout Arkansas and parts of Mississippi; by 2007, 0.7 percent of the alluvial area $\left(216 \mathrm{mi}^{2}\right)$ exhibited declines of more than $100 \mathrm{ft}$ (figs. $14 A$ and 15). Changes in water level in the middle Claiborne aquifer are more dramatic than changes in the alluvial aquifer, with over 13.3 percent of the aquifer area $\left(7,529 \mathrm{mi}^{2}\right)$ exhibiting water-level declines of over $100 \mathrm{ft}$ by 2007 (figs. 14B and 15). The largest declines of over $300 \mathrm{ft}$ in water level in the middle Claiborne aquifer occur in southern Arkansas and northern Louisiana (fig. 14B). The animations and figures 14 and 15 also demonstrate differences in confined and unconfined aquifers. Most areas within the middle Claiborne aquifer boundary are simulated as confined and, therefore, given a relatively small amount of pumping compared to the alluvial aquifer, water levels decline dramatically. However, because of the smaller amounts of removed water and the confined nature of the aquifer, if pumping ceased in these areas, a rebound of water levels would be likely. This is the situation in southern Arkansas where a concerted effort to reduce pumping has resulted in water-level increases of almost $50 \mathrm{ft}$ since 2004 in the middle Claiborne aquifer (Friewald and Johnson, 2007). 


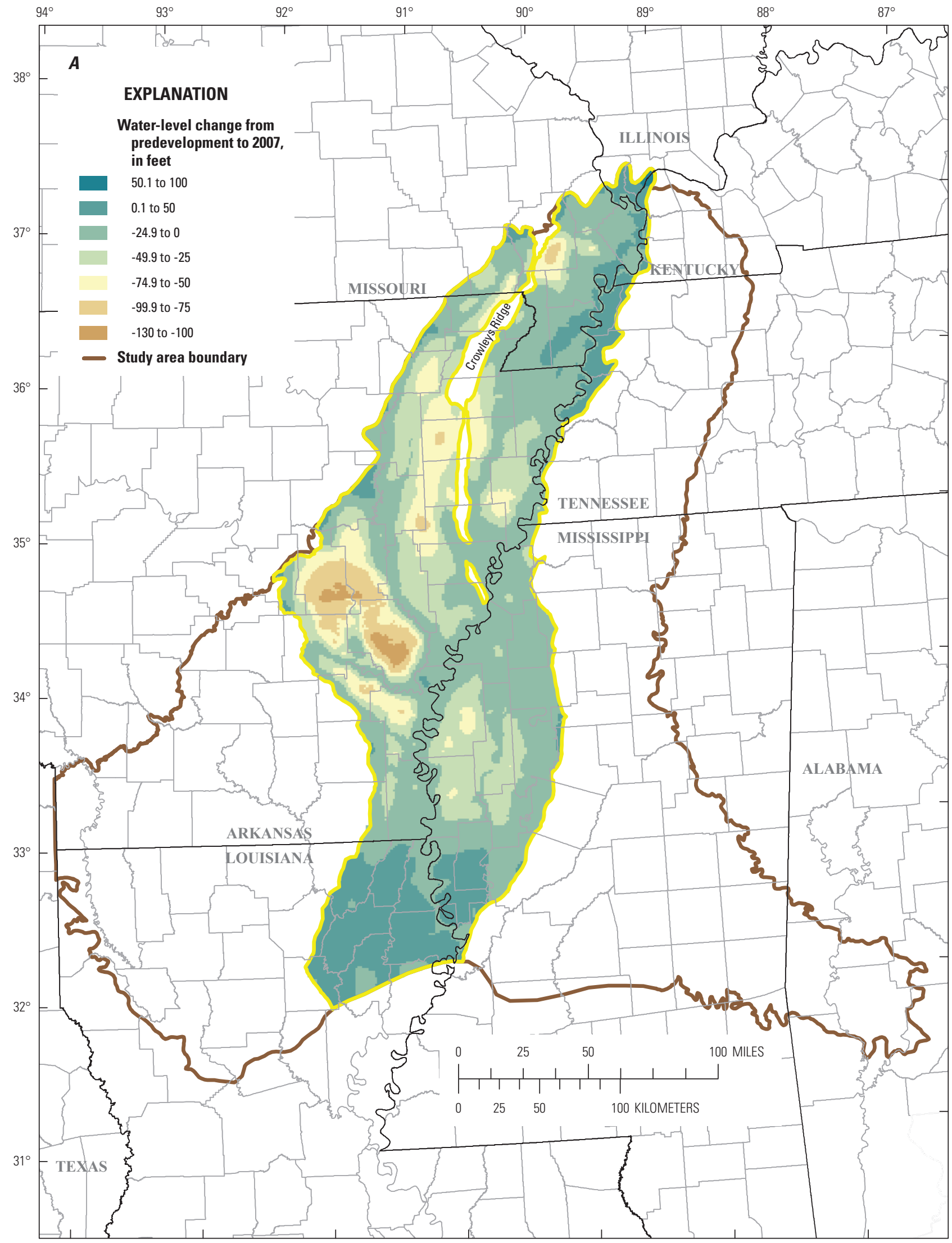

Base from U.S. Geological Survey digital data, 1:100,000

Figure 14. Water-level change from predevelopment to 2007 in the $A$, Mississippi River Valley alluvial aquifer and $B$, the middle Claiborne aquifer. 


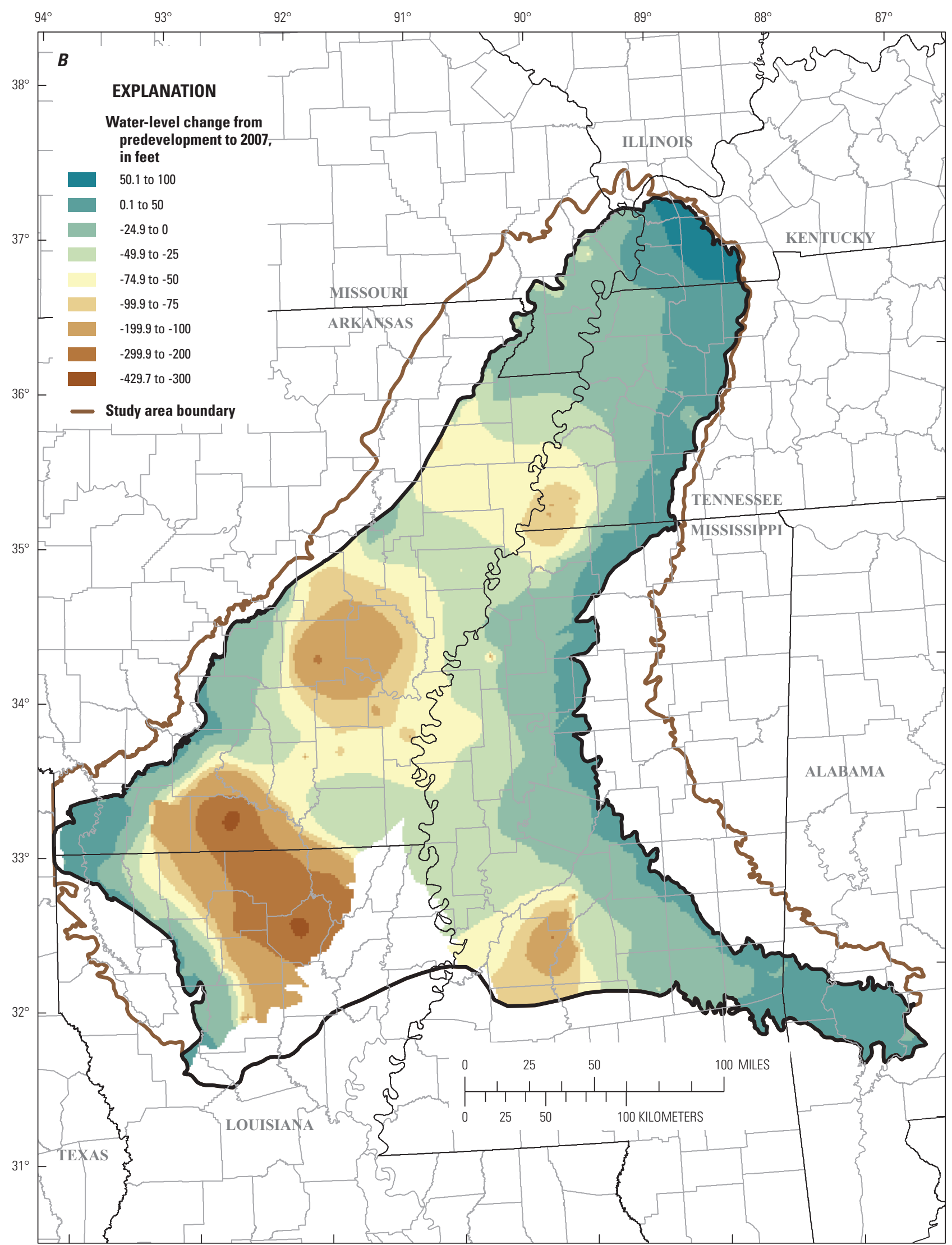

Base from U.S. Geological Survey digital data, 1:100,000

Figure 14. Water-level change from predevelopment to 2007 in the $A$, Mississippi River Valley alluvial aquifer and $B$, the middle Claiborne aquifer.-Continued 


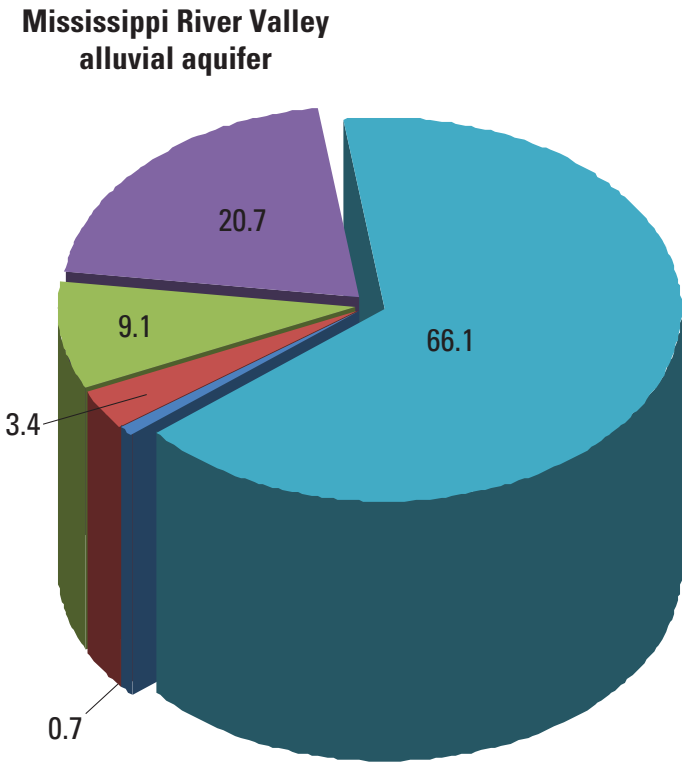

EXPLANATION

Percent of area of water-level decline
from predevelopment to 2007, in feet
Greater than 100
76 to 100
51 to 75
25 to 50
Less than 25

Middle Claiborne aquifer

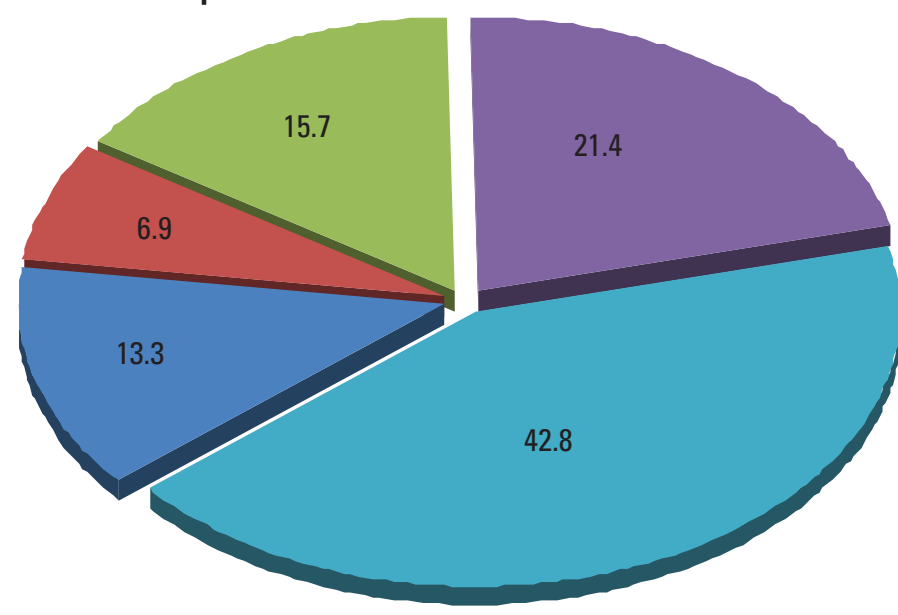

The thickness of the pie chart shows the relative amount of water pumped from each aquifer. The diameter of the pie chart indicates the relative areal extent of each aquifer. Percentages in pie charts may not total 100 percent because of rounding.

Figure 15. Percent area for water-level change groups from predevelopment to 2007 in the Mississippi River Valley alluvial aquifer and the middle Claiborne aquifer.
The reverse is typically true of unconfined aquifers, like the alluvial aquifer, in that although pumping has not resulted in water-level changes as great as those seen in the middle Claiborne aquifer, much more water has been removed. Therefore, if pumping ceased in the alluvial aquifer, a much longer period of time would be required to replenish the aquifer.

The pattern of simulated groundwater flow in 2006 (fig. 10) was in many ways a reversal of the predevelopment flow conditions (fig. 6). Whereas much of the inflow to the system in postdevelopment was still through net recharge to the alluvial aquifer and the outcrop areas of the several hydrogeologic units, the flow was no longer upward to the alluvial aquifer. Groundwater flow during the summer 2006 was primarily downward to offset demand from pumping from the Tertiary system.

\section{Principal Aquifer Water Budgets}

The groundwater-flow budgets of the alluvial and middle Claiborne aquifers were extracted from model output to evaluate groundwater flow at the aquifer scale (figs. 16 and 17). The groundwater-flow budget of the alluvial aquifer (fig. 16) appears almost identical in shape and magnitude to the diagram of the groundwater-flow budget for the overall system (fig. 12). This is because most water movement within the system is in the alluvial aquifer. Subtle differences include less pumpage during fall/winter stress periods and the inclusion of net flow to and from other aquifers in the MERAS model. Net vertical or horizontal flow into the alluvial aquifer from the other aquifers occurs primarily in the early part of the simulation period (prior to about 1960). The pattern of flow into the alluvial aquifer is also demonstrated in figure 6 that shows flow from most hydrogeologic units into the alluvial aquifer during predevelopment time. Net vertical or horizontal groundwater flow from other aquifers into the alluvial aquifer reversed and removed water from the alluvial aquifer in the 1980s (fig. 16B). One of the largest stream inflow events occurred in 1993, which corresponded to widespread flooding in the Mississippi River system. Whereas pumping from the alluvial aquifer (fig. 16A) is shown to increase dramatically from 1983 to 1986 , this was actually the transition from annual averages of pumping in early stress periods to 6-month seasonal pumping in the last 20 years of the simulation. For example, during a given summer stress period, an average of 20 million acre-ft/yr may be pumped over a 6-month irrigation season. During the other 6 months of the year, pumping is negligible (assume zero for this example). Therefore, the annual average value of pumping would be 10 million acre-ft/yr.

A comparison of groundwater-flow budgets indicates substantially less water in the middle Claiborne aquifer (fig. 17) than in the alluvial aquifer (fig. 16). While groundwater pumped out of the alluvial aquifer is derived primarily from storage (up to 70 percent, fig. 16), pumpage out of the middle Claiborne aquifer is derived primarily from other aquifers (up to 15 percent from the alluvial aquifer), followed by storage 

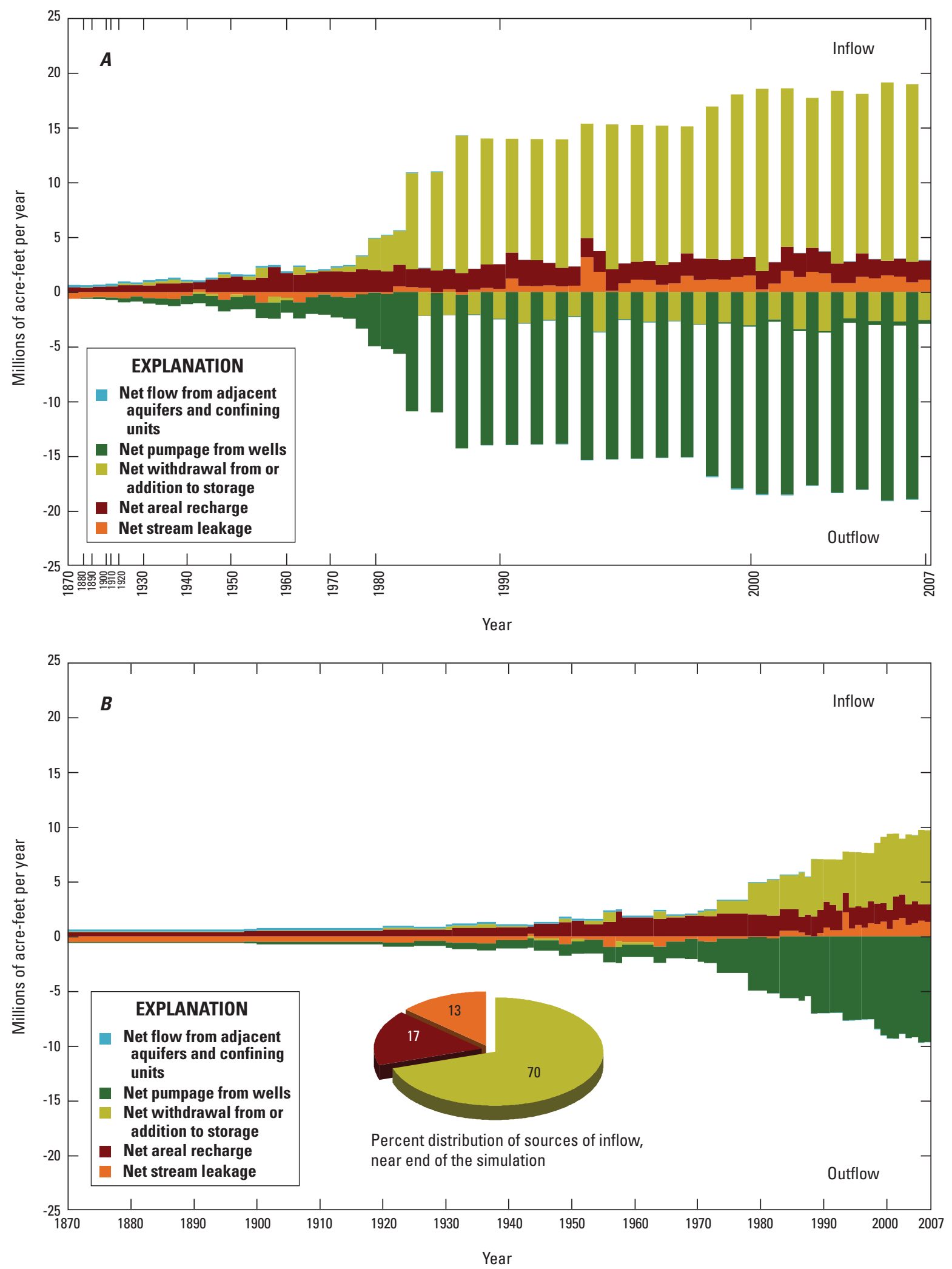

Figure 16. Groundwater-flow budget of the alluvial aquifer $A$, seasonal after 1986, spring/summer depicted by large net pumpage and fall/winter depicted by small net pumpage; $B$, average annual. 

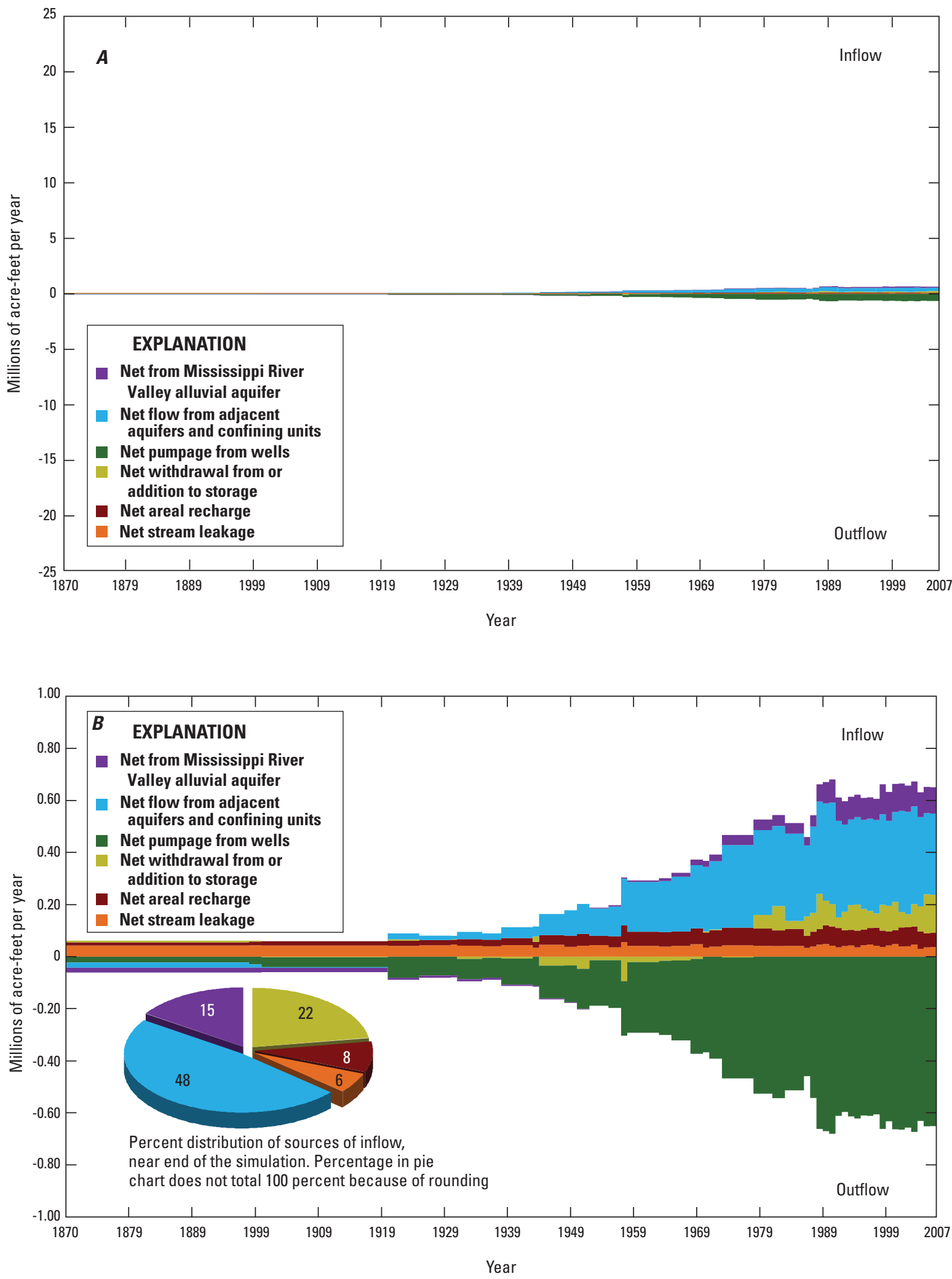

Figure 17. Groundwater-flow budget of the middle Claiborne aquifer. 
and net areal recharge. Early in the simulation period, water was derived primarily from net areal recharge and stream leakage. Discharge from the middle Claiborne aquifer during this early period was because of pumping from the middle Claiborne aquifer, flow to the alluvial aquifer, or flow to other aquifers. Beginning in the 1950s, discharge from the middle Claiborne aquifer to the alluvial aquifer was reversed such that flow was induced from the alluvial aquifer to the middle Claiborne aquifer (fig. 17).

\section{Local Area Water Budgets}

Spatial variability in groundwater availability exists within the Mississippi embayment, even within the same aquifer. Spatial variability of groundwater budgets and interactions between the alluvial and middle Claiborne aquifers and interactions between the middle Claiborne aquifer with other minor units were evaluated in three areas using the ZONEBUDGET post-processing software (Harbaugh, 1990) (figs. 18 and 19). The locations of areas were based on an enclosed cone of depression in the Grand Prairie area of Arkansas (Schrader, 2008) for the alluvial aquifer and stressed areas of the middle Claiborne aquifer in southern Arkansas and northern Louisiana (hereafter referred to as the Sparta recovery area) and Memphis, Tennessee (hereafter referred to as the Memphis area).

For the alluvial aquifer, pumpage is the dominant stress on the groundwater system in the Grand Prairie (fig. 18), which is similar to other stressed areas in the alluvial aquifer. Similarities within the alluvial aquifer are also evident in an evaluation of water-level declines. Schrader (2008) evaluated long-term water-level changes in the alluvial aquifer in Arkansas for the period 1982 to 2006. The annual water-level decline in a well in the Grand Prairie was approximately $0.80 \mathrm{ft} / \mathrm{yr}$. The saturated thickness of the alluvial aquifer near this well was approximately $30 \mathrm{ft}$ in the spring of 2008. By comparison, three wells north of the Grand Prairie area had similar annual water-level declines of $0.62,1.02$, and $1.28 \mathrm{ft} / \mathrm{yr}$. The saturated thickness of the alluvial aquifer near these wells north of the Grand Prairie area ranged from approximately 38 to $81 \mathrm{ft}$ in the spring of 2008. The annual water-level decline for a well in an area southeast of the Grand Prairie area in Mississippi was $0.69 \mathrm{ft} / \mathrm{yr}$ with a saturated thickness of approximately $80 \mathrm{ft}$ in the spring of 2008. The Grand Prairie and Mississippi areas appear to be the most similar in terms of average pumping per square mile and annual water-level decline, though the saturated thickness in Mississippi is more than twice that of the Grand Prairie. Reasons for this may be that pumping in the Grand Prairie may have begun earlier in time and with greater intensity than in Mississippi. On average, the water-level decline for the three wells north of the Grand Prairie area is greater than the Grand Prairie or Mississippi areas. The water-level declines also correspond well with the greater average pumping north of the Grand Prairie area. If the water-level declines were to continue in a linear fashion, the estimated time required to lower the water level to the bottom of the alluvial aquifer ranges from 30 to 130 years. This simple calculation is useful to bracket the period of time for which water may be available, but it does not take into account many variables such as pumping rates, recharge, or the likely inability to continue to pump water from the bottom of the aquifer because of reduced pump or well efficiencies.

Pumpage from the middle Claiborne aquifer is one to two orders of magnitude less than pumpage from the alluvial system. The large difference in pumping is attributed to fewer wells, lower aquifer permeability, and lower storage than the alluvial aquifer. However, because the middle Claiborne aquifer is confined, the volumes of groundwater pumped produce much larger water-level declines. Average pumping in the Sparta recovery area is substantially less than that from the Memphis area. Yet, the pumping in the Sparta recovery area has resulted in far greater water-level declines (over $360 \mathrm{ft}$ ) (Freiwald and Johnson, 2007) than the declines in the Memphis area (over $60 \mathrm{ft}$ ). The differences in water-level decline between the Sparta recovery and Memphis areas are attributed primarily to the much less permeable properties of the middle Claiborne aquifer in the Sparta recovery area (Clark and Hart, 2009).

Temporal variability throughout the system is driven primarily by increases and decreases in pumping from the alluvial aquifer related to irrigation demands and by changes in industrial and municipal pumpage from the middle Claiborne aquifer. Pumping amounts from the alluvial aquifer in the Grand Prairie area fluctuated with a slight trend in decreased pumping through the last 20 years of the simulation (late 1980s to 2006) (fig. 18). There is anecdotal evidence that the water levels in some areas of the alluvial aquifer in the Grand Prairie area have declined to the point where pumping is not feasible in recent years (relative to 2010). Simulated pumping in the MERAS model can be restricted when the water level falls below a set criterion in an attempt to simulate deterrence in pumping during low water-level conditions. These conditions result in a decrease in pumping from the alluvial aquifer in the Grand Prairie (fig. 18). Pumping from the middle Claiborne aquifer in the Memphis area increased rapidly until the 1970s and has since remained relatively constant.

Net interflow between adjacent units (excludes inflow from storage, recharge, and streams) also changes through time. In the Grand Prairie area, under predevelopment conditions, the small amount of water that entered from interflow from adjacent units was upward from the underlying Vicksburg-Jackson confining unit (fig. 19). This is consistent with the schematic in figure 6 that demonstrates groundwater discharging primarily upward to the alluvial aquifer. Near the end of the simulation, net interflow to the alluvial aquifer changes from upward flow from the Vicksburg-Jackson confining unit to primarily horizontal flow within the alluvial aquifer in the Grand Prairie (fig. 20). Net interflow to the middle Claiborne aquifer in the Grand Prairie area was primarily down from the alluvial aquifer under predevelopment conditions (fig. 19), which would occur near the western boundary of the Grand Prairie area, and secondarily from upward flow from the lower 


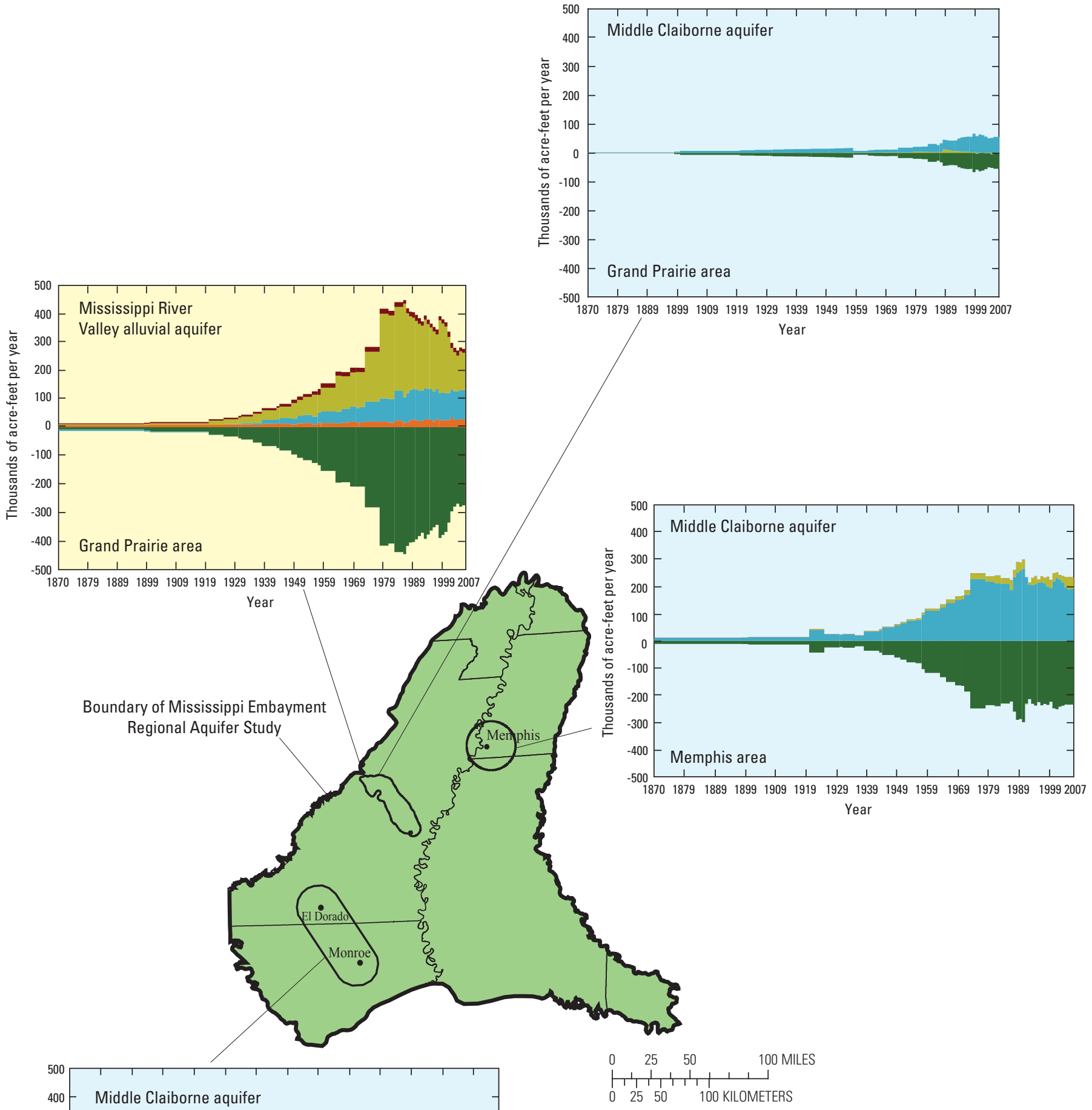

\section{EXPLANATION}

Net flow from adjacent aquifers and confining units

- Net pumpage from wells

Net withdrawal from or addition to storage

Net areal recharge

Net stream leakage

Figure 18. Groundwater-flow budgets of local areas. 


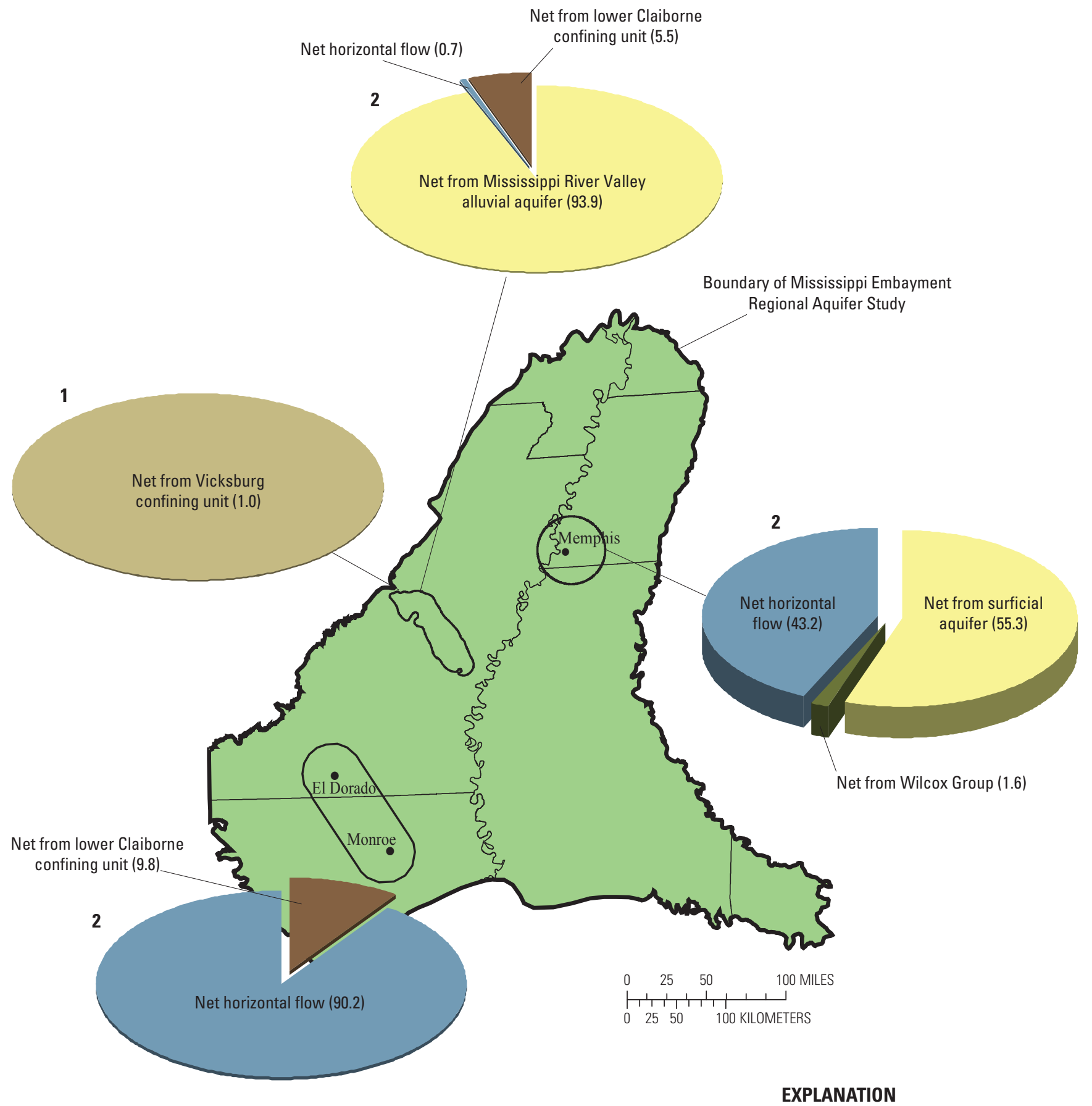

Interflow sources-Values in parenthesis represent the percent of the total inflow from adjacent units. The height of the pie charts are relative to the 2006 middle Claiborne inflow amount from adjacent zones or confining units. Percentages in pie charts may not total 100 percent because of rounding

1 To the Mississippi River Valley alluvial aquifer

2 To the middle Claiborne aquifer

Figure 19. Predevelopment groundwater-flow interactions with adjacent hydrogeologic units within local areas. 


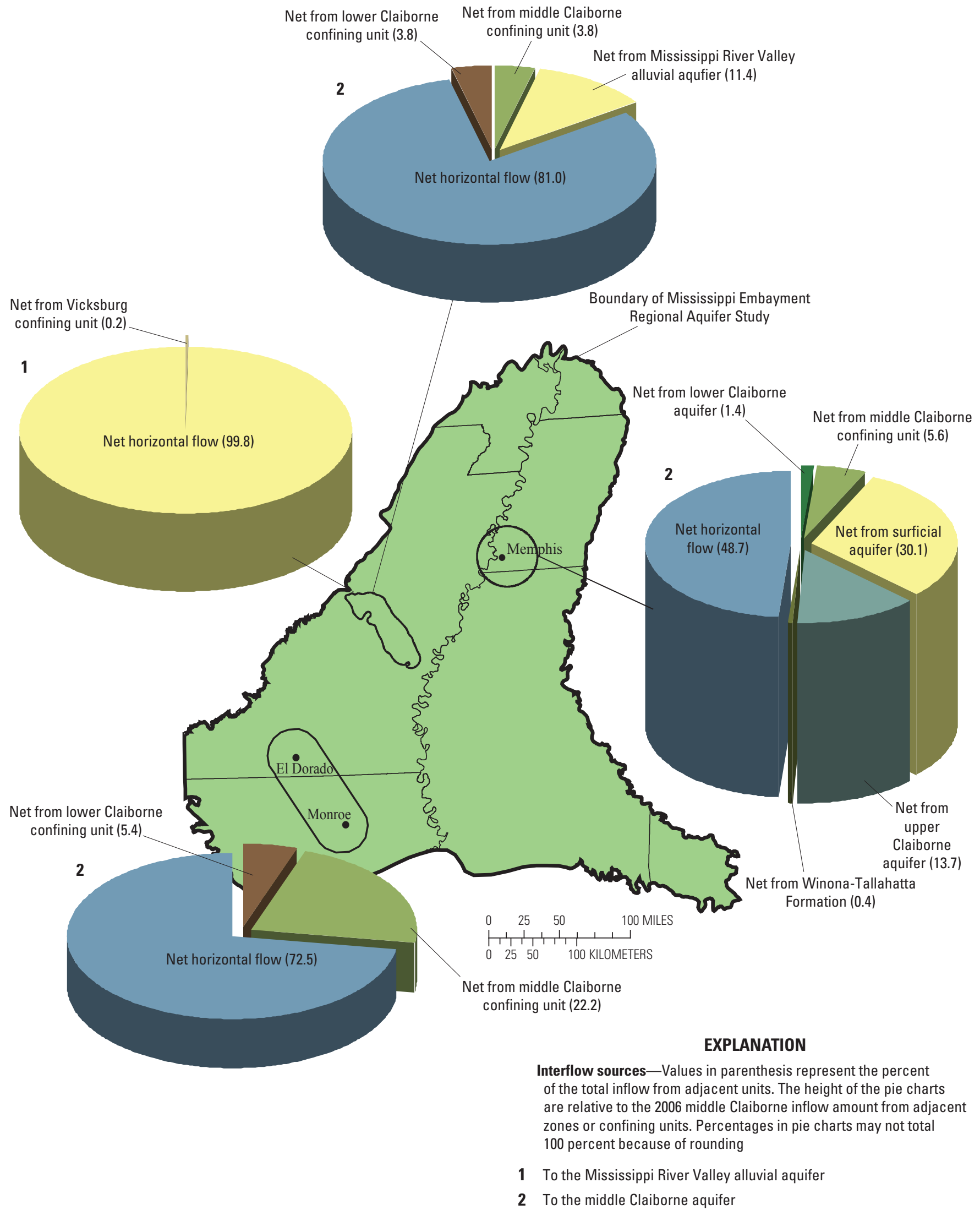

Figure 20. Postdevelopment groundwater-flow interactions with adjacent hydrogeologic units within local areas. 
Claiborne confining unit. This is also consistent with the schematic in figure 6, which describes groundwater movement into the recharge areas on the west and east side of the MERAS model and upward into overlying units.

The groundwater-budget analyses for the Sparta recovery and Memphis areas does not include the alluvial aquifer because it is not as extensive or is not in contact with the middle Claiborne aquifer in these zones. The simulated predevelopment budget indicates that flow into the Sparta recovery area is primarily horizontal from other parts of the middle Claiborne aquifer (net horizontal flow, fig. 19). While the primary interflow component in postdevelopment continues to be horizontal flow, 22.2 percent of the total inflow is now downward flow from the middle Claiborne confining unit, induced by a downward gradient in water level created by pumping (fig. 20). The simulated predevelopment budget for the middle Claiborne aquifer in the Memphis area indicates two primary sources, the first from the surficial aquifer and the second from horizontal flow from other parts of the middle Claiborne aquifer (fig. 19). The primary interflow components in postdevelopment in the Memphis area continues to be horizontal flow and flow from the surficial aquifer, though additional sources include downward (net) flow from the upper Claiborne aquifer and the middle Claiborne confining unit, and horizontal flow from the lower Claiborne aquifer (net from lower Claiborne aquifer, fig. 20). The Memphis area inflow derived from downward vertical leakage across confining units and from the surficial aquifer unit ranges from 40 to 55 percent of pumping for the period from 1980 to 2007. A study by Brahana and Broshears (2001) indicated that "more than 50 percent of the water withdrawn from the Memphis aquifer in 1980 is derived from vertical leakage across confining units, and the leakage from the shallow aquifer...". The similarity of the percent of downward leakage simulated by the MERAS model, and the study by Brahana and Broshears indicates little change in groundwater flow into the middle Claiborne aquifer occurred over the last 27 years, which may indicate near steady-state conditions in the Memphis area.

\section{Climate Trends and Potential Future Effects on Groundwater Availability}

Climate trends affect various components of the global hydrologic cycle in the space, time, and frequency domains (Loáiciga and others, 1996; Sherif and Singh, 1999; Milly and others, 2005; Holman, 2006; Intergovernmental Panel on Climate Change, 2007). Components of the hydrologic cycle that may be affected include atmospheric water vapor content, precipitation and evapotranspiration patterns, snow cover and melting of ice and glaciers, soil temperature and moisture, and surface runoff and streamflow (Bates and others, 2008). Changes to these components of the global hydrologic cycle will in turn likely affect recharge, discharge, and groundwater storage of many aquifers worldwide (Gurdak and others, 2009).
The potential effects of climate trends on water resources are well recognized, although there has been relatively little research relating to groundwater (Holman, 2006). Estimating the potential effects of climate trends on groundwater availability is difficult because changes in climate may affect hydrogeologic processes and groundwater availability directly and indirectly (Dettinger and Earman, 2007). The Intergovernmental Panel on Climate Change (IPCC) stated that a lack of necessary data currently (2007) makes it very challenging to determine the magnitude and direction of groundwater change resulting solely from human-induced climate change (Intergovernmental Panel on Climate Change, 2007; Kundzewicz and others, 2007). Groundwater availability has been affected since the mid-1900s by a number of other anthropogenic factors, such as contamination, reduction in streamflow because of pumping, lowering of the water table, and loss of storage because of groundwater mining (primarily for irrigated agriculture) (appendix 1) (Kundzewicz and others, 2007).

Additionally, groundwater systems often respond more slowly and have a greater temporal lag to climate trends than surfacewater systems, further challenging a clear understanding of climate-trend effects on groundwater availability (Chen and others, 2004; Hanson and others, 2004, 2006; Gurdak and others, 2008; Kundzewicz and others, 2007; Gurdak, 2008). This study is the first to quantify the cumulative interactions of natural climate variability on interannual to multidecadal timescales and groundwater pumping on the availability of groundwater in the MERAS.

\section{Hydroclimate Data Processing and Analysis}

Frequency analysis of hydroclimate data enables improved understanding of subsurface hydrologic responses to climate trends. The hydroclimate data processing and analysis employed in this study generally followed methods described by Hanson and others (2004) and Gurdak and others (2007).

The hydroclimate data analysis included groundwaterlevel time series from 40 wells, precipitation time series from 34 meteorological stations, streamflow time series from 8 USGS streamflow-gaging stations (appendix 2), and groundwater pumping records compiled from a larger network of hydrologic time series in the study area (Clark and Hart, 2009). The wells and meteorological stations were selected on the basis of the location of groundwater-level wells as well as the length and completeness of record. The water-level and streamflow data were obtained from USGS National Water Information System (U.S. Geological Survey, 2009). Monthly precipitation time-series data were obtained from the National Oceanic and Atmospheric Administration (2009b).

The first data-processing step (fig. 21) was designed to remove the influence of zero values common to precipitation time series and to integrate any incomplete groundwater-level records. This step was performed by transforming all hydrologic time series (fig. 21A) into monthly cumulative departure 

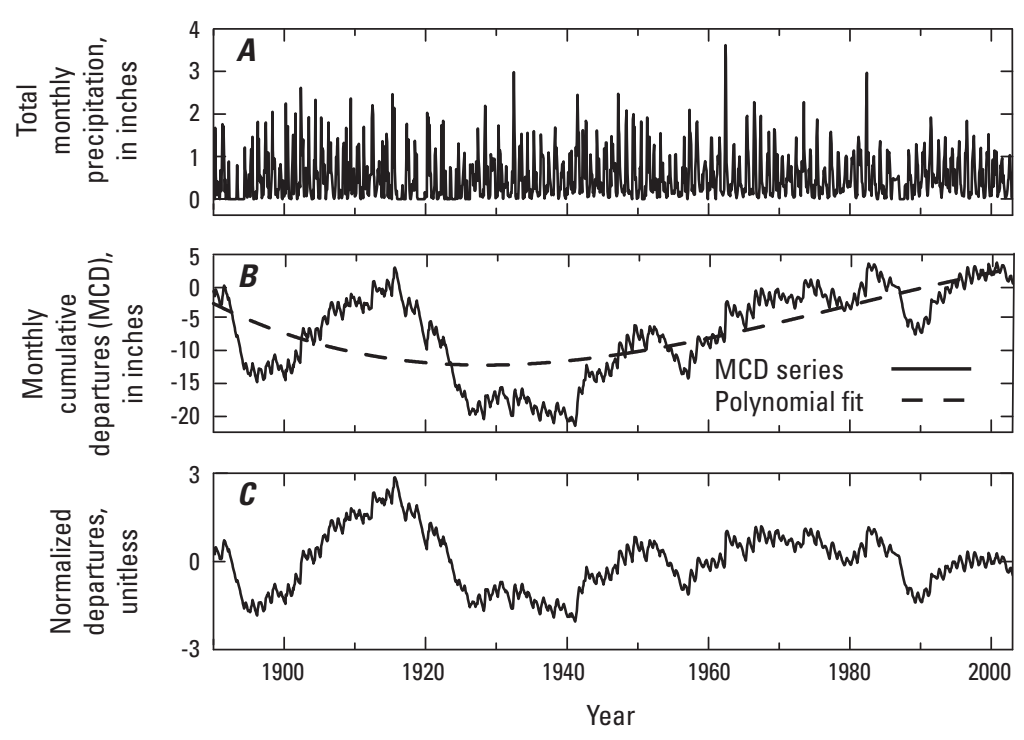

Figure 21. Demonstration of hydroclimate data-processing steps using $A$, total monthly precipitation time series, $B$, monthly cumulative departure (MCD), and $C$, normalized departure series.

series (fig. $21 B$ ) from the period of record using the monthly mean. Next, the residuals of the monthly cumulative departure series were obtained by subtracting a regression-fitted loworder (cubic) polynomial. The overall shape of the low-order polynomial represents interannual, multidecadal, or longer temporal trends (or responses) in the hydroclimate data to larger climatic cycles or periods of anthropogenic effects and tends to be dominated by the lowest frequency containing the most variance (Hanson and others, 2004). The residuals were finally normalized by the historic mean to facilitate statistical comparisons between various data types and are referred to as normalized departures (unitless) (fig. 21C). These data-processing steps effectively eliminated parts of the lowest-frequency cycles that would otherwise dominate the variance of the time-series analysis (Hanson and others, 2004). These steps were necessary to remove many of the long-term anthropogenic effects in the groundwater-level time series, such as implementation of improved irrigation technology, and annual anthropogenic effects, such as crop rotation and other irrigated-agricultural practices of the study area.

Using the computer software SSA-MTM Toolkit (Ghil and others, 2002; Dettinger and others, 1995) singular spectrum analysis (Vautard and others, 1992) was then applied during frequency analysis of the time-series residuals, using a modified approach developed by Hanson and others (2004) (appendix 2).

Extrapolations spanning 30 years of precipitation and streamflow inputs to the MERAS model were developed from the results of the singular spectrum analysis following a method described by Dettinger (2003). It should be stressed that the extrapolated precipitation and streamflow values generated for the MERAS model from this method are not climate predictions and likely will not prove to be precisely correct. As Dettinger (2003) describes, the method uses the singular spectrum analysis identified climate cycle reconstructed components and realistic randomness to generate extrapolations of precipitation that contain patterns of typical climate trends that may occur in the future. The method incorporated variability consistent with known climate cycles (such as AMO, PDO, and ENSO, appendix 1) and did not include climate cycles less than 2 years. The 30 -year extrapolations of precipitation were generated using the computer software kSpectra Toolkit 2.23 by fitting autoregressive models of various orders to the reconstructed components from the singular spectrum analysis of each precipitation time series and allowing those autoregressive models to step forward to forecast the reconstructed components for an additional 30 years. The reconstructed components for each precipitation time series are then converted back to precipitation values by stepping through the data-processing steps in reverse order. A similar method was used to extrapolate streamflow for streams crossing the MERAS model boundary. The extrapolation method incorporates less emphasis on the high-frequency noise inherent to the precipitation data than the lower-frequency trends, and thus produces extrapolated precipitation values that best approximate the lower frequency, interannual to multidecadal trends in precipitation of the study area. The 2-year average observed and extrapolated annual precipitation for the study area and selected meteorological stations are shown in figure 22. The hydroclimatic analysis used the low-order (cubic) polynomial trend to smooth out noise in the precipitation values, while also smoothing maximum and minimum values. This creates a much smoother precipitation pattern through time compared to actual precipitation values while forecasting 30-year extrapolations (fig. 22). The extrapolated 30-year precipitation values from each meteorological station were interpolated spatially across the model area for the time period 2008 to 2038 (appendix 3), which were subsequently used to generate continuous net recharge grids for the groundwater-flow model (as described in the next section). For more information on the extrapolation method used in this analysis see Dettinger (2003).

Net recharge in the MERAS model is specified as a fraction of precipitation (Clark and Hart, 2009). Therefore, grids of extrapolated precipitation (appendix 3 ) from the processed time series information were input into the MERAS model. The model then converted the precipitation values into specified net recharge (fig. 23). A drying period is evident from approximately 2008-24, followed by a wetter period from 2025 to the end of the simulation (fig. 22), which is the result of the forecasted future trends in the AMO and PDO phase variability. The forecasted shift from a drying to wetting trend in 2024 to 2025 is likely the result of a future shift from the negative $\mathrm{PDO}$ and positive AMO phase to a positive PDO and positive AMO phase. As discussed in the "Hydroclimate Data Processing and Analysis" section and depending on the future ENSO variability, the study area could experience 


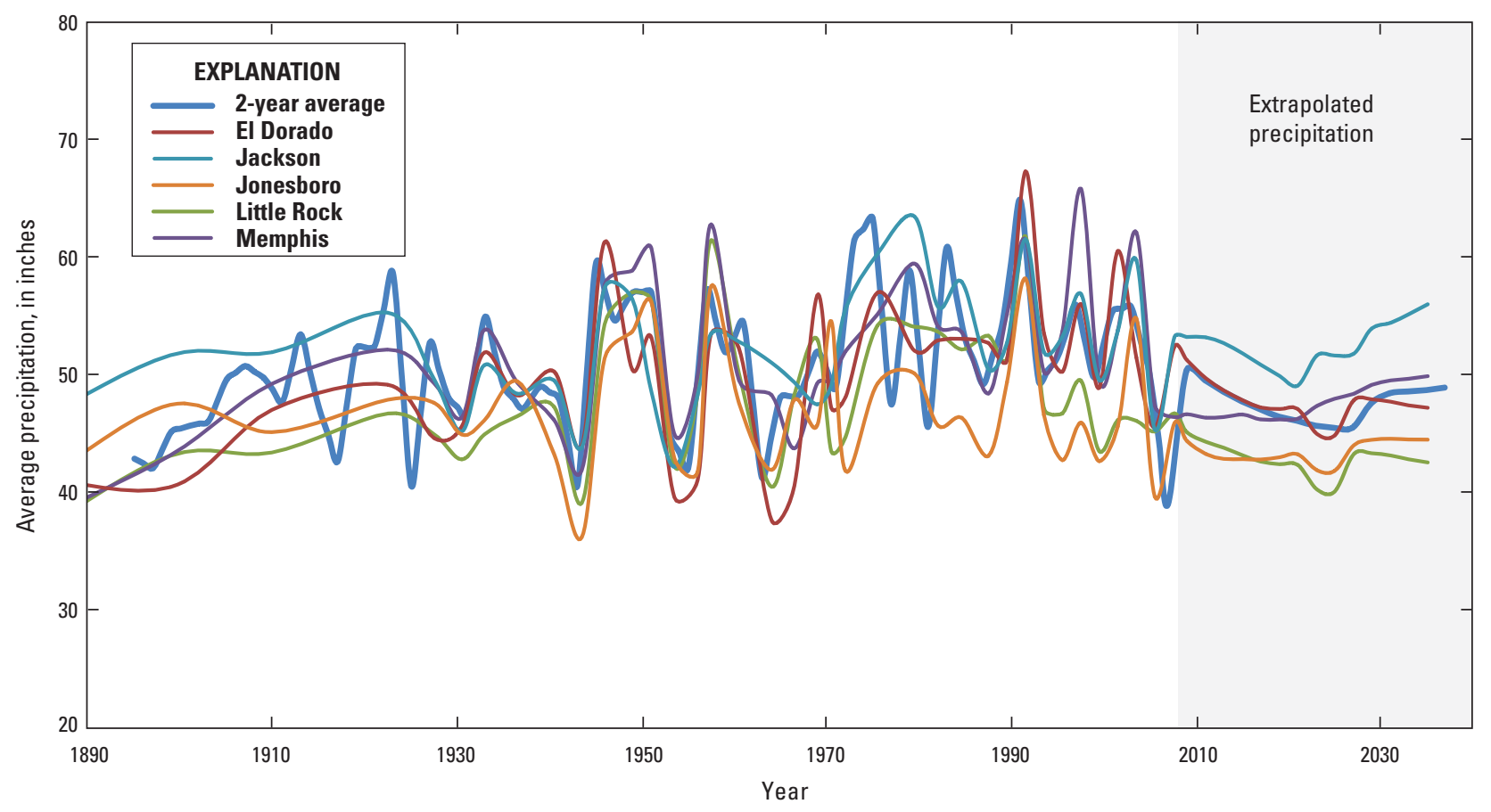

Figure 22. Average annual (2-year or more) precipitation values used in the MERAS model and selected meteorological stations including extrapolated precipitation data from 2008 to 2038.

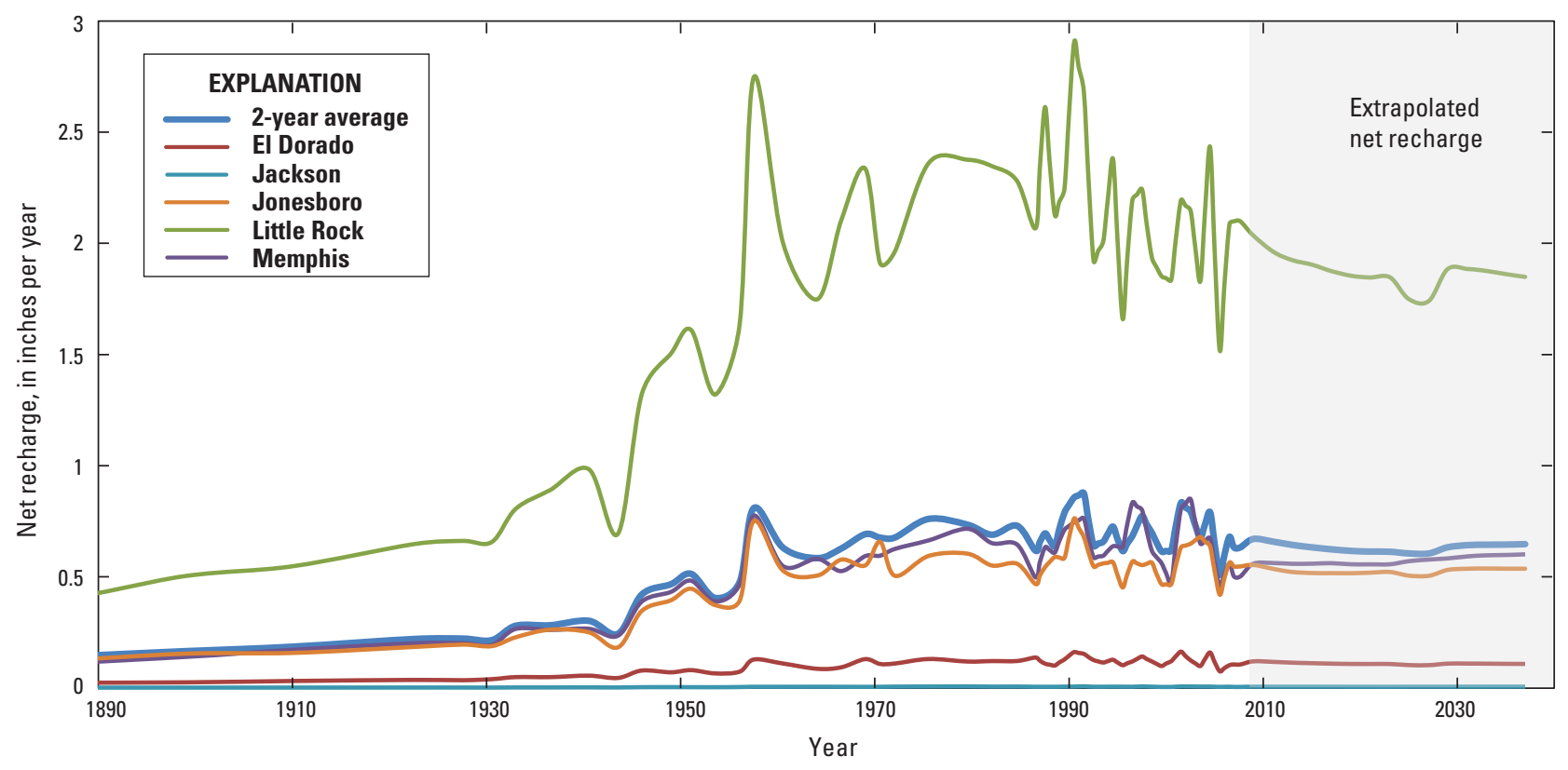

Figure 23. Specified net recharge at selected locations including extrapolated net recharge from 2008 to 2038. 
precipitation conditions between the forecasted 2008-24 period similar to those from the drought of the 1950s based on PDO and AMO variability. Although the forecasted shift from a drying to wetting trend in 2024 to 2025 may bring additional precipitation to the study area, the general trend is expected to be less than average precipitation because of the historical drought frequency during the positive PDO and positive AMO phase. In general, historical precipitation in the study area is greatest in the south and southeast and least in the north and northwest. Extrapolated grids of precipitation (appendix 3) follow a similar trend spatially, as lower precipitation areas are shown to continually have less precipitation, and higher precipitation areas are shown to continually have more precipitation. The spatial patterns of extrapolated precipitation during the drying phase (2008-24) are very similar to the spatial patterns of drought frequency during the negative PDO and positive AMO (McCabe and others, 2004) and discussed in "Hydroclimate Data Processing and Analysis," with relatively drier conditions in the west and northwest of the study area (appendix 3). The extrapolated precipitation during the drying phase (2008-24) represents a (-) 5 to 25 percent deviation from the observed annual precipitation at each meteorological station (appendix 3). Following the peak drying conditions between 2024 and 2028 in the southwestern part of the study area (appendix 3), the relative wetting trend begins in the southern part of the study area and propagates northward between 2028 and 2038 (appendix 3), which is very similar to the spatial patterns during the positive PDO and positive AMO as reported by McCabe and others (2004). Although some areas in the southern parts of the study area are shown to have as much as a 20-percent increase in average annual precipitation based on the observed annual precipitation, these areas are isolated and the majority of the study area is shown to have less than 5 to -25 percent deviation from the observed annual precipitation (appendix 3 ). The modest wetting trend between 2028 and 2038 is consistent with the drier than average conditions during the positive PDO and positive AMO (McCabe and others, 2004).

Global Climate Models (GCMs) do not accurately predict local climate trends, but in general, most GCMs predict an overall increase in temperature, globally, with the greatest predicted change in temperature to occur in the polar regions, specifically the Arctic region (Intergovernmental Panel on Climate Change, 2007). Also, the greatest predicted increases in precipitation are in the high-latitude regions, and the greatest decreases in precipitation are in most subtropical land regions (Intergovernmental Panel on Climate Change, 2007). Based on the IPCC GCM predictions, temperatures in the Mississippi embayment will increase slightly $\left(1-1.5^{\circ} \mathrm{C}\right)$, and precipitation will decrease slightly (approximately 5 percent) over the next 20 years (through 2029) contrasted with the high-latitude regions having up to a $3^{\circ} \mathrm{C}$ increase in temperature and 20 percent increase in precipitation (Intergovernmental
Panel on Climate Change, 2007). The GCM prediction of slight decreases in precipitation in the Mississippi embayment corresponds well with the precipitation inputs used in the climate scenario simulations in this professional paper. Each method appears to indicate that while climate trends likely will affect precipitation and temperature in the Mississippi embayment, the trends likely will be small compared to that in polar or subtropical land regions.

\section{Climate Simulation Development}

Two climate scenarios were simulated with the MERAS model by extending the simulation period by 30 years to 2038 . Sixteen stress periods were used to represent the projected 30 -year period. The first stress period is 275 days in length and extends the MERAS model to the end of 2007. Each stress period following 2007 is 2 years in length.

The first climate scenario (dry scenario) simulated with the MERAS model used changes in pumping from existing pumping centers and extrapolated net recharge changes (fig. 23). The change in precipitation from each location listed in figure 22 was compared to the change in total site-specific irrigation pumping from the Arkansas Natural Resources Commission Water Use Database System from 1995 to 2005 (U.S. Geological Survey, 2010c). The change in precipitation at Memphis, Tennessee, was more highly correlated to change in pumping with a square of the correlation coefficient $\left(\mathrm{R}^{2}\right)$ of 0.77 (fig. 24) than other locations. Based on this linear relation, the equation of the best fit line was used to solve for the fractional change in pumping from 2005 that would result from an extrapolated change in precipitation. The extrapolated precipitation at Memphis, Tennessee, resulted in a slight positive change in precipitation from 2005. The linear relation to pumping then dictates a negative change in irrigation pumping compared to 2005; a reduction of up to approximately 13 percent. Because 2005 is one of the driest years on record in the study area and pumping remains relatively high throughout the extrapolated part of the simulation, scenario 1 is considered to span a primarily dry period.

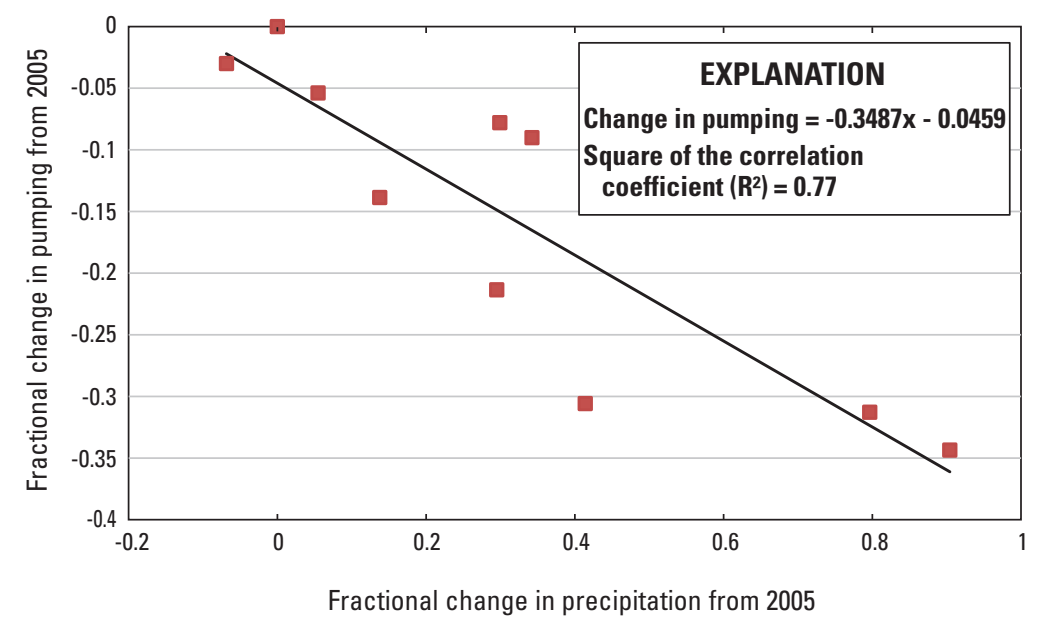

Figure 24. Relation between fractional change in pumping from 2005 and fractional change in precipitation at Memphis, Tennessee, from 2005. 
The second climate scenario (wet scenario) was constructed to provide a contrast to the dry period simulated with the first scenario by incorporating precipitation from one of the wettest periods (1991) occurring within the study area. Precipitation from 1991 was used as the input for the calculation of net recharge while maintaining the pumping used in the dry scenario so that a direct comparison of the effect of changes in precipitation could be made. Extrapolated streamflow was used in the dry and wet scenarios.

\section{Climate Trend Scenarios and Simulated Water Levels}

Water level continued to decline in both of the climate scenarios from 2007 simulated levels. The area containing more than $100 \mathrm{ft}$ of water-level decline in the alluvial aquifer increased from 2007 by 13.9 percent from 0.7 to 14.6 percent for the dry scenario (figs. 15 and 25). The area containing more than $100 \mathrm{ft}$ of decline in the middle Claiborne aquifer

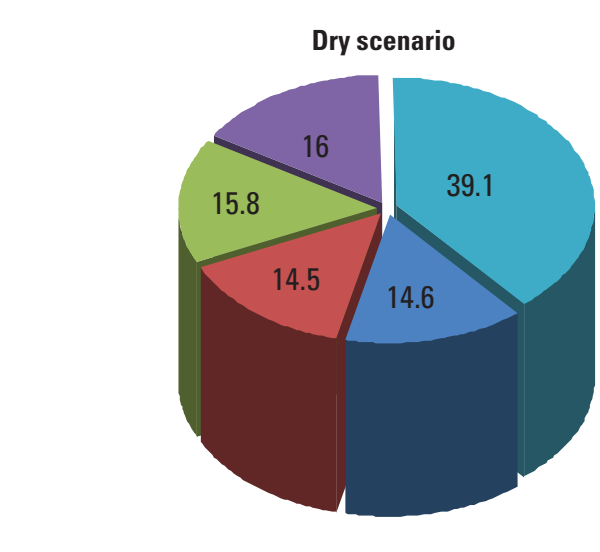

\title{
Mississippi River Valley alluvial aquifer
}

\author{
EXPLANATION \\ Percent of area of water-level decline \\ from predevelopment to 2038 , in feet \\ - Greater than 100 \\ - 76 to 100 \\ - 51 to 76 \\ - 25 to 50 \\ Less than 25
}

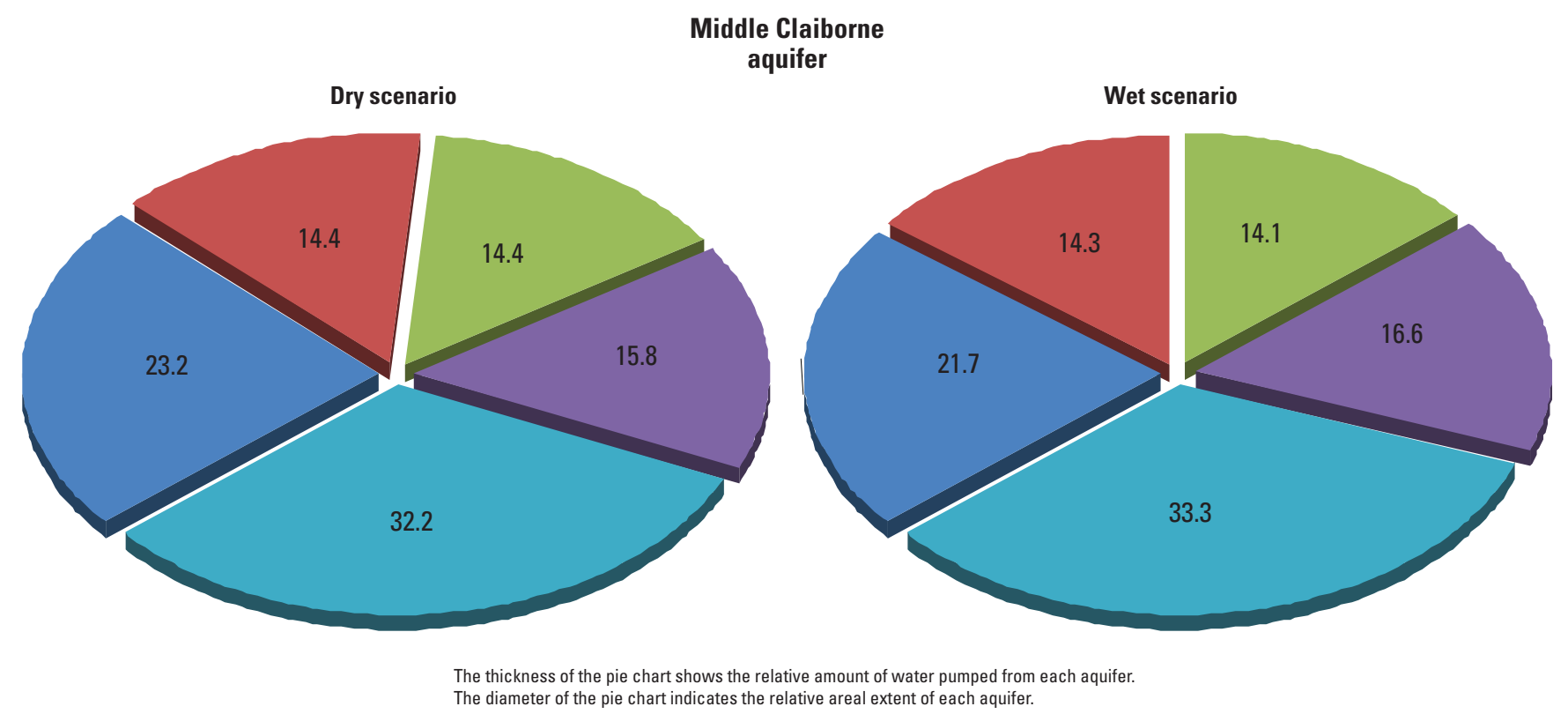

Figure 25. Percent area for water-level change groups from predevelopment to 2038 in the Mississippi River Valley alluvial aquifer and the middle Claiborne aquifer (dry and wet scenarios). 
increased from 2007 by 9.9 percent from 13.3 to 23.2 percent for the dry scenario (figs. 15 and 25). Spatially, the changes from 2007 to 2038 are most evident in the alluvial aquifer throughout almost all of Arkansas and a part of west-central Mississippi where the land area with declines greater than $25 \mathrm{ft}$ almost doubled (figs. $14 A$ and 26A). The areas of greatest decline in the alluvial aquifer are in southeastern Missouri and an area just west of Crowleys Ridge. While water levels have declined in the area west of Crowleys Ridge in recent years, water levels in the area of southeastern Missouri have not. This simulated decline may be the result of the continual decrease in precipitation forecasted in the northern part of the study area. The greatest water-level declines in the middle Claiborne aquifer remained in the southern part of the study area, in southern Arkansas and northern Louisiana. However, the maximum water level changed only by about $10 \mathrm{ft}$, which may indicate the effectiveness of conservation practices and alternative water supplies in these areas. More noticeable changes in the middle Claiborne aquifer occur throughout the remainder of Arkansas and into the southwestern corner of Tennessee (figs. 14B and 26B). Water-level changes in this part of the middle Claiborne aquifer tend to affect large areas commensurate with the confined condition of the aquifer and are in parts of the aquifer that likely are more affected by pumping in the alluvial aquifer (fig. 26B).

There is little difference between the dry and wet scenarios in terms of percent water-level change. Both scenarios resulted in 14.6 to 13.9 percent of the area containing greater than $100 \mathrm{ft}$ of decline, 14.5 to 13.8 percent containing between 75 and $100 \mathrm{ft}$ of decline, and 15.8 to 15.7 percent containing 51 to $75 \mathrm{ft}$ of decline in the alluvial aquifer (fig. 25). The middle Claiborne aquifer water-level changes were also similar between the two scenarios. These scenarios indicate that even with a 25-percent increase in precipitation from that of the dry scenario, there is little difference in the resultant water levels. This is in large part because of the magnitude of differences between changes in net recharge and changes in pumping. When compared to the volume of water pumped out of the system, the effect of this change in net recharge is negligible.

Whereas little difference exists between the dry and wet scenarios in terms of water-level change, this analysis is useful because it provides an example of the MERAS model as a tool to examine the sensitivity of the groundwater system to gradual long-term trends in precipitation. Analysis such as this using the MERAS model may be utilized to examine a host of scenarios and the resultant system response beyond those simulated by the scenarios presented here.

\section{Evaluation of Regional Groundwater-Level Monitoring Network}

Groundwater-level monitoring networks provide waterresource managers the ability to examine the current status and long-term trends in the hydrologic system. The location of wells in these monitoring networks and the timing of observed water-level measurements in these wells are critical to the management of the resource in a way that best suits anthropogenic and environmental needs. The MERAS model is one tool that can be used to evaluate the effectiveness of monitoring networks within the Mississippi embayment. The following evaluation documents a demonstration of one application using the MERAS model and the computer program OPR-PPR (Tonkin and others, 2007).

The groundwater-level monitoring network used to construct the 2007 middle Claiborne aquifer potentiometric surface (Schrader, 2007) was used to evaluate the importance of individual groundwater-level observations given current pumpage and recharge used in the dry climate scenario. The Observation-Prediction (OPR) statistic indicates the relative importance of an observation to a prediction (Tonkin and others, 2007). The MERAS model documented in Clark and Hart (2009) and the MERAS model simulation of the dry climate scenario provides a base model and a prediction model for evaluating the importance of observed water-level altitudes.

OPR-PPR was used in two modes, OPROMIT and OPRADD, to omit existing observations and add new potential observations, respectively. OPROMIT was used to calculate the importance of observations by measuring the percent change in prediction standard deviation caused by omitting the observations. OPRADD works in the same manner by adding new observations.

\section{Existing Monitoring Networks}

Multiple groundwater-level monitoring networks exist in the Mississippi embayment. In the middle Claiborne aquifer, a total of 748 water-level measurements were used to create an embayment-wide potentiometric-surface map (Schrader, 2007). Of these monitoring networks, many are used routinely to develop potentiometric-surface maps within individual States or pairs of States (Stanton, 1997; Brantly and others, 2002; Schrader, 2004; Schrader and Jones, 2007). A similar water-level network currently exists in some areas of the alluvial aquifer (Schrader, 2006, 2008). Several State and local agencies also collect water-level information.

\section{Network Analysis}

For the middle Claiborne aquifer, many of the water levels used to construct the potentiometric-surface representing 2007 conditions also were used as observations (for calibration purposes) in the MERAS model. In step one of this evaluation, all middle Claiborne aquifer water levels that also were used in the construction of the 2007 potentiometric-surface map were omitted using the OPROMIT mode of OPR-PPR to calculate their relative importance. In step two, any observed water levels at monitoring wells used in the 2007 potentiometric-surface map that had not been used in the MERAS model calibration were then added as new observations using the OPRADD mode of OPR-PPR to 


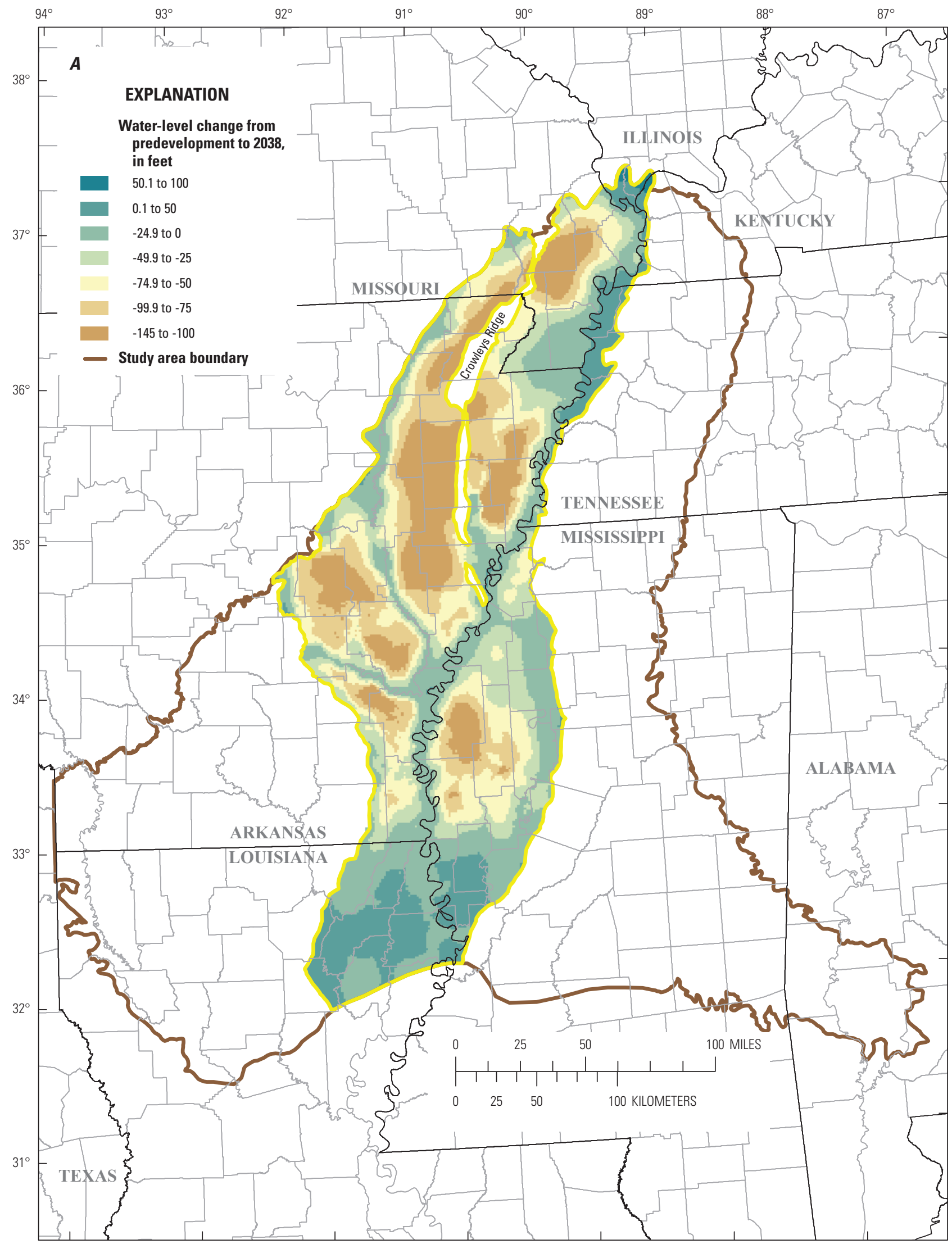

Base from U.S. Geological Survey digital data, 1:100,000

Figure 26. Water-level change of the dry scenario from predevelopment to 2038 in the $A$, Mississippi River Valley alluvial aquifer and $B$, the middle Claiborne aquifer. 


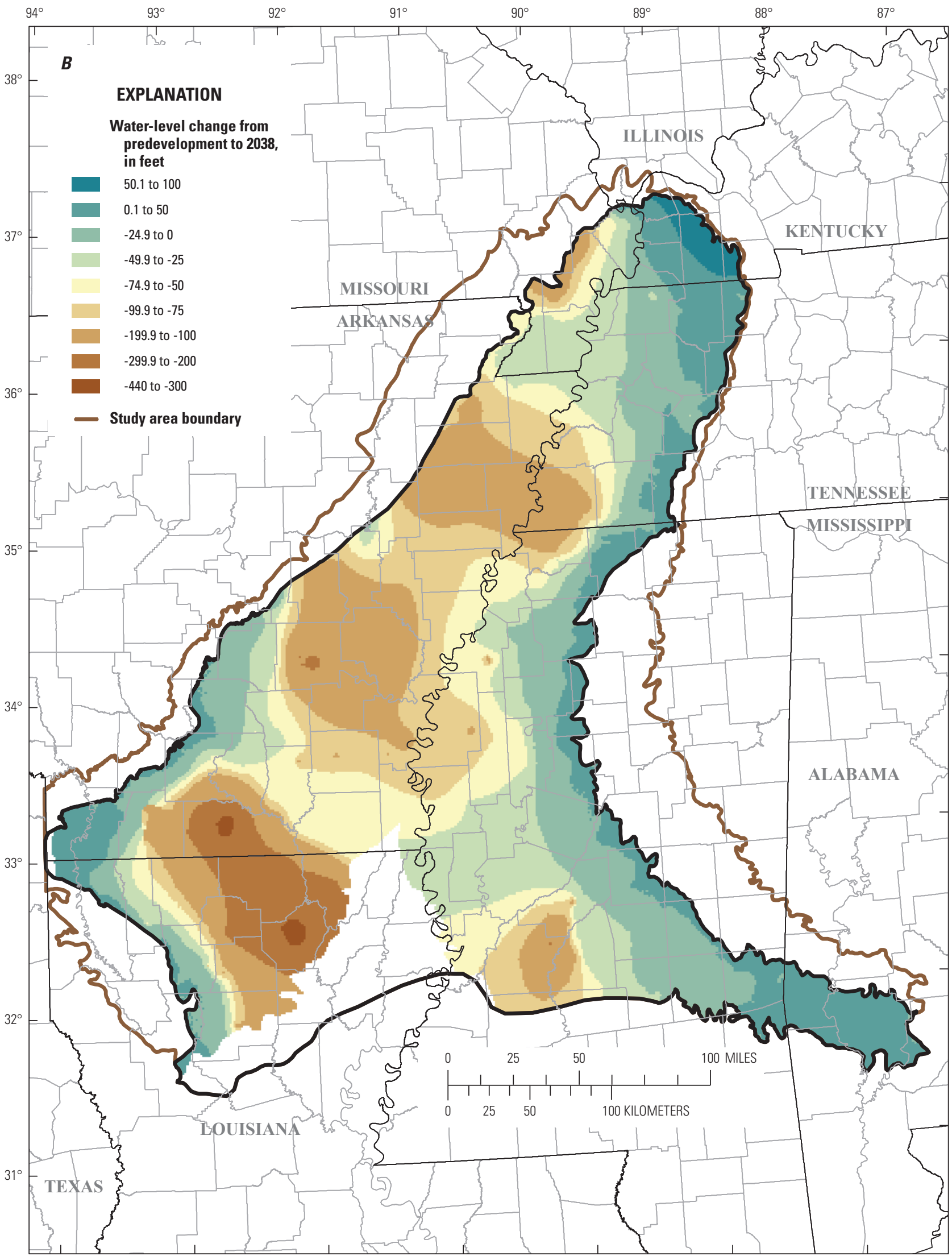

Base from U.S. Geological Survey digital data, 1:100,000

Figure 26. Water-level change of the dry scenario from predevelopment to 2038 in the $A$, Mississippi River Valley alluvial aquifer and $B$, the middle Claiborne aquifer.-Continued 
evaluate the relative importance of observed water levels at these wells. It is important to note there are many more waterlevel observations in the MERAS model, both spatially and temporally, than the sum of those omitted and added as part of this evaluation.

To calculate the importance of each 2007 middle Claiborne aquifer observation to a prediction, OPR-PPR predictions were specified as water-level altitudes near the end of the dry scenario simulation. These water-level altitudes were located near the center of cones of depression described by Schrader (2007) and were based on the simulated 2038 water level of the middle Claiborne aquifer. Using these predictions (prediction locations) and the observations of the 2007 middle Claiborne aquifer monitoring network, a map was created representing the percent decrease of uncertainty (relative importance) related to each observation (fig. 27). Many of the observations that have a high importance are in close proximity to stressed areas of the aquifer. Some, however, rank higher than might be expected based on location, such as the high relative importance of observations in Mississippi in the southeastern part of the study area. The reasons for the high relative importance of these observations in Mississippi are two-fold:

(1) the observations and the nearby predictions share high sensitivity to common parameters, and (2) the observations are in an area of sparse observations making the sensitivities higher than observations in areas where multiple observations exist. The results also indicate relative low importance of many of the observations in southern Arkansas and northern Louisiana. However, the ranking of these observations are based solely on the predictions used in this analysis.

It is important to note that this analysis reflects the importance of observations under the current stress conditions in this particular model. The addition of new, high-volume pumping centers in a relatively unstressed area of the middle Claiborne aquifer may alter these results. This underscores the ability of the technique to evaluate a groundwater-monitoring network under a variety of situations.

\section{Groundwater-Flow Model Improvements}

Improvements made in the development of the MERAS model include a refined hydrogeologic framework, the ability to simulate routed streamflow, the ability to simulate flow through wells screened in multiple aquifers, and the incorporation of available site-specific water use. The MERAS model incorporates data from more than 2,600 geophysical logs used to interpret the thickness and extent of hydrogeologic units in the study area that encompasses $78,000 \mathrm{mi}^{2}$. Though gaps in data exist, the dataset of geophysical information is valuable and is a refinement of the understanding gained through the Gulf Coast Regional Aquifer System Analysis program. Geophysical logs in the dataset can also be helpful in interpreting the quality of groundwater. At the time of writing this report, studies are underway to expand the knowledge of aquifers with elevated salinity values that, with treatment, could become sources of water acceptable for human use. The MERAS model is one of the first regional models in the Mississippi embayment to incorporate the SFR Package of MODFLOW. The use of SFR in the model removes the constraints of specifying a fixed hydraulic head within the streams allowing the model to simulate the interaction of the stream with the aquifer and route the water downstream to the next model cell. By using the MNW Package of MODFLOW, the model can simulate flow through the well bore from multiple layers. This may be useful in areas such as the Grand Prairie, where anecdotal evidence exists for multiscreened wells, but the effect of these wells on the system is not known.

Additionally, the MERAS model simulates all aquifers and confining units in the Mississippi embayment, including the alluvial aquifer, in a single groundwater-flow model. Previous models were forced to constrain the study area to a select set of aquifers or geographic region because of limitations of data or computer computational time. The holistic simulation by the MERAS model allows analysis of the larger regional and aquifer scale system to better understand how all the parts interact.

The demonstration of OPR-PPR used in this report provides an example to evaluate groundwater-level monitoring networks in this holistic view. The utilization of OPR-PPR in a multi-aquifer system such as simulated by the MERAS model not only provides information on the importance of observations relative to stresses in other aquifers in the system, but also may help optimize the placement and timing of waterlevel observations under tight fiscal budgets.

\section{Challenges for Future Groundwater Availability Determinations- Limitations and Lessons Learned}

Groundwater models are a simplification of the real world. As such, improvements are always possible in many areas. As with most models, the parameter values and input data used in the MERAS model are considered nonunique, thus a different combination of values could produce similar results. Caution is needed when making groundwater management decisions based on the steady-state and transient simulations described in this report in lieu of the stated assumptions and limitations. For example, actual water-level declines in wells will differ from computed values, and declines in or near individual high-capacity pumping wells generally will be greater. The MERAS model could be improved with increased knowledge of recharge rates, water use, evapotranspiration, and stream leakage. Each of these limiting data sets is described in detail as follows.

Information on the amount of recharge entering the groundwater system and the amount of groundwater pumped from the various aquifers (water use) is crucial to the MERAS 


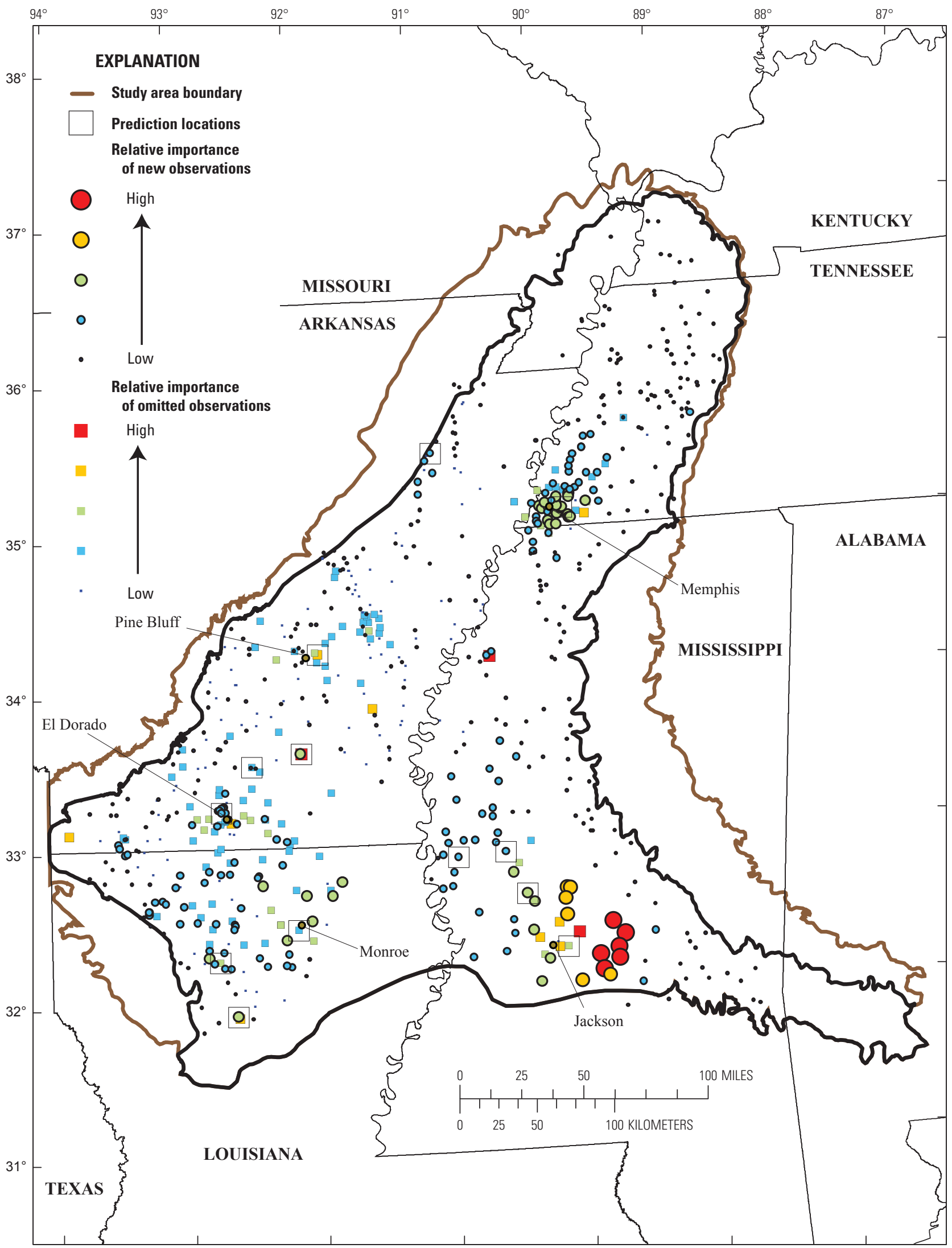

Base from U.S. Geological Survey digital data, 1:100,000

Figure 27. Results of OPR-PPR showing the relative importance of spring 2007 water-level observations in the middle Claiborne aquifer. 
model. While some site-specific information on water use exists in some areas, particularly irrigation water use in Arkansas, the period of record for this information is within the last 10 to 15 years, which is a relatively small amount of time compared to the simulation period of 137 years. Over much of the study area and simulation period, each of these datasets related to recharge and water use currently (2007) has little or no information based on actual measured values. Net recharge in the MERAS model is calibrated based on water level and streamflow observations. The range of net recharge values in the MERAS model are within values used by past models constructed in the study area and based on streamflow separation methods. However, field values to validate these ranges are sparse or difficult to compare.

ET is not currently explicitly simulated in the MERAS model, though it is possible to incorporate ET as a package within MODFLOW-2005. By the explicit simulation of ET, the modifications made to the net recharge early in the simulation (predevelopment to the 1960s) might not be necessary. The explicit simulation of ET would also help in removing groundwater at other periods during the simulation if water levels rise to the point that ET effects would be active.

Water use as simulated in the MERAS model was derived from a combination of trend analysis, water-use estimates, and reported data. Estimated pumpage amounts and distribution are evident in the middle Claiborne aquifer in the Grand Prairie area where there is an increase in pumping through 1958, then a sharp reduction around 1960, followed by a continued increase to 2006 (fig. 18). The sharp reduction around 1960 is an artifact of a change in pumping distribution based on a water-use trend analysis using State level data to a distribution based on county level data (Clark and Hart, 2009). At the regional scale, these water-use and pumping distribution discrepancies tend to be less noticeable (fig. 12). One of the primary reasons for this study is to evaluate and understand the availability of water for human (including agricultural) and environmental requirements. To understand the availability of water for human requirements, a reasonable estimate of past, current, and future amounts of water use need to be determined. For many areas of the Mississippi embayment, records of the amount of water for municipal and industrial use are maintained in paper or electronic format on a monthly basis. Well locations and water-use values in the MERAS model represent one possible configuration, but the real configuration (actual well locations and amounts of pumpage over the last 137 years) is to a large extent unknown. Reporting and validating of wateruse amounts are crucial to the development of groundwater models that can accurately represent groundwater flow in regional and local settings. It is notable that the total amount of estimated groundwater use in 2005 of almost 12 million acre-ft/yr is 1.27 million acre-ft/yr more than the total simulated by the MERAS model (10.73 million acre-ft/yr in 2005 , or 10.65 million acre-ft/yr in 2006). This difference is likely the result of drawdown constraints placed on each well in the MERAS model noted in Clark and Hart (2009). These constraints allowed the desired pumping from a well to be decreased or turned off based on the water level in the surrounding aquifer. Uncertainty in the simulation of water level in the MERAS model may consequently have caused the decreased pumping simulated by the model. This difference could also be the result of inaccuracies in the estimate of groundwater pumping.

It has long been assumed that there is a large amount of interaction between the many miles of streams and canals with the aquifers in the study area. To simulate stream leakage in the MERAS model, basic factors such as the thickness and hydraulic conductivity of the streambed are required. Very few studies exist to quantify these streambed factors. Studies are needed to examine the importance of the stream interaction on an annual time scale because these studies have indicated that over long time periods (annual or longer) there is a net zero exchange of water between streams and the aquifer system.

There are also limitations associated with the hydroclimate data processing and analysis. The analysis uses a low-order polynomial trend to smooth out noise in the precipitation values, which results in the inability to forecast episodic (high variability) precipitation events. It is possible that episodic events induce larger, though perhaps shortterm (less than 1-year) changes in the groundwater system. However, it is these short-term changes that may have a larger effect on the agriculturally based economy of the Mississippi embayment.

\section{Scaling Regional to Local Issues}

The MERAS model was designed to evaluate groundwater flow on a regional scale. However, the value of having regional perspective provides context such as well-established boundary conditions that enables smaller scale analysis. In some areas, local information may be available to better represent groundwater flow on a local scale. In these instances, the MERAS model may provide a useful structure to build the local-scale model and the groundwater-flow boundary conditions where hydrogeologic boundaries do not naturally exist. An example of this might include the use of data from geophysical logs that are pertinent to the local area of interest. These data may be added to the existing regional data to create interpretations of local hydrogeologic units for use in the local model. One suggestion to incorporate these new data is the use of Local Grid Refinement (Mehl and Hill, 2007), which allows the interaction of a local-scale model grid with the regional-scale model grid. A local-scale model may use smaller grid cells with different hydraulic properties and more refined vertical layers than the regional model to better simulate effects on flow and water levels from local stresses, such as pumping. 


\section{Acknowledgments}

The Mississippi Embayment Regional Aquifer Study (MERAS) was conducted with support from the U.S. Geological Survey Groundwater Resources Program. The authors wish to thank many talented individuals that have contributed to this Professional Paper. Suggestions by Arlen Harbaugh, Tom Reilly, Kevin Dennehy, and Randall T. Hanson were invaluable throughout the modeling and report process, and Alyssa Dausman and Geoff Delin, who served as technical reviewers. Extensive assistance by Claire Teideman and Matt Tonkin were crucial for the analysis of OPR-PPR. The experience and knowledge in regional-scale models provided by Claudia Faunt was a huge benefit to this report, as well as the preparation of previous MERAS reports.

\section{References}

Ackerman, D.J., 1989, Hydrology of the Mississippi River Valley alluvial aquifer, south-central United States-A preliminary assessment of the regional flow system: U.S. Geological Survey Water-Resources Investigations Report $88-4028,80 \mathrm{p}$.

Ackerman, D.J., 1996, Hydrology of the Mississippi River Valley alluvial aquifer, south-central United States: U.S. Geological Survey Professional Paper, 1416-D, 56 p.

Allen, M.R., and Smith, L.A., 1996, Monte Carlo SSA: Detecting irregular oscillations in the presence of colored noise: Journal of Climate, v. 9, no. 12, p. 3,373-3,404.

Alley, W.M., 2007, Another water budget myth: The significance of recoverable ground water in storage: Ground Water, v. 45 , no. 3, p. 251.

Arthur, J.K., and Taylor, R.E., 1998, Ground-water flow analysis of the Mississippi embayment aquifer system, southcentral United States: U.S. Geological Survey Professional Paper, 1416-I, 148 p.

Arthur, J.K., 2001, Hydrogeology, model description, and flow analysis of the Mississippi River alluvial aquifer in northwestern Mississippi: U.S. Geological Survey WaterResources Investigations Report 2001-4035, 47 p.

Bates, B.C., Kundzewicz, Z.W., Wu, S., and Palutikof, JP., 2008, Climate change and water: Technical paper VI of the Intergovernmental Panel on Climate Change (IPCC), IPCC Secretariat, Geneva, $210 \mathrm{p}$.

Bennett, G.D., 1979, Regional ground-water systems analysis: U.S. Army Corps of Engineers Water Spectrum, v. 11, no. 4, p. 36-42.
Brahana, J.V., and Broshears, R.E., 2001, Hydrogeology and ground-water flow in the Memphis and Fort Pillow aquifers in the Memphis area, Tennessee: U.S. Geological Survey Water-Resources Investigations Report 89-4131, 56 p.

Brahana, J.V., and Mesko, T.O., 1988, Hydrogeology and preliminary assessment of regional flow in the Upper Cretaceous and adjacent aquifers in the northern Mississippi embayment: U.S. Geological Survey Water-Resources Investigations Report, 87-4000, 65 p.

Brantly, J.A., Seanor, R.C., and McCoy, K.L., 2002, Louisiana ground-water map no. 13: Hydrogeology and potentiometric surface of the Sparta aquifer in northern Louisiana, October 1996: U.S. Geological Survey Water-Resources Investigations Report 2002-4053, 2 sheets.

Charlier, T., 2010, Supreme Court shuts off Mississippi's water lawsuit against Memphis: accessed April 24, 2011, at $h t t p: / / w w w . c o m m e r c i a l a p p e a l . c o m / n e w s / 2010 / j a n / 25 /$ supreme-court-declines-weigh-mississippis-water-la/.

Chen, Z., Grasby, S.E., and Osadetz, K.G., 2004, Relation between climate variability and groundwater levels in the upper carbonate aquifer, southern Manitoba, Canada: Journal of Hydrology, v. 290, no. 1-2, p. 43-62.

Clark, B.R., and Hart, R.M., 2009, The Mississippi embayment regional aquifer study (MERAS): Documentation of a groundwater-flow model constructed to assess water availability in the Mississippi embayment: U.S. Geological Survey Scientific Investigations Report 2009-5172, $61 \mathrm{p}$.

Criner, J.H., and Parks, W.S., 1976, Historic water-level changes and pumpage from the principal aquifers of the Memphis area, Tennessee: 1886-1975: U.S. Geological Survey Water-Resources Investigations Report 76-67, 45 p.

Cushing, E.M., Boswell, E.H., Speer, P.R., and Hosman, R.L., 1970, Availability of water in the Mississippi embayment: U.S. Geological Survey Professional Paper 448-A, 11 p.

Dettinger, M.D., Ghil, M., Strong, C.M., Weibel, W., and Yiou, P., 1995, Software expedites singular-spectrum analysis of noisy time series: Eos, Transactions of the American Geophysical Union, 76, no. 2, p. 12, 14, 21.

Dettinger, M.D., 2003, Appendix 3: Documentation of methods used to project climate scenarios for the next 50 years for the Santa Clara-Calleguas Basin: in Hanson, T.R., Martin, Peter, and Koczot, K.M., 2003, Simulation of ground-water/surface-water flow in the Santa ClaraCalleguas ground-water basin, Ventura County, California: U.S. Geological Survey Water-Resources Investigations Report 02-4136, $214 \mathrm{p}$. 
Dettinger, M., and Earman, S., 2007, Western ground water and climate change-Pivotal to supply sustainability or vulnerable in its own right?: Ground Water, 4, no. 1, p. 4-5.

Dickinson, J.E., Hanson, R.T., Ferré, T.P.A., and Leake, S.A., 2004, Inferring time-varying recharge from inverse analysis of long-term water levels: Water Resources Research, v. 40, no. 7, W07403, doi:10.1029/2003WR002650.

Enfield, D.B., Mestas-Nuñez, A.M., and Trimble, P.J., 2001, The Atlantic multidecadal oscillation and its relation to rainfall and river flows in the continental U.S.: Geophysical Research Letters, v. 28, no. 10, p. 2,077-2,080.

Engler, Kyle, Thompson, D.G., and Kazmann, R.G., 1945, Ground water supplies for rice irrigation in the Grand Prairie Region, Arkansas: Fayetteville, Ark., University of Arkansas College of Agriculture Bulletin No. 457, 56 p.

Fenneman, N.M., and Johnson, D.W., 1946, Physical divisions of the United States (Map): Washington D.C., U.S. Geological Survey.

Fitzpatrick, D.J., Kilpatrick, J.M., and McWreath, H.,1990, Geohydrologic characteristics and simulated response to pumping stresses in the Sparta aquifer in east-central Arkansas: U.S. Geological Survey Water-Resources Investigations Report 88-4201, 50 p.

Freiwald, D.A., and Johnson, S.F., 2007, Monitoring of Sparta aquifer recovery in Southern Arkansas and Northern Louisiana, 2003-07: U.S. Geological Survey Fact Sheet 2007-3102, 4 p.

Freeze, R.A., and Cherry, J.A., 1979, Groundwater: Englewood Cliffs, New Jersey, Prentice-Hall, 604 p.

Fye, F.K., Stahle, D.W., Cook, E.R., and Cleaveland, M.K., 2006, NAO influence on sub-decadal moisture variability over central North America: Geophysical Research Letters, v. 33:L15707, doi:10.1029/2006GL026656.

Ghil, Michael, 2002, Natural climate variability, in MacCraken, M.C., and Perry, J.S., eds., Encyclopedia of global environmental change-Volume 1, The Earth systemPhysical and chemical dimensions of global environmental change: Chichester, John Wiley and Sons, p. 544-549.

Ghil, Michael, Allen, R.M., Dettinger, M.D., Ide, K., Kondrashov, D., Mann, M.E., Robertson, A., Saunders, A., Tian, Y., Varadi, F., and Yiou, P., 2002, Advanced spectral methods for climatic time series: Review of Geophysics, 40, no. 1, p. 3.1-3.41, 10.1029/2000RG000092.

Grubb, H.F., 1998, Summary of hydrology of the regional aquifer systems, Gulf Coastal Plain, south-central United States: U.S. Geological Survey Professional Paper 1416-A.
Gurdak, J.J., Hanson, R.T., McMahon, P.B., Bruce, B.W., McCray, J.E., Thyne, G.D., and Reedy, R.C., 2007, Climate variability controls on unsaturated water and chemical movement, High Plains aquifer, USA: Vadose Zone Journal, v. 6 , no. 3 , p. 533-547.

Gurdak, J.J., 2008, Ground-water vulnerability: Nonpointsource contamination, climate variability, and the High Plains aquifer: VDM Verlag Publishing, Saarbrucken, Germany, ISBN: 978-3-639-09427-5, 223 p.

Gurdak, J.J., Clark, B.R., Hanson, R.T., and Scheiderer, R.M., 2008, Ground-water availability responses to climate variability on interannual to multidecadal timescales, Mississippi embayment Regional Aquifer System, USA: Eos Transactions, American Geophysical Union Fall Meeting Supplement, Abstract H12D-07.

Gurdak, J.J., Hanson, R.T., and Green, T.R., 2009. Effects of climate variability and change on groundwater resources of the United States: U.S. Geological Survey Fact Sheet 2009-3074, 4 p. (also available at http://pubs.usgs.gov/ fs/2009/3074/.

Halford, K.J., and Hanson, R.T., 2002, User guide for the drawdown-limited, multi-node well (MNW) package for the U.S. Geological Survey's modular three-dimensional finite-difference ground-water flow model, versions MODFLOW-96 and MODFLOW-2000: U.S. Geological Survey Open-File Report 02-293, 33 p.

Hanson, R.T., Martin, Peter, and Koczot, K.M., 2003, Simulation of ground-water/surface-water flow in the Santa Clara-Calleguas ground-water basin, Ventura County, California: U.S. Geological Survey Water-Resources Investigations Report 02-4136, X p.

Hanson, R.T., Newhouse, M.W., and Dettinger, M.D., 2004, A methodology to assess relations between climatic variability and variations in hydrologic time series in the southwestern United States: Journal of Hydrology, v. 287, no. 1-4, p. 252-269.

Hanson, R.T., Dettinger, M.D., and Newhouse, M.W., 2006, Relations between climatic variability and hydrologic time series from four alluvial basins across the southwestern United States: Hydrogeology Journal, v. 14, no. 7, p. 1,1221,146 .

Harbaugh, A.W., 2005, MODFLOW-2005, the U.S. Geological Survey modular ground-water model-The groundwater flow process: U.S. Geological Survey Techniques and Methods, book 6, chap. A16, variously paged.

Harbaugh, A.W., 1990, A computer program for calculating subregional water budgets using results from the U.S. Geological Survey Modular three-dimensional finite-difference ground-water flow Model: U.S. Geological Survey OpenFile Report 90-392, 24 p. 
Hart, R.M., Clark, B.R., and Bolyard, S.E., 2008, Digital hydrogeologic surface and thickness for the hydrogeologic units of the Mississippi Embayment Regional Aquifer Study (MERAS): U.S. Geological Survey Scientific Investigations Report 2008-5098, 33 p., accessed December 4, 2008, at http://pubs.usgs.gov/sir/2008/5098.

Hart, R.M., and Clark, B.R., 2008, Geophysical well-log database for the Mississippi Embayment Regional Aquifer Study (MERAS): U.S. Geological Survey Scientific Investigations Report 2008-5192, 8 p., accessed December 4, 2008, at http://pubs.usgs.gov/sir/2008/5192.

Hays, P.D, Lovelace, J.K., and Reed, T.B., 1998, Simulated response to pumping stress in the Sparta aquifer of southeastern Arkansas and north-central Louisiana, 1998-2027: U.S. Geological Survey Water-Resources Investigations Report 98-4121, 25 p.

Hill, M.C., 1990, Preconditioned conjugate-gradient 2 (PCG2), A computer program for solving ground-water flow equations: U.S. Geological Survey Water-Resources Investigations Report 90-4048, 43 p.

Holland, T.W., 2007, Water use in Arkansas, 2005: U.S. Geological Survey Scientific Investigations Report 2007-5241, 32 p.

Holman, I.P., 2006, Climate change impacts on ground-water recharge-Uncertainty, shortcomings, and the way forward?: Hydrogeology Journal, v. 14, no. 5, p. 637-647.

Hosman, R.L., 1996, Regional stratigraphy and subsurface geology of Cenozoic deposits, Gulf Coastal Plain, southcentral United States: U.S. Geological Survey Professional Paper 1416-G, $35 \mathrm{p}$.

Hosman, R.L., and Weiss, J.S., 1991, Geohydrologic units of the Mississippi embayment and Texas coastal uplands aquifer systems, south-central United States: U.S. Geological Survey Professional Paper 1416-B, 19 p.

Hutson, S.S., Barber, N.L., Kenny, J.F., Linsey, K.S., Lumia, D.S., and Maupin, M.A., 2004, Estimated use of water in the United States in 2000: U.S. Geological Survey Circular $1268,46 \mathrm{p}$.

Intergovernmental Panel on Climate Change (IPCC), 2007, Climate change 2007: Synthesis report: An assessment of the Intergovernmental Panel on Climate Change, $73 \mathrm{p}$.

Johnson, P.M., 1993, Total water withdrawals in Mississippi, 1990: U.S. Geological Survey Open-File Report 93-375, 67 p.

Justus, B.G., 2003, An index of ecological integrity for the Mississippi Alluvial Plain Ecoregion: index development and relations to selected landscape variables: U.S. Geological Survey Water-Resources Investigations Report 20034110, $32 \mathrm{p}$.
Kenny, J.F., Barber, N.L., Hutson, S.S., Linsey, K.S., Lovelace, J.K., and Maupin, M.A., 2009, Estimated use of water in the United States in 2005: U.S. Geological Survey Circular 1344, $52 \mathrm{p}$.

Kilpatrick, J.M., 1992, Simulated response to future pumping in the Sparta aquifer, Union County, Arkansas: U.S. Geological Survey Water-Resources Investigations Report 91-4161, $25 \mathrm{p}$.

Kleiss, B.A., Coupe, R.H., Gonthier, G.J., and Justus, B.J., 2000, Water quality in the Mississippi Embayment, Mississippi, Louisiana, Arkansas, Missouri, Tennessee, and Kentucky,1995-98: U.S. Geological Survey Circular 1208, 36 p., on-line at http://pubs.water.usgs.gov/circ1208/.

Kundzewicz, Z.W., Mata, L.J., Arnell, N.W., Döll, P.,Kabat, P., Jiménez, B., Miller, K.A., Oki, T., Sen, Z., and Shiklomanov, I.A., 2007, Freshwater resources and their management. in Parry, M.L., Canziani, O.F., Palutikof, J.P, van der Linden, P.J. and Hanson, C.E., eds., Climate Change 2007: Impacts, adaptation and vulnerability. Contribution of Working Group II to the Fourth Assessment Report of the Intergovernmental Panel on Climate Change: Cambridge University Press, Cambridge, UK, p. 173-210.

Lloyd, O.B., Jr., and Lyke, W.L., 1995, Ground water atlas of the United States: Segment 10, Illinois, Indiana, Kentucky, Ohio, Tennessee: U.S. Geological Survey Hydrologic Atlas 730-K.

Loáiciga, H.A., Valdes, J.B., Vogel, R., Garvey, J., and Schwartz, H., 1996, Global warming and the hydrologic cycle: Journal of Hydrology, v. 174, no. 1-2, p. 83-127.

Mahon, G.L., and Ludwig, A.H., 1990, Simulation of groundwater flow in the Mississippi River alluvial aquifer in eastern Arkansas: U.S. Geological Survey Water-Resources Investigations Report 89-4145, $57 \mathrm{p}$.

Mahon, G.L., and Poynter, D.T., 1993, Development, calibration, and testing of ground-water flow models for the Mississippi River Valley alluvial aquifer in eastern Arkansas using one-square-mile cells: U.S. Geological Survey WaterResources Investigations Report 92-4106, 33.

Mantua, N.J., and Hare, S.R., 2002, The Pacific decadal oscillation: Journal of Oceanography, v. 58, no. 1, p. 35-44.

Martin, Angel, Jr., and Whiteman, C.D., Jr., 1999, Hydrology of the coastal lowlands aquifer system in parts of Alabama, Florida, Louisiana, and Mississippi: U.S. Geological Survey Professional Paper 1416-H, 51 p., 8 pls.

Maupin, M.A., and Barber, N.L., 2005, Estimated withdrawals from principal aquifers in the United States, 2000: U.S. Geological Survey Circular 1279, 46 p. 
McCabe, G.J., Palecki, M.A., and Betancourt, J.L., 2004, Pacific and Atlantic ocean influence on multidecadal drought frequency in the United States: Proceedings of the National Academy of Sciences USA, v. 101, p. 4,1364,141 .

McKee, P.W., and Clark, B.R., 2003, Development and calibration of a ground-water flow model for the Sparta aquifer of southeastern Arkansas and north-central Louisiana and simulated response to withdrawals, 1998-2027: U.S. Geological Survey Water-Resources Investigations Report 03-4132, 71 p.

McWreath, H.C., III, Nelson, J.D., and Fitzpatrick, D.J., 1991, Simulated response to pumping stresses in the Sparta aquifer, northern Louisiana and southern Arkansas: Louisiana Department of Transportation and Development Water Resources Technical Report No. 51, 51 p.

Mehl, S.W., and Hill, M.C., 2007, MODFLOW-2005, The U.S. Geological Survey modular ground-water modelDocumentation of the multiple-refined-areas capability of Local Grid Refinement (LGR) and the Boundary Flow and Head (BFH) Package: U.S. Geological Survey Techniques and Methods, book 6, chap. A21, 13 p.

Milly, P.C.D., Dunne, K.A., and Vecchia, A.V., 2005, Global pattern of trends in streamflow and water availability in a changing climate: Nature, v. 438, p. 347-350.

Minobe, Shoshiro, 1997, A 50-70 year climate oscillation over the North Pacific and North America: Geophysical Research Letters, v. 24, p. 683-686.

National Drought Mitigation Center, 2010, Understanding ENSO and forecasting drought, accessed May 27, 2010, at http://www.drought.unl.edu/.

National Oceanic and Atmospheric Administration, 2009a, NOAA Southern Regional Climate Center, accessed January 13, 2009, at http://www.srcc.lsu.edu/.

National Oceanic and Atmospheric Administration, 2009b, United States Historical Climatology Network (USHCN), accessed January 27, 2009, at http://www.ncdc.noaa.gov/oa/ climate/research/ushcn/ushcn.html.

Payne, J.N., 1968, Hydrologic significance of the lithofacies of the Sparta Sand in Arkansas, Louisiana, Mississippi, and Texas: U.S. Geological Survey Professional Paper 569-A, 17 p.

Prudic, D.E., Konikow, L.F., and Banta, E.R., 2004, A new streamflow-routing (SFR1) package to simulate streamaquifer interaction with MODFLOW-2000: U.S. Geological Survey Open-File Report 2004-1042, 95 p.
Reed, T.B., 2003, Recalibration of a ground-water flow model of the Mississippi River Valley alluvial aquifer of northeastern Arkansas, 1918-1998, with simulations of water levels caused by projected ground-water withdrawals through 2049: U.S. Geological Survey Water-Resources Investigations Report 2003-4109, 58 p.

Reed, J.E., 1972, Analog simulation of water-level declines in the Sparta Sand, Mississippi embayment: U.S. Geological Survey Hydrologic Atlas, HA 434, 5 maps.

Renken, R.A., 1998, Groundwater atlas of the United States: Segment 5, Arkansas, Louisiana, Mississippi: U.S. Geological Survey Hydrologic Atlas 730-F, 1 atlas.

Ryder, P.D., and Ardis, A.F., 2002, Hydrology of the Texas gulf coast aquifer systems: U.S. Geological Survey Professional Paper 1416-E.

Sargent, P.B., 2007, Water use in Louisiana, 2005: Louisiana Department of Transportation and Development Water Resources Special Report No. 16, 133 p.

Schrader, T.P., 2004, Status of water levels and selected water-quality conditions in the Sparta-Memphis aquifer in Arkansas and the Sparta aquifer in Louisiana, spring-summer 2001: U.S. Geological Survey Scientific Investigations Report 2004-5055, 57 p.

Schrader, T.P., 2006, Status of water levels and selected waterquality conditions in the Mississippi River Valley alluvial aquifer in eastern Arkansas, 2004: U.S. Geological Survey Scientific Investigations Report 2006-5128, 82 p.

Schrader, T.P., 2007, Potentiometric surface in the SpartaMemphis aquifer of the Mississippi Embayment, spring 2007: U.S. Geological Survey Scientific Investigations Map 3014, 1 sheet.

Schrader, T.P., 2008, Water levels and selected water-quality conditions in the Mississippi River Valley alluvial aquifer in eastern Arkansas, 2006: U.S. Geological Survey Scientific Investigations Report 2008-5092, 73 p.

Schrader, T.P., and Jones, J.S., 2007, Status of water levels and selected water-quality conditions in the Sparta-Memphis aquifer in Arkansas and the status of water levels in the Sparta aquifer in Louisiana, spring 2005: U.S. Geological Survey Scientific Investigations Report 2007-5029, $66 \mathrm{p}$.

Sherif, M.M., and Singh, V.P., 1999, Effect of climate change on sea water intrusion in coastal aquifers: Hydrologic Processes, v. 13, no. 8, p. 1,277-1,287. 
Shun, T., and Duffy, C.J., 1999, Low-frequency oscillations in precipitation, temperature, and runoff on a west facing mountain front: A hydrogeologic interpretation: Water Resources Research, v. 35, p. 191-201.

Stanton, G.P., 1997, Potentiometric surface and specific conductance of the Sparta and Memphis aquifers in eastern Arkansas, 1995: U.S. Geological Survey Water-Resources Investigations report 97-4119, $16 \mathrm{p}$.

Stanton, G.P., and Clark, B.R., 2003, Recalibration of a ground-water flow model of the Mississippi River Valley alluvial aquifer in southeastern Arkansas, 1918-1998, with simulations of hydraulic heads caused by projected ground-water withdrawals through 2049: U.S. Geological Survey Water-Resources Investigations Report 03-4232, $48 \mathrm{p}$.

Stephenson, L.W., Logan, W.N., Waring, G.A., and Howard, C.S., 1928, The ground-water resources of Mississippi, with discussions of the chemical character of the waters: U.S. Geological Survey Water-Supply Paper 576, 515 p.

Stuart, M., Klotz, C., and Kascak, C., 1996, Agricultural resources and environmental indicators: U.S. Department of Agriculture Economic Research Service, Number 17, 4 p.

Sumner, D.M., and Wasson, B.E., 1990, Geohydrology and simulated effects of large ground-water withdrawals on the Mississippi River alluvial aquifer in northwestern Mississippi: U.S. Geological Survey Water-Supply Paper 2292, $60 \mathrm{p}$.

Tele Atlas North America, Inc., 2008, U.S. census block groups: ESRI Data \& Maps, Redlands, California, vector digital data.

Tonkin, M.J., Tiedeman, C.R., Ely, D.M., and Hill, M.C., 2007, OPR-PPR, a computer program for assessing data importance to model predictions using linear statistics: U.S. Geological Survey Techniques and Methods Report, book 6, chap. E2, 115 p.

U.S. Army Corp of Engineers, 2009, Grand Prairie Area Demonstration Project, accessed February 23, 2009, at http://www. mvm.usace.army.mil/grandprairie/overview/default.asp.

U.S. Department of Agriculture, 2010, The census of agriculture - 2007 census publications, accessed July 8, 2010, at http://www.agcensus.usda.gov/Publications/2007/Online_ Highlights/County_Profiles/index.asp.

U.S. Census Bureau, 2009, Population finder, accessed November 11, 2009, at http://factfinder.census.gov/.
U.S. Geological Survey, 2002, Concepts for national assessment of water availability and use: U.S. Geological Survey Circular 1223, 34 p.

U.S. Geological Survey, 2008a, Office of Ground Water (OGW), accessed October 15, 2008, at http://water.usgs. gov/cgi/rasabiblio/?category $=11 \&$ form $=$ introduction .

U.S. Geological Survey, 2008b, The USGS Land Cover Institute (LCI), accessed October 15, 2008, at http://landcover. usgs.gov/natllandcover.php.

U.S. Geological Survey, 2009, USGS water data for the Nation, accessed November 13, 2009, at http://waterdata. usgs.gov/nwis.

U.S. Geological Survey, 2010a, Estimated use of water in the United States, County-level data for 2005, accessed January 6, 2010, at http://water.usgs.gov/watuse/data/2005/ index.html.

U.S. Geological Survey, 2010b, Groundwater levels for the Nation: accessed January 12, 2010, at http://nwis.waterdata. usgs.gov/usa/nwis/gwlevels/?site_no $=330448090192201$.

U.S. Geological Survey, 2010c, USGS Arkansas Water Science Center, water-use science program, accessed July 12, 2010, at http://ar.water.usgs.gov/wateruse.html.

U.S. Global Change Research Program, 2010, U.S. National assessment of the potential consequences of climate variability and change, Educational Resources regional paper: The Southeast, accessed May 27, 2010, at http://www. usgcrp.gov/usgcrp/nacc/education/southeast/se-edu-2.htm.

Vautard, R., Yiou, P., and Ghil, M., 1992, Singular-spectrum analysis: A toolkit for short, noisy chaotic signals: Physica D, v. 58, p. $95-126$.

Veatch, A.C., 1906, Geology and underground water resources of northern Louisiana and southern Arkansas: U.S. Geological Survey Professional Paper 46, 422 p.

Weiss, J.S., 1992, Geohydrologic units of the coastal lowlands aquifer system, south-central United States: U.S. Geological Survey Professional Paper 1416-C, 32 p.

Williams, A.K., 2001, Ground-water flow in the gulf coast aquifer systems, south-central United States: U.S. Geological Survey Professional Paper 1416-F.

Williams, T.A., and Williamson, A.K., 1989, Estimating watertable altitudes for regional ground-water flow modeling, U.S. Gulf Coast: Ground Water, v. 27, no. 3, p. 333-340. 
Winter, T.C., Harvey, J.W., Franke, O.L., and Alley, W.M., 1998, Ground water and surface water; a single resource: U.S. Geological Survey Circular 1139, 79 p.

Wolter, Klaus, and Timlin, M.S., 1993, Monitoring ENSO in COADS with a seasonally adjusted principal component index, in Proceedings of the 17th Climate Diagnostics Workshop, Norman, Okla, NOAA/NMC/CAC, NSSL: Oklahoma Climate Survey, CIMMS and the School of Meteorology, University of Oklahoma, p. 52-57.
Wolter, Klaus, and Timlin, M.S., 1998, Measuring the strength of ENSO events-How does 1997/98 rank?: Weather, v. 53, no. 9, p. 315-324.

Yazoo Mississippi Delta Joint Water Management District, 2008, 2008 Annual Report, accessed online September 4, 2009, at $h t t p: / / y m d . o r g / p d f s / 2008$ annualreportfinal. $p d f$. 
Appendixes 1-3 


\section{Appendix 1. Effects of Natural-Climate Trends on Interannual to Multidecadal Timescales}

To best understand the potential consequences of climate trends, research needs to address the effects from natural climate patterns on interannual to multidecadal timescales, which are major obstacles to the reliable characterization of global climate trends resulting from human activities (Ghil, 2002). Interannual to multidecadal natural climate trends across the United Staes are affected by various ocean-atmospheric phenomenon, including the El Niño Southern Oscillation (ENSO), Pacific Decadal Oscillation (PDO), and Atltantic Multidecadal Oscillation (AMO) (Gurdak and others, 2009). Climate variability on these timescales may have a substantial influence on spatiotemporal patterns in precipitation, drought, evapotranspiration, streamflow, and groundwater recharge and discharge (Hanson and others, 2004).

ENSO is a coupled ocean-atmospheric phenomenon that has interannual variability with irregular 2- to 6-year cycles between the positive (El Niño) and negative (La Niña) phases (fig. 1-1A) (Wolter and Timlin, 1993, 1998). The El Niño generally results in relatively heavier precipitation during winter for parts of the United States that include the MERAS study area, and the La Niña generally results in drier conditions for parts of the United States that include the MERAS study area (Wolter and Timlin, 1993, 1998).
PDO is an ENSO-like pattern of Pacific Ocean climate variability that affects winter air temperatures and precipitation in the United States and has interdecadal variability with irregular 10- to 25-year cycles (fig. 1-1B) (Mantua and Hare, 2002). PDO was in the positive phase from 1925 to 1946 and 1977 to 1999 and the negative phase from the early 1900 s to 1924 and 1947 to 1976 (fig. 1-1B) (Mantua and Hare, 2002). PDO is currently (2010) in the negative phase, which has been associated with drought conditions across much of the United States (McCabe and others, 2004).

Periods of climate variability greater than 25 years are referred to as greater than PDO (Hanson and others, 2004, 2006; Gurdak and others, 2007). The greater than PDO cycles may be attributed to longer PDO fluctuations with periodicities of 50 to 70 years (Minobe, 1997) or variations in the AMO. However, the sources and stationarity of the greater than PDO forcings remain uncertain. The AMO is an index of sea-surface temperatures averaged over the North Atlantic Ocean with irregular 50- to 80-year cycles (fig. 1-1C) that has a strong influence on summer precipitation and drought frequency in the United States (Enfield and others, 2001). AMO was in the positive phases from 1860 to 1880 and 1930 to 1960 , and the negative phases from 1905 to 1925 and 1970

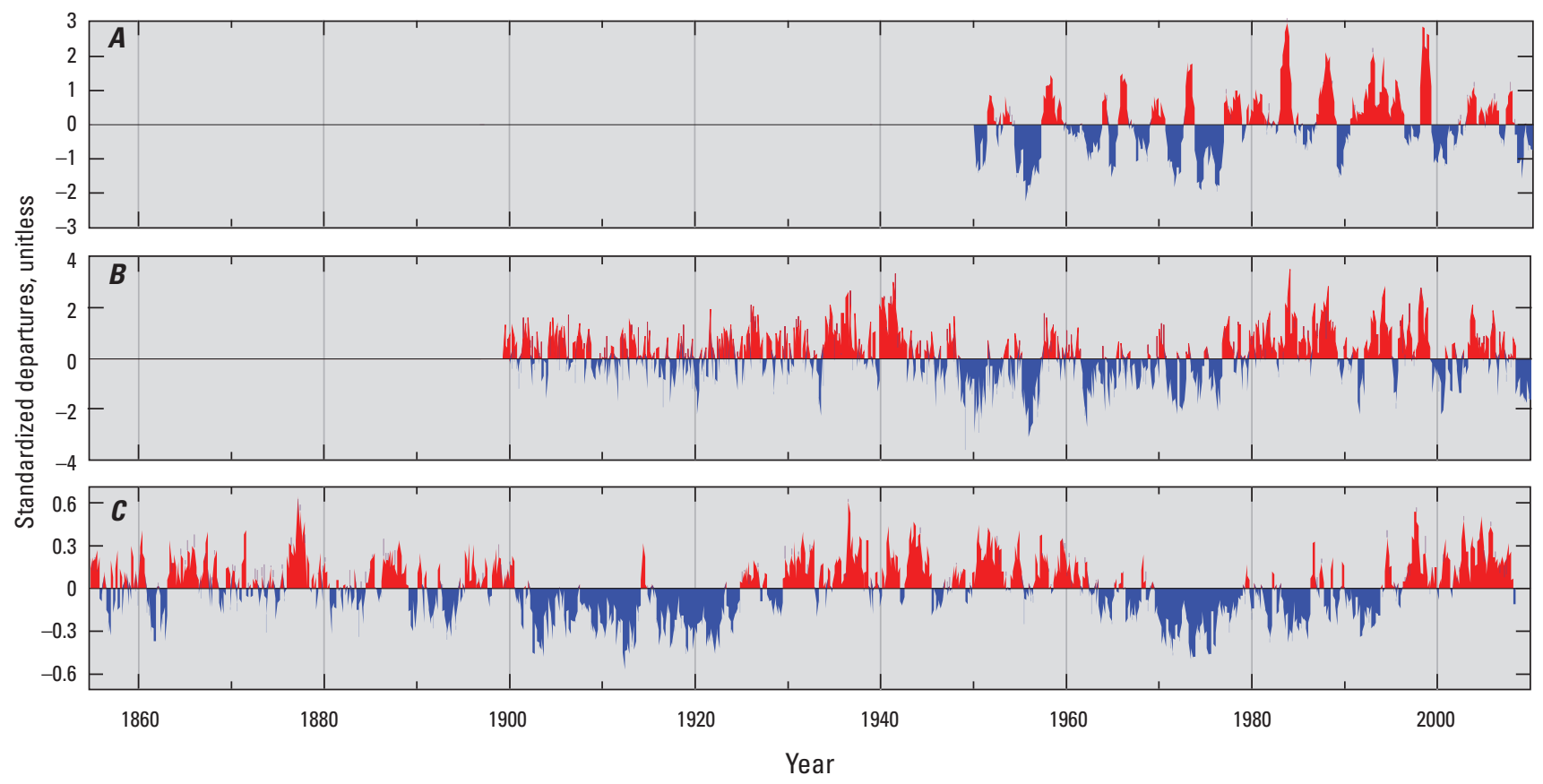

Figure 1-1. Interactions between the positive (red) and negative (blue) phases of the $A$, multivariate El Niño/Southern Oscillation (ENSO) index (Wolter and Timlin, 1993, 1998), B, Pacific Decadal Oscillation (PDO) index (Mantua and Hare, 2002), and C, Atlantic Multidecadal Oscillation (AMO) index (Enfield and others, 2001) cumulatively affect United States climate and, in turn, surface and groundwater resources. 
to 1990 (fig. 1-1C). Since 1995, AMO has been in the positive phase, which may result in above-normal frequencies of drought in the United States for the coming decades (McCabe and others, 2004).

Recent research has identified interactions between interannual and multidecadal natural climate trends that cumulatively affect recharge (Dickinson and others, 2004; Hanson and others, 2004, 2006; Gurdak and others, 2007). Groundwater levels can respond dramatically when climate trends from different cycles lie coincident in an increasing (positive or wet/warm) or decreasing (negative or dry/cool) phase of variability that affects recharge and discharge. To demonstrate this phenomenon, Hanson and others (2004) isolated statistically independent oscillatory signals (or cycles) within a synthetic hydrologic time-series record to illustrate the cumulative effect of the independent signals on the time series. In the example, Hanson and others (2004) identified 10-, 6-, and 1-year oscillatory signals that contributed $81.0,13.1$, and 3.2 percent of the variances of the synthetic time series, respectively (Hanson and others, 2004). The annual signal in the example is less evident during periods of decreasing (negative) variation of the 10-year signal; such as around 1907 (see figs. 2 and 3 of Hanson and others, 2004). Furthermore, drought conditions may exist around 1917 in this example because all three signals are in decreasing (negative) phases (see figs. 2 and 3 of Hanson and others, 2004). Conversely, the annual signal is magnified if the 10- and 6-year signals are in an increasing (positive) phase of variation, such as around 1913, and may result in flooding conditions (see figs. 2 and 3 of Hanson and others, 2004).

Gurdak and others (2007) present a real-world example of the cumulative effect of statistically independent oscillatory signals on groundwater levels in the High Plains aquifer, which covers parts of eight Western States in the Great Plains physiographic province of the United States. In the High Plains aquifer study, statistically independent ENSO and PDO signals in the groundwater levels were found to be partially dampened or accentuated by groundwater pumping and other climate forcings on interannual to multidecadal time scales, such as ENSO, PDO, and AMO (see fig. 9 of Gurdak and others, 2007). For example, the amplitude of ENSO signals in the groundwater levels generally was dampened during the negative PDO periods, especially from the mid-1940s to mid-1970s (see fig. 9 of Gurdak and others, 2007). Therefore, awareness of natural-climate spatiotemporal trends and interactions and human stresses on the aquifer system can play a crucial role in successful modeling and management of groundwater resources (Hanson and others, 2004). 


\section{Appendix 2. Singular Spectrum Analysis}

The singular spectrum analysis method is a widely used form of principal-component analysis in lag-time domain that uses a data-adaptive signal-to-noise enhancement to detect periodic signals in short, noisy time series (Vautard and others, 1992). The data-adaptive enhancements help separate the time series into reconstructed components that are statistically independent and thus can be classified into trends, oscillatory patterns, and noise (Ghil and others, 2002). The singular spectrum analysis method has been shown to be optimal in the sense of capturing the maximum variance with the fewest independent reconstructed components (Shun and Duffy, 1999). The variability in most hydrologic time series can be adequately described in terms of the first 10 reconstructed components and often takes the form of quasi-periodic or near-sinusoidal oscillations that are related to interannual to multidecadal natural climate variability (Hanson and others, 2004). A Chi-squared significance test (Allen and Smith, 1996; Ghil and others, 2002) was performed on each of the first 10 reconstructed components to test their individual significance against a red-noise null-hypothesis at the 95-percent confidence level. Statistically significant reconstructed components from time series at the wells, meteorological stations, and streamflow-gaging stations are listed in table 2-1.

The results of the singular spectrum analysis indicate that all the time series from the selected groundwater-level sites, meteorological stations, and streamflow-gaging stations contain variations within the ranges consistent with ENSO, PDO, and greater than PDO (fig. 2-1A-C and table 2-1). Other reconstructed components were identified between the known ENSO and PDO cycles with periodicities between 6 and 10 years (fig. 2-1A-C and table 2-1). The specific cause of variations in hydrologic time series with periodicities of 6 to 10 years remains uncertain. Hanson and others (2004) noted that these variations may be related to a periodic persistence of northerly movement of subtropical moisture from the Gulf of Mexico or from the Pacific Ocean, which may be caused by the North American Monsoon System (NAMS). However, Fye and others (2006) identified 7- to 8-year periodicities in precipitation variability across North America that may originate from the North Atlantic Oscillation. The 6- to 10-year cycles identified in the MERAS area have variance generally less than 20 and 30 percent in the precipitation and streamflow time series, respectively, but contain up to 60 percent of the variance in select reconstructed components of the groundwater levels (fig. $2-1 A-C$ ). The uncertain origin of the 6- to 10 -year forcings and the relative strength of these signals in groundwater levels indicates that further study is needed to better understand the processes causing these relatively important variations in MERAS groundwater levels.

The majority of the variance in the precipitation time series was attributed to greater than PDO (greater than 25 years) and PDO periods (10 to 25 years), capturing approximately 10 to 80 percent and 10 to 70 percent of the variance, respectively (fig. 2-1A). The greater than PDO and PDO climatic forcings apparently have more control on precipitation variability in the MERAS than the higher-frequency forcings, such as NAMS and ENSO. Lower-frequency periodicities in the precipitation time series cluster around 20.8, 27.8, and 41.7 years (fig. $2-1 A$ ), which are similar to the approximate 20- to 22- and 28-year periodicities previously indentified in precipitation time series of the High Plains aquifer of the central United States and identified as related to PDO and AMO variability (Gurdak and others, 2007).

McCabe and others (2004) showed that spatio-temporal patterns in precipitation variability and drought frequency (in percent of years) across the conterminous United States can be attributed to the interactions between the PDO and AMO phases of variability. ENSO variability can also augment or diminish the cumulative effect of PDO and AMO on MERAS precipitation. McCabe and others (2004) found that much of the United States has a relatively low drought frequency during the positive PDO and negative AMO phases, which is observed as relatively high average annual precipitation in the MERAS such as during the positive PDO and negative AMO phases of the late 1970s and early 1980s (fig. $1-1 B-C$ and fig. 22). The moderate El Niño of these periods may help to augment average annual precipitation in MERAS (fig. 1-1A). During the negative PDO and negative AMO phases, McCabe and others (2004) identified higher drought frequency across parts of the United States, including parts of the Great Plains physiographic province and the southwestern part of MERAS in the West Gulf Coastal Plain physiographic section (fig. 1), and relatively lower drought frequency across the eastern part of the MERAS in the East Gulf Coastal Plain physiographic section (fig. 1). The spatio-temporal response in precipitation to the negative PDO and negative AMO phases (fig. $21 B-C$ ) is illustrated during the mid-1960s and the early- to mid1970s as relatively low average annual precipitation at the El Dorado and western precipitation sites and relatively high average annual precipitation for the Jackson and Memphis precipitation sites in eastern MERAS (fig. 22). Conversely, the opposite spatio-temporal patterns were identified by McCabe and others (2004) during the positive PDO and positive AMO that results in lower drought frequency in the southwestern part of MERAS in the West Gulf Coastal Plain physiographic section (fig. 1), and relatively higher drought frequency across the eastern part of the MERAS in the East Gulf Coastal Plain physiographic section (fig. 1). The spatio-temporal response of precipitation in the MERAS (fig. 22) is not entirely consistent with McCabe and other's (2004) United States drought frequency patterns during the positive $\mathrm{PDO}$ and positive AMO phases (fig. $1-1 B-C$ ). For example, during the positive PDO and positive AMO phases of the late-1950s to early-1960s, late-1990s, and around 2005, the average annual precipitation 
Table 2-1. Summary of the period and percent variance for reconstructed components from the singular spectrum analysis.

[--, reconstructed components were not estimated based on Chi-squared significance test; darker shaded cells have periods consistent with greater than Pacific Decadal Oscillation (greater than 25 years); lighter shaded cells have periods consistent with Pacific Decadal Oscillation (10 to 25 years); thicker bounded cells have periods between 6 and 10 years; thinner bounded cells have periods consistent with El Niño Southern Oscillation (2 to 6 years)]

\begin{tabular}{|c|c|c|c|c|c|c|c|c|c|c|c|c|c|}
\hline \multirow{2}{*}{$\begin{array}{c}\text { Site } \\
\text { number }\end{array}$} & \multirow{2}{*}{$\begin{array}{l}\text { Start } \\
\text { year }\end{array}$} & \multirow{2}{*}{$\begin{array}{l}\text { End } \\
\text { year }\end{array}$} & \multirow{2}{*}{$\begin{array}{c}\text { Number } \\
\text { of } \\
\text { years }\end{array}$} & \multicolumn{10}{|c|}{ Period, in years (percent variance) of reconstructed components from the singular spectrum analysis } \\
\hline & & & & 1 & 2 & 3 & 4 & 5 & 6 & 7 & 8 & 9 & 10 \\
\hline \multicolumn{14}{|c|}{ Precipitation sites } \\
\hline 11084 & 1904 & 1994 & 90 & $\begin{array}{c}27.8 \\
(72.1)\end{array}$ & -- & -- & $\begin{array}{c}6.0 \\
(0.5)\end{array}$ & $\begin{array}{c}4.6 \\
(0.3)\end{array}$ & $\begin{array}{c}3.6 \\
(0.3)\end{array}$ & $\begin{array}{c}2.8 \\
(0.2)\end{array}$ & $\begin{array}{c}2.6 \\
(0.2)\end{array}$ & $\begin{array}{c}2.2 \\
(0.1)\end{array}$ & -- \\
\hline 12813 & 1918 & 1994 & 76 & $\begin{array}{c}27.8 \\
(70.0)\end{array}$ & $\begin{array}{c}20.8 \\
(19.6)\end{array}$ & -- & $\begin{array}{c}4.9 \\
(1.8) \\
\end{array}$ & $\begin{array}{c}4.0 \\
(1.3)\end{array}$ & $\begin{array}{c}2.8 \\
(0.6)\end{array}$ & $\begin{array}{c}2.5 \\
(0.6)\end{array}$ & $\begin{array}{c}2.1 \\
(0.5)\end{array}$ & -- & -- \\
\hline 13160 & 1893 & 1994 & 101 & $\begin{array}{c}27.8 \\
(52.1)\end{array}$ & -- & $\begin{array}{c}8.3 \\
(6.9) \\
\end{array}$ & $\begin{array}{c}6.9 \\
(3.7) \\
\end{array}$ & $\begin{array}{c}4.9 \\
(1.5)\end{array}$ & $\begin{array}{c}4 \\
(1.4)\end{array}$ & $\begin{array}{c}3.3 \\
(1.1)\end{array}$ & $\begin{array}{c}3.0 \\
(0.5)\end{array}$ & -- & -- \\
\hline 15749 & 1940 & 1994 & 54 & $\begin{array}{c}20.8 \\
(68.7)\end{array}$ & -- & $\begin{array}{c}5.2 \\
(2.9) \\
\end{array}$ & $\begin{array}{c}3.6 \\
(1.6) \\
\end{array}$ & $\begin{array}{c}2.7 \\
(1.1)\end{array}$ & $\begin{array}{c}2.2 \\
(0.7)\end{array}$ & -- & -- & $\begin{array}{c}1.7 \\
(0.4)\end{array}$ & $\begin{array}{c}1.6 \\
(0.3) \\
\end{array}$ \\
\hline 17366 & 1882 & 1994 & 112 & $\begin{array}{c}27.8 \\
(42.6)\end{array}$ & $\begin{array}{c}20.8 \\
(35.5)\end{array}$ & $\begin{array}{c}9.3 \\
(9.9)\end{array}$ & $\begin{array}{c}7.6 \\
(3.9)\end{array}$ & $\begin{array}{c}5.6 \\
(1.6)\end{array}$ & $\begin{array}{c}4.4 \\
(1.0)\end{array}$ & $\begin{array}{c}3.6 \\
(0.8)\end{array}$ & $\begin{array}{c}3.2 \\
(0.6)\end{array}$ & $\begin{array}{c}2.8 \\
(0.4)\end{array}$ & $\begin{array}{c}2.5 \\
(0.4)\end{array}$ \\
\hline 31632 & 1892 & 1994 & 102 & $\begin{array}{c}20.8 \\
(42.9)\end{array}$ & -- & $\begin{array}{c}8.3 \\
(10.4) \\
\end{array}$ & -- & $\begin{array}{c}4.9 \\
(2.2)\end{array}$ & $\begin{array}{c}4.2 \\
(1.0)\end{array}$ & $\begin{array}{c}3.5 \\
(0.7)\end{array}$ & $\begin{array}{c}3.0 \\
(0.4)\end{array}$ & $\begin{array}{c}2.1 \\
(0.3)\end{array}$ & $\begin{array}{c}2.3 \\
(0.3)\end{array}$ \\
\hline 34572 & 1904 & 1994 & 90 & $\begin{array}{c}16.7 \\
(28.1)\end{array}$ & $\begin{array}{c}11.9 \\
(27.5)\end{array}$ & $\begin{array}{c}7.6 \\
(15.8) \\
\end{array}$ & $\begin{array}{c}5.6 \\
(6.8) \\
\end{array}$ & $\begin{array}{c}4.4 \\
(4.4) \\
\end{array}$ & $\begin{array}{c}3.6 \\
(3.4) \\
\end{array}$ & $\begin{array}{c}3.0 \\
(2.1) \\
\end{array}$ & $\begin{array}{c}2.6 \\
(1.3) \\
\end{array}$ & $\begin{array}{c}2.3 \\
(1.1) \\
\end{array}$ & $\begin{array}{c}2.0 \\
(1.0)\end{array}$ \\
\hline 34756 & 1887 & 1994 & 107 & $\begin{array}{c}41.7 \\
(56.8)\end{array}$ & -- & $\begin{array}{c}9.3 \\
(6.8) \\
\end{array}$ & -- & $\begin{array}{c}5.2 \\
(1.9)\end{array}$ & $\begin{array}{c}4.2 \\
(1.3)\end{array}$ & $\begin{array}{c}3.6 \\
(0.9)\end{array}$ & $\begin{array}{c}3.0 \\
(0.5)\end{array}$ & $\begin{array}{c}2.8 \\
(0.4)\end{array}$ & -- \\
\hline 35754 & 1884 & 1994 & 110 & $\begin{array}{l}27.8 \\
(49)\end{array}$ & $\begin{array}{c}20.8 \\
(27.6)\end{array}$ & $\begin{array}{c}8.3 \\
(6.1) \\
\end{array}$ & -- & $\begin{array}{c}4.9 \\
(3.8)\end{array}$ & -- & $\begin{array}{c}3.6 \\
(1.3)\end{array}$ & $\begin{array}{c}3.2 \\
(0.7)\end{array}$ & $\begin{array}{c}2.8 \\
(0.4)\end{array}$ & $\begin{array}{c}2.5 \\
(0.3)\end{array}$ \\
\hline 35908 & 1882 & 1994 & 112 & $\begin{array}{c}41.7 \\
(60.8)\end{array}$ & $\begin{array}{c}16.7 \\
(27.7)\end{array}$ & $\begin{array}{l}10.4 \\
(5.0)\end{array}$ & $\begin{array}{c}7.6 \\
(2.2)\end{array}$ & $\begin{array}{c}5.6 \\
(1.1)\end{array}$ & $\begin{array}{c}4.6 \\
(0.7)\end{array}$ & $\begin{array}{c}3.8 \\
(0.4)\end{array}$ & $\begin{array}{c}3.2 \\
(0.3)\end{array}$ & $\begin{array}{c}2.8 \\
(0.2)\end{array}$ & $\begin{array}{c}2.5 \\
(0.2)\end{array}$ \\
\hline 160537 & 1894 & 1994 & 100 & $\begin{array}{c}27.8 \\
(40.6)\end{array}$ & $\begin{array}{c}16.7 \\
(28.3)\end{array}$ & $\begin{array}{c}8.3 \\
(10.5)\end{array}$ & -- & -- & -- & -- & $\begin{array}{c}3.0 \\
(0.8)\end{array}$ & $\begin{array}{c}2.4 \\
(0.6)\end{array}$ & -- \\
\hline 162151 & 1892 & 1994 & 102 & $\begin{array}{c}27.8 \\
(63.8)\end{array}$ & -- & $\begin{array}{c}9.3 \\
(4.2)\end{array}$ & $\begin{array}{c}6.9 \\
(1.7)\end{array}$ & $\begin{array}{c}4.9 \\
(0.7)\end{array}$ & $\begin{array}{c}4.2 \\
(0.6)\end{array}$ & $\begin{array}{c}3.3 \\
(0.6)\end{array}$ & $\begin{array}{c}2.8 \\
(0.4)\end{array}$ & -- & $\begin{array}{c}2.3 \\
(0.2)\end{array}$ \\
\hline 168163 & 1890 & 1994 & 104 & $\begin{array}{c}41.7 \\
(75)\end{array}$ & -- & $\begin{array}{l}10.4 \\
(3.0)\end{array}$ & $\begin{array}{c}6.9 \\
(1.4) \\
\end{array}$ & $\begin{array}{c}5.2 \\
(0.7)\end{array}$ & $\begin{array}{c}4.2 \\
(0.6)\end{array}$ & $\begin{array}{c}3.5 \\
(0.5)\end{array}$ & -- & -- & $\begin{array}{c}3.0 \\
(0.2)\end{array}$ \\
\hline 231364 & 1882 & 1994 & 112 & $\begin{array}{c}41.7 \\
(61.2)\end{array}$ & -- & $\begin{array}{l}10.4 \\
(4.6)\end{array}$ & $\begin{array}{c}7.6 \\
(1.1) \\
\end{array}$ & $\begin{array}{c}5.6 \\
(0.5) \\
\end{array}$ & $\begin{array}{c}4.6 \\
(0.5) \\
\end{array}$ & $\begin{array}{c}3.8 \\
(0.4)\end{array}$ & $\begin{array}{c}3.1 \\
(0.2)\end{array}$ & $\begin{array}{c}2.8 \\
(0.2)\end{array}$ & $\begin{array}{c}2.5 \\
(0.1)\end{array}$ \\
\hline 232289 & 1904 & 1994 & 90 & $\begin{array}{c}27.8 \\
(46.5)\end{array}$ & $\begin{array}{c}11.9 \\
(22.0)\end{array}$ & -- & -- & -- & -- & -- & $\begin{array}{c}2.6 \\
(0.9) \\
\end{array}$ & $\begin{array}{c}2.3 \\
(0.7) \\
\end{array}$ & $\begin{array}{c}2.0 \\
(0.5) \\
\end{array}$ \\
\hline 232809 & 1878 & 1994 & 116 & $\begin{array}{c}20.8 \\
(30.2)\end{array}$ & -- & $\begin{array}{c}9.3 \\
(18.5)\end{array}$ & -- & $\begin{array}{c}5.6 \\
(3.3)\end{array}$ & $\begin{array}{c}4.6 \\
(1.7)\end{array}$ & $\begin{array}{c}3.8 \\
(1.3)\end{array}$ & $\begin{array}{c}3.3 \\
(1.1)\end{array}$ & $\begin{array}{c}2.9 \\
(0.8)\end{array}$ & $\begin{array}{c}2.0 \\
(0.5)\end{array}$ \\
\hline 235253 & 1893 & 1994 & 101 & $\begin{array}{c}41.7 \\
(60.1)\end{array}$ & $\begin{array}{c}16.7 \\
(22.6)\end{array}$ & $\begin{array}{c}9.3 \\
(7.7) \\
\end{array}$ & -- & $\begin{array}{c}4.9 \\
(1.6) \\
\end{array}$ & $\begin{array}{c}4.0 \\
(0.8)\end{array}$ & $\begin{array}{c}3.5 \\
(0.5) \\
\end{array}$ & $\begin{array}{c}2.9 \\
(0.4) \\
\end{array}$ & $\begin{array}{c}2.6 \\
(0.2) \\
\end{array}$ & $\begin{array}{c}2.1 \\
(0.2) \\
\end{array}$ \\
\hline
\end{tabular}


Table 2-1. Summary of the period and percent variance for reconstructed components from the singular spectrum analysisContinued

[--, reconstructed components were not estimated based on Chi-squared significance test; darker shaded cells have periods consistent with greater than Pacific Decadal Oscillation (greater than 25 years); lighter shaded cells have periods consistent with Pacific Decadal Oscillation (10 to 25 years); thicker bounded cells have periods between 6 and 10 years; thinner bounded cells have periods consistent with El Niño Southern Oscillation ( 2 to 6 years)]

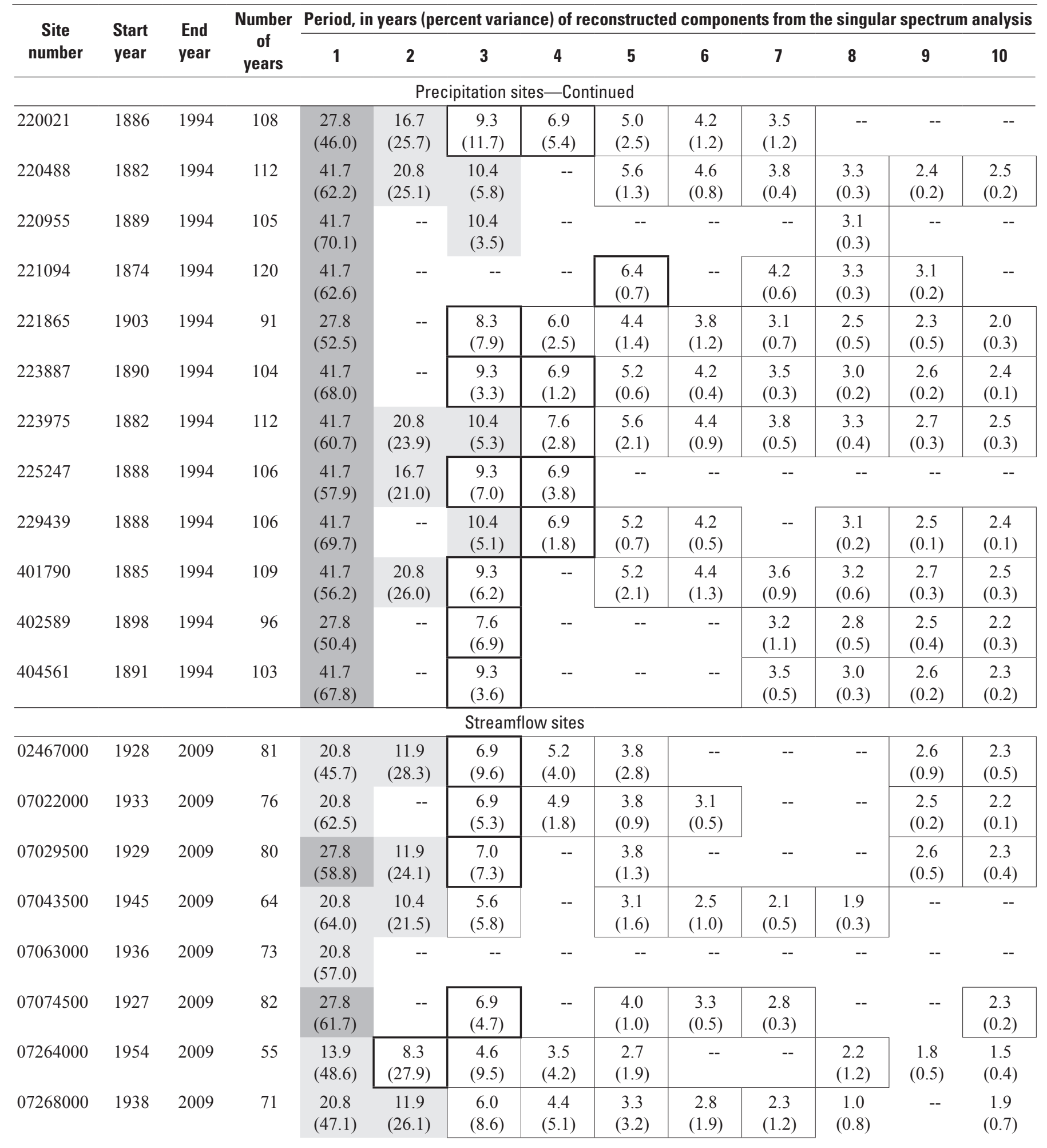


Table 2-1. Summary of the period and percent variance for reconstructed components from the singular spectrum analysisContinued

[--, reconstructed components were not estimated based on Chi-squared significance test; darker shaded cells have periods consistent with greater than Pacific Decadal Oscillation (greater than 25 years); lighter shaded cells have periods consistent with Pacific Decadal Oscillation (10 to 25 years); thicker bounded cells have periods between 6 and 10 years; thinner bounded cells have periods consistent with El Niño Southern Oscillation ( 2 to 6 years)]




Table 2-1. Summary of the period and percent variance for reconstructed components from the singular spectrum analysisContinued

[--, reconstructed components were not estimated based on Chi-squared significance test; darker shaded cells have periods consistent with greater than Pacific Decadal Oscillation (greater than 25 years); lighter shaded cells have periods consistent with Pacific Decadal Oscillation (10 to 25 years); thicker bounded cells have periods between 6 and 10 years; thinner bounded cells have periods consistent with El Niño Southern Oscillation (2 to 6 years)]

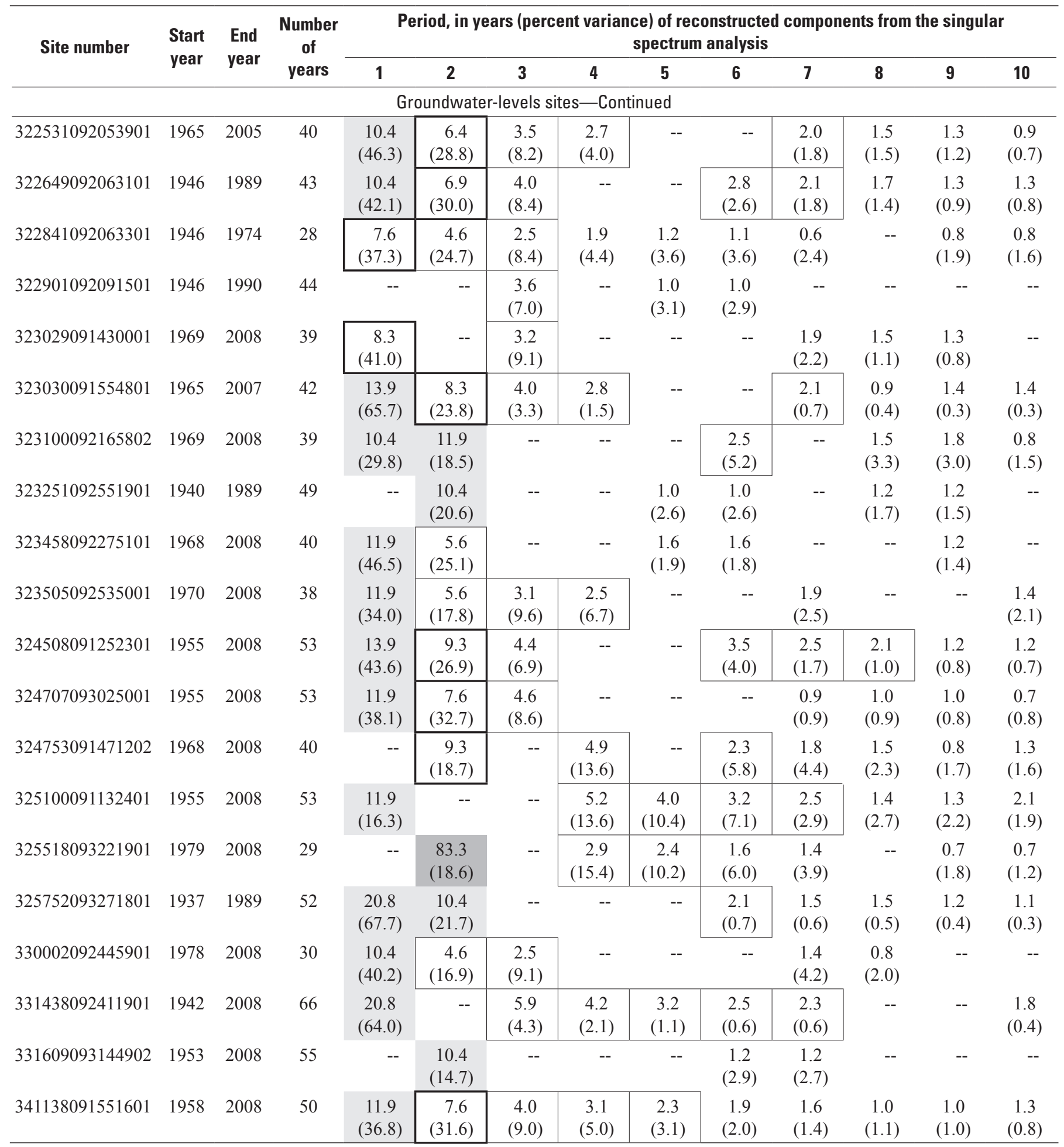




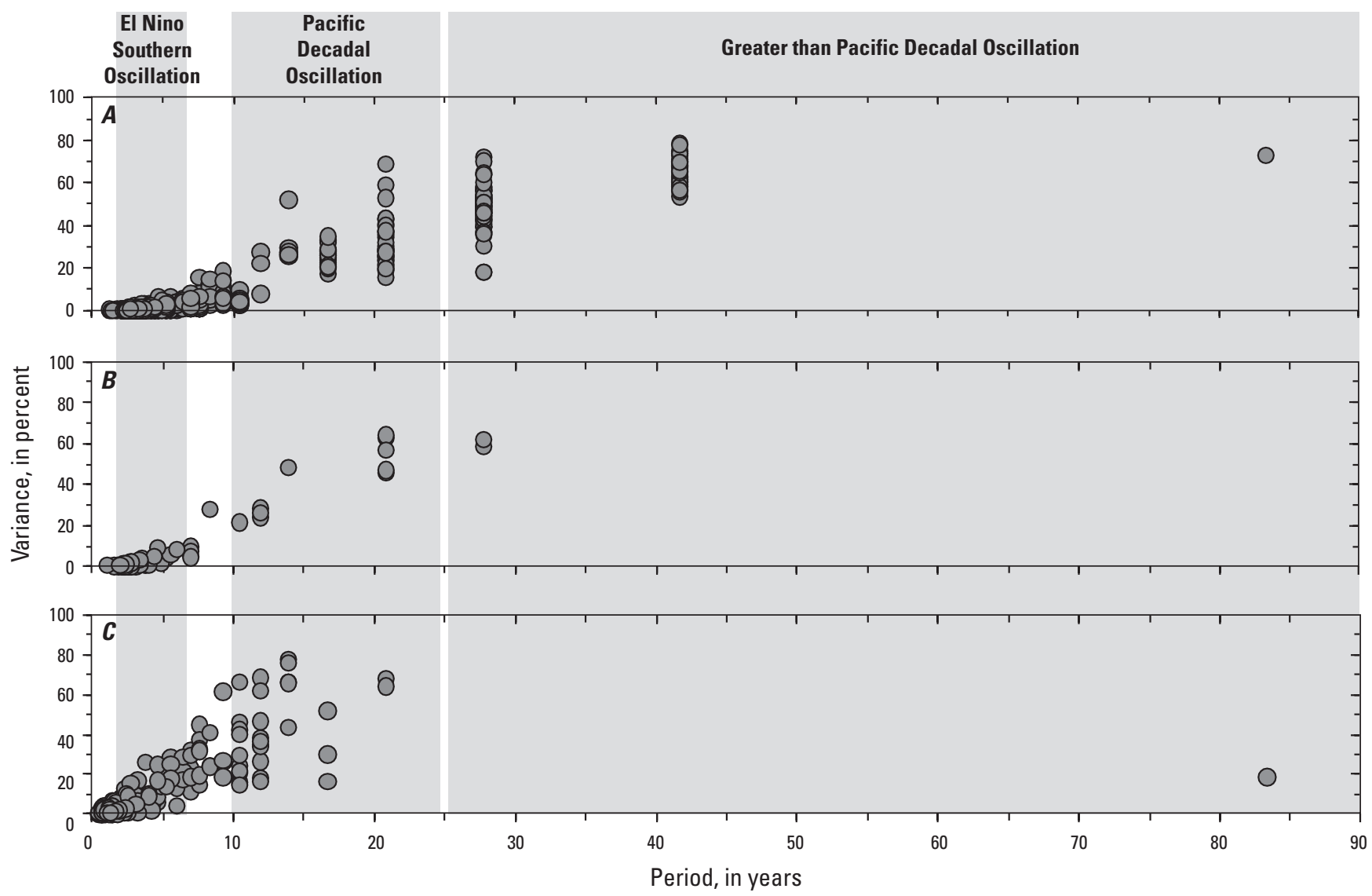

Figure 2-1. Statistically significant reconstructed components based on the Chi-squared significance test from the singular spectrum analysis for time series of $A$, precipitation at meteorological stations, $B$, streamflow at streamflow-gaging stations,

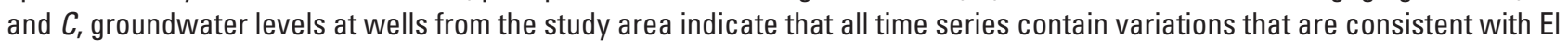
Niño Southern Oscillation (2 to 6 years), Pacific Decadal Oscillation (10 to 25 years), and greater than Pacific Decadal Oscillation (greater than 25 years) periods, which are indicated by the gray shading. Additional variations with periodicities of 6 to 10 years were observed in all three types of hydrologic time series.

was relatively high for much of the MERAS, except for the El Dorado, Jonesboro, and other western sites during late1990s, and around 2005 (fig. 22). During these periods, ENSO was in the El Niño phase, which may help to diminish the drought frequency patterns across parts of the MERAS as identified by McCabe and others (2004). Similar to the positive PDO and positive AMO patterns, McCabe and others (2004) observed that during the negative PDO and positive AMO most of the United States has a relatively higher drought frequency except for the southeastern corner of MERAS area, which was observed to have a lower frequency of drought. The spatiotemporal response in precipitation to the negative PDO and positive AMO phases (fig. $1-1 B-C$ ) is illustrated during the 1950s and from about 2007 to 2010 as having relatively low average annual precipitation at the MERAS sites (fig. 22). During these periods ENSO was in the La Niña phase, which may have augmented the drought frequency patterns across parts of the MERAS as identified by McCabe and others (2004).

The majority of the variance in the streamflow time series was attributed to PDO periods (10 to 25 years), capturing approximately 20 to 70 percent of the variance and having periodicities that cluster around $10.4,11.9$, and 20.8 years (table 2-1 and fig. 2-1B). Two streamflow time series had reconstructed components consistent with greater than PDO (greater than 25 years) capturing approximately 60 percent of the variance and having periodicities at 27.8 years (table $2-1$ and fig. 2-1B). Higher-frequency periodicities also are consistent with the 6- to 10-year period and ENSO (2 to 6 years), but capture less than 25 percent of the variance in the streamflow time series.

The majority of the variance in the groundwater level time series was attributed to PDO periods (10 to 25 years), capturing approximately 20 to 80 percent of the variance, and having periodicities that cluster around 10.4, 11.9, 13.9, 16.7, and 20.8 years (table $2-1$ and fig. $2-1 C$ ). One groundwater level time series had a reconstructed component consistent with greater than PDO (greater than 25 years) capturing approximately 20 percent of the variance and having a periodicity at 83.3 years (table $2-1$ and fig. 2-1C). Higher-frequency periodicities also are consistent with the 6- to 10 -year period and ENSO ( 2 to 6 years) and capture between less than 10 and 60 percent of the variance in the groundwater level time series. 


\section{Appendix 3. Extrapolated 30-Year Precipitation Values Interpolated Spatially across the Mississippi Embayment Regional Aquifer Study Area}

A

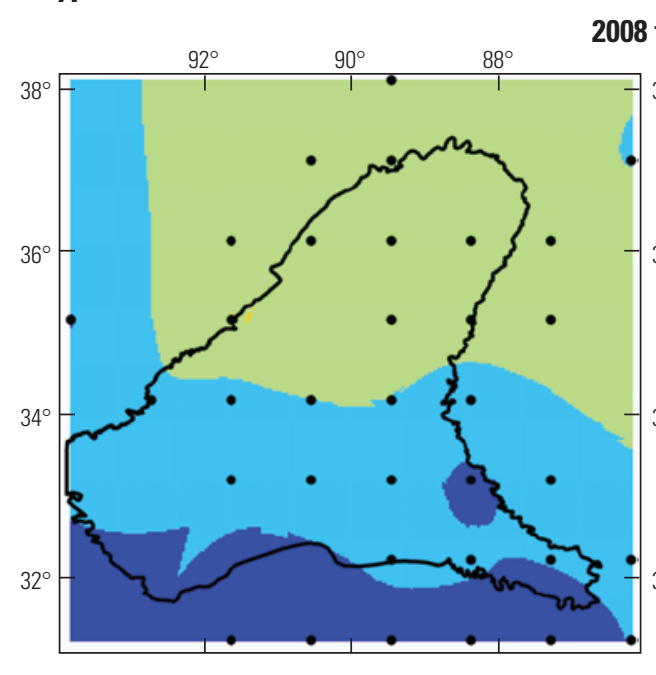

2008 to 2010

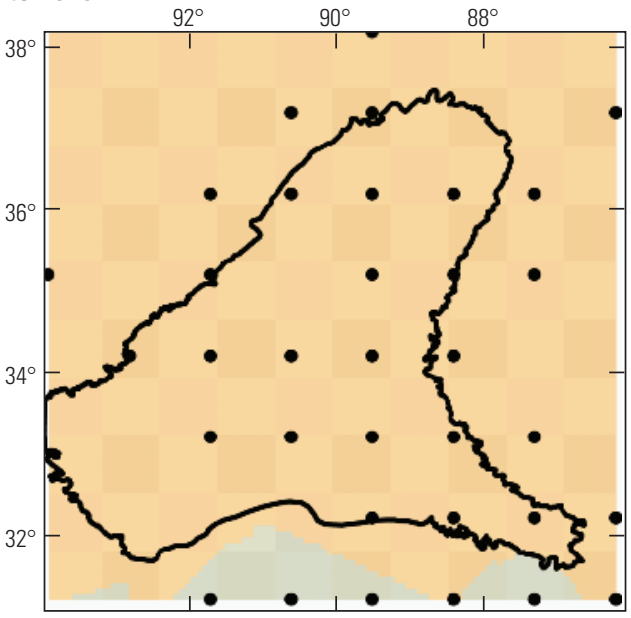

2010 to 2012

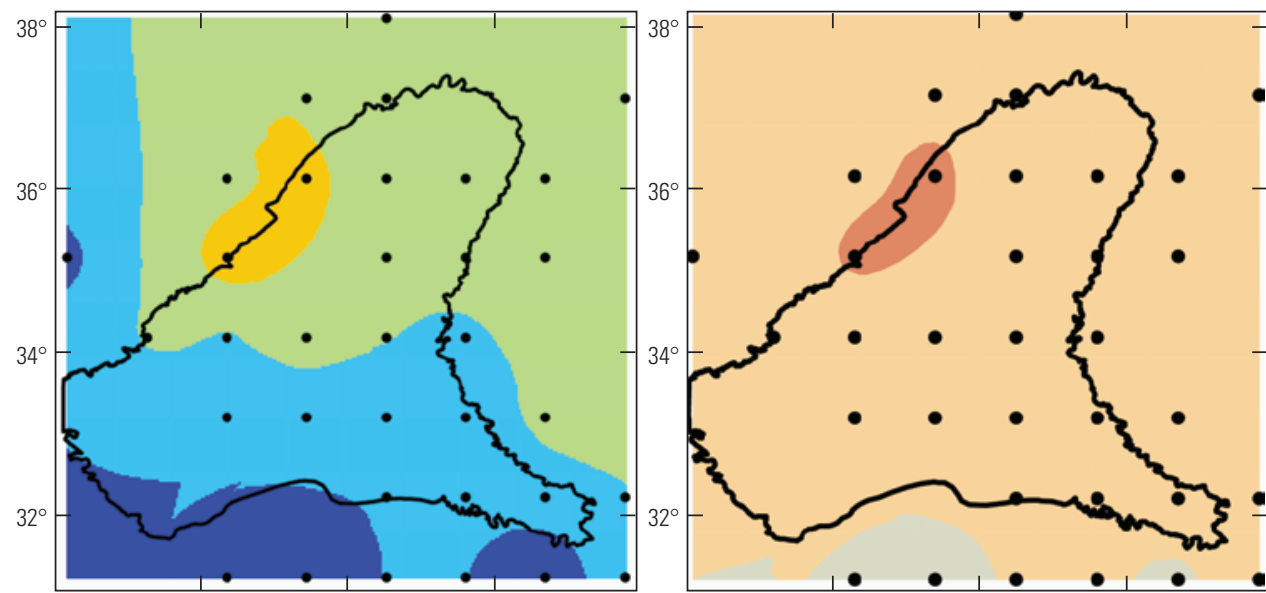

2012 to 2014
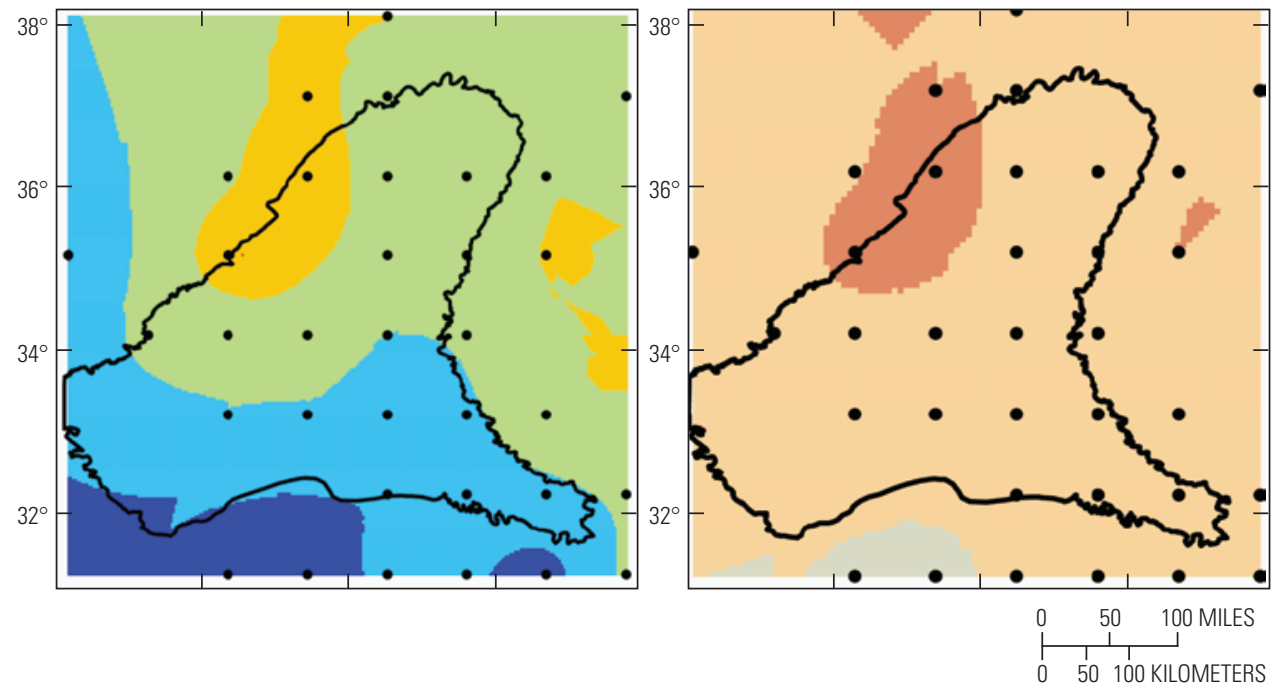

\section{EXPLANATION}

2-year average extrapolated annual precipitation, in inches

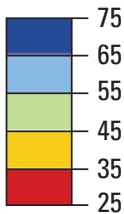

Deviation of 2-year average extrapolated annual precipitation from the average observed annual precipitation, in percent

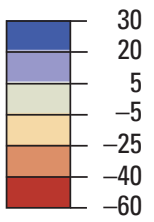

- Meteorological station

Figure 3-1. The extrapolated 30-year precipitation values interpolated spatially across the Mississippi Embayment Regional Aquifer Study area are shown as $A$, 2-year average extrapolated annual precipitation (in inches) and as $B$, deviation of the 2-year average extrapolated annual precipitation from the average observed annual precipitation (in percent) for the time period 2008 to 2038. 
$\boldsymbol{A}$

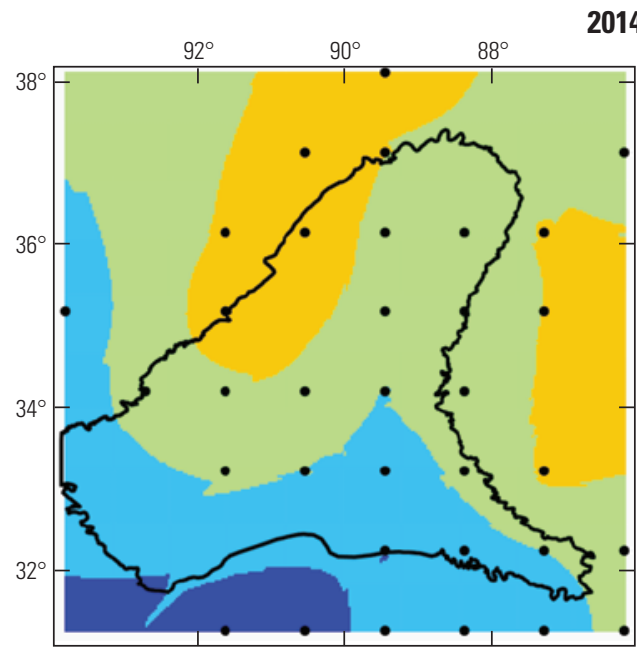

2014 to 2016

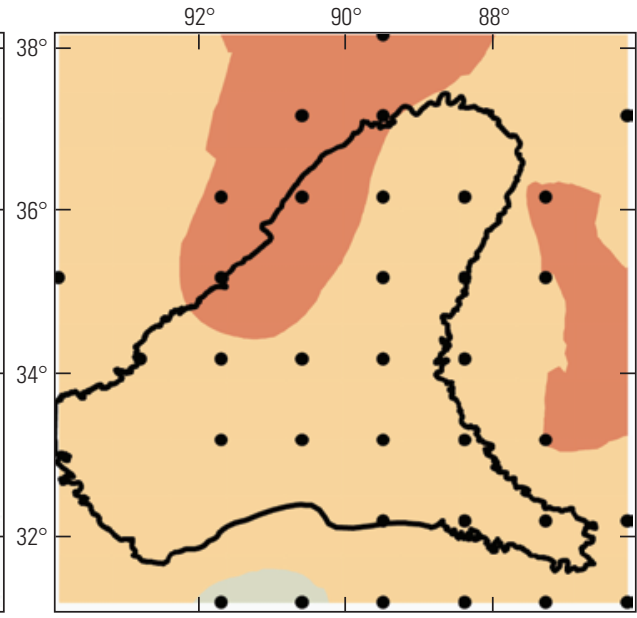

2016 to 2018
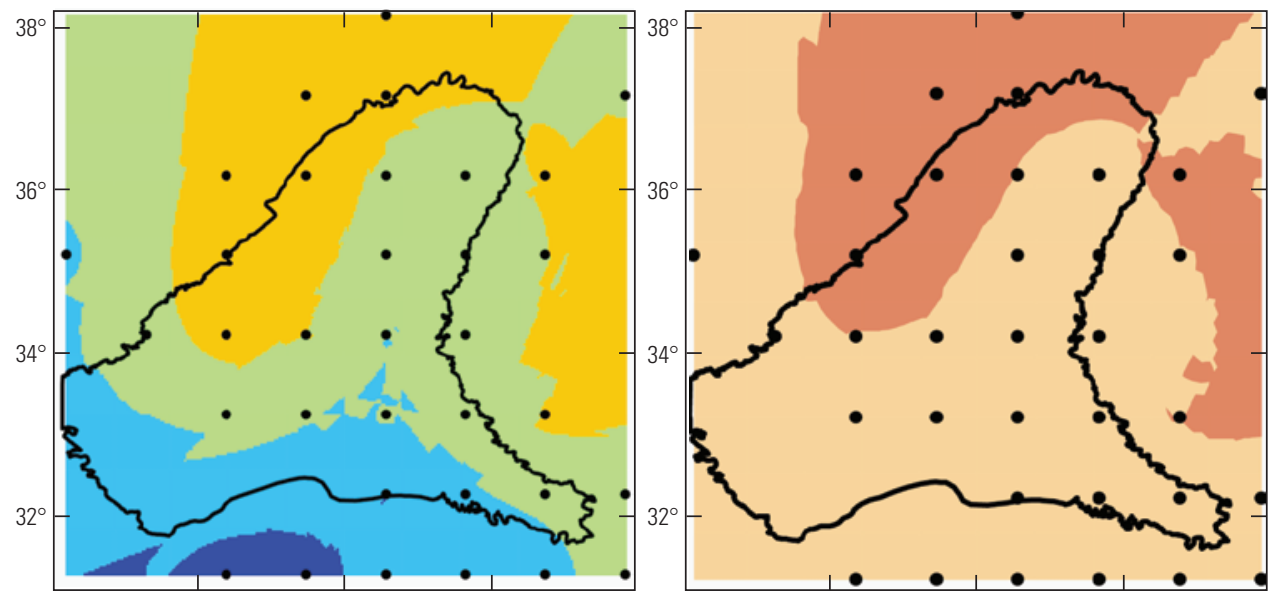

2018 to 2020
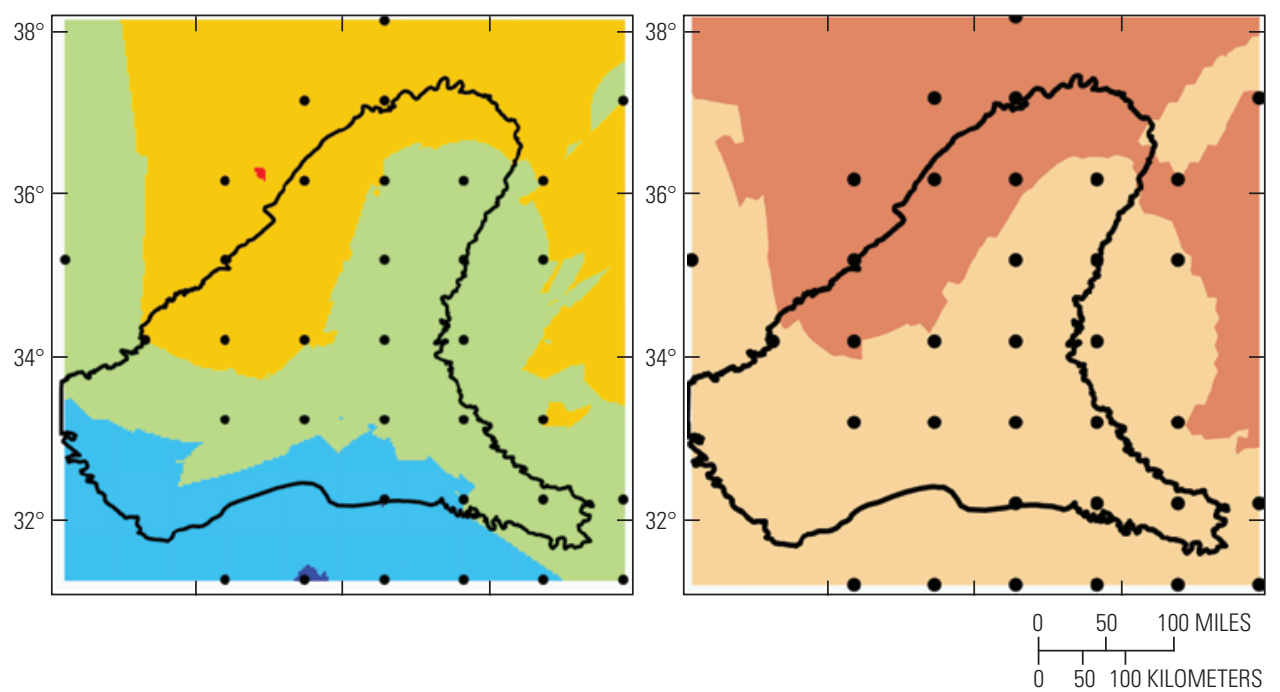

\section{EXPLANATION}

2-year average extrapolated annual precipitation, in inches

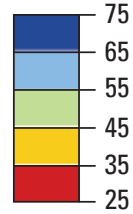

Deviation of 2-year average extrapolated annual precipitation from the average observed annual precipitation, in percent

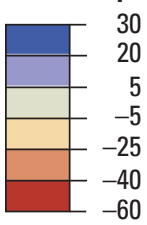

- Meteorological station

Figure 3-1. The extrapolated 30-year precipitation values interpolated spatially across the Mississippi Embayment Regional Aquifer Study area are shown as $A$, 2-year average extrapolated annual precipitation (in inches) and as $B$, deviation of the 2-year average extrapolated annual precipitation from the average observed annual precipitation (in percent) for the time period 2008 to 2038.-Continued 
$\boldsymbol{A}$

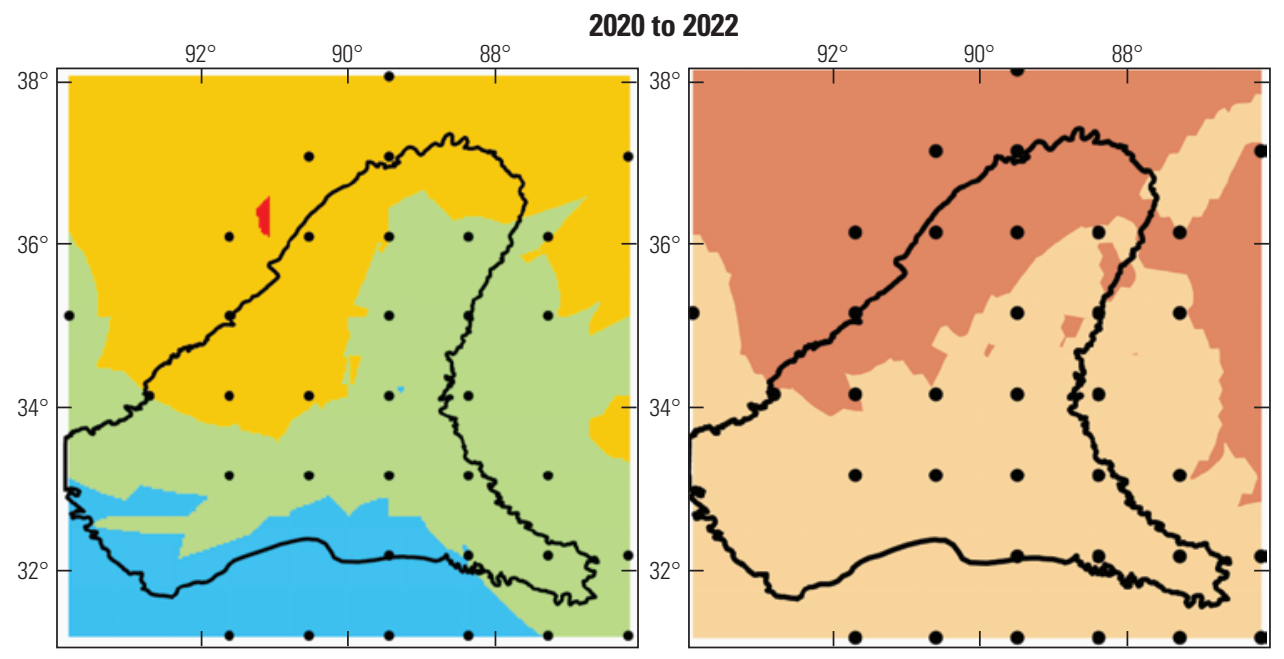

2022 to 2024

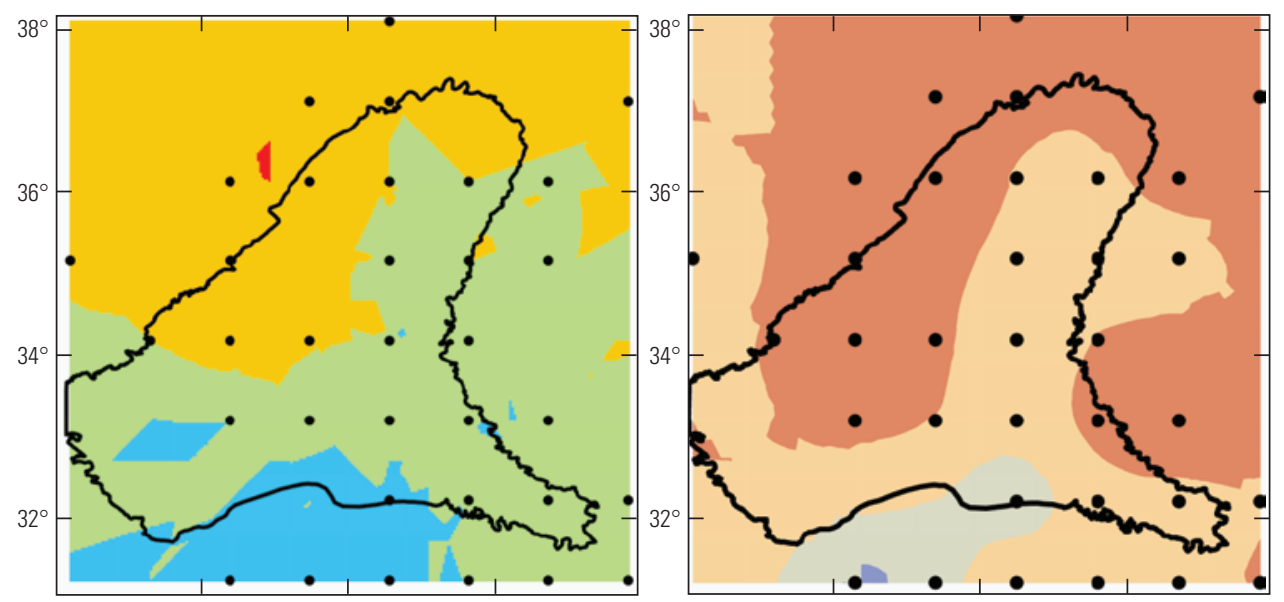

2024 to 2026

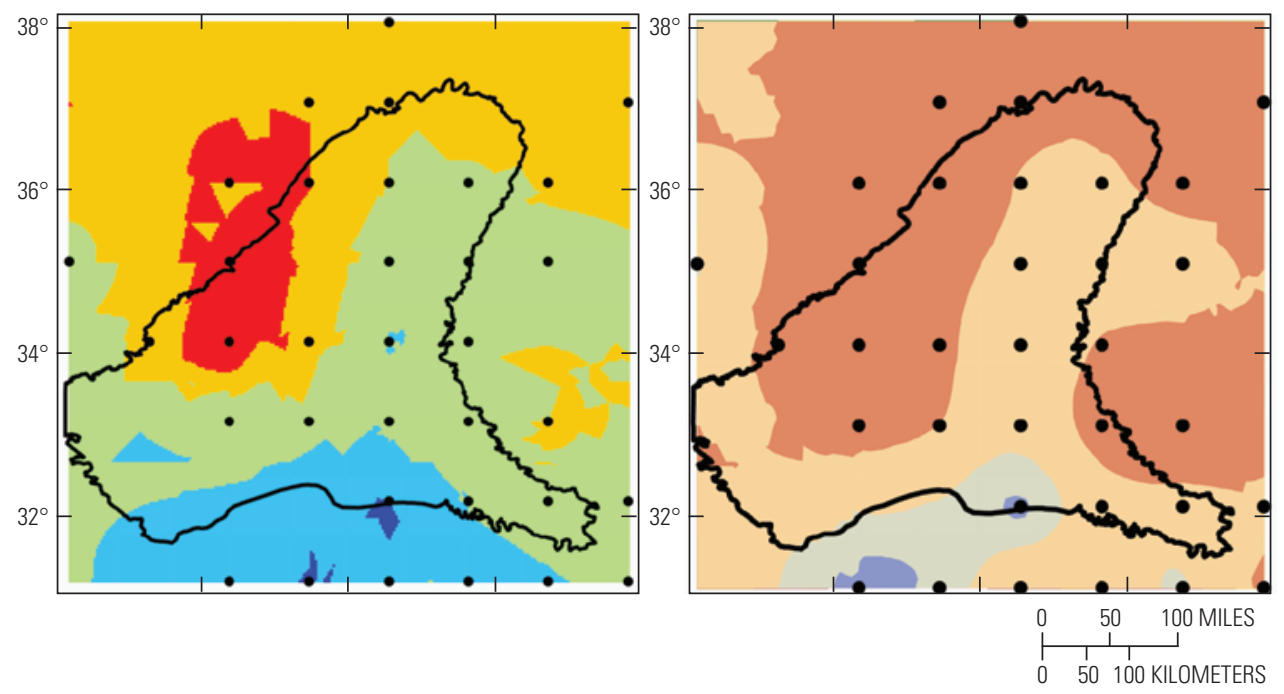

\section{EXPLANATION}

2-year average extrapolated annual precipitation, in inches

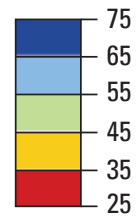

Deviation of 2-year average extrapolated annual precipitation from the average observed annual precipitation, in percent

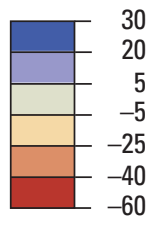

- Meteorological station

Figure 3-1. The extrapolated 30-year precipitation values interpolated spatially across the Mississippi Embayment Regional Aquifer Study area are shown as $A$, 2-year average extrapolated annual precipitation (in inches) and as $B$, deviation of the 2-year average extrapolated annual precipitation from the average observed annual precipitation (in percent) for the time period 2008 to 2038.-Continued 
$\boldsymbol{A}$

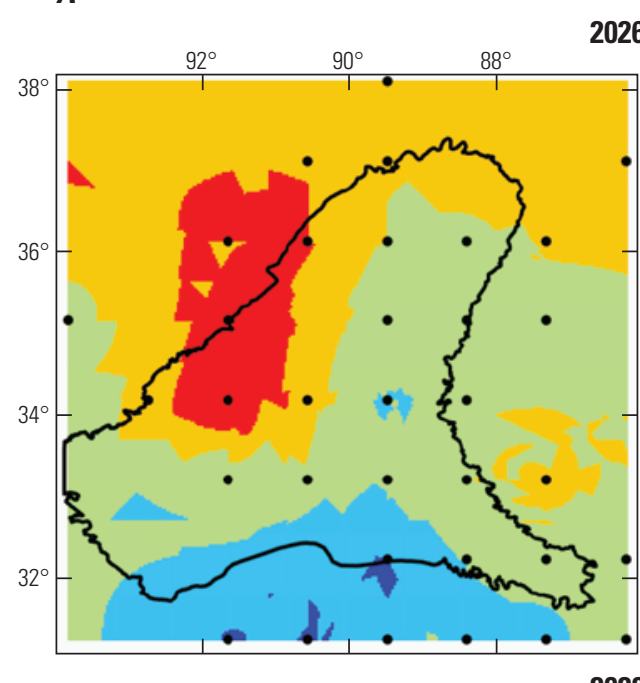

2028 to 2030

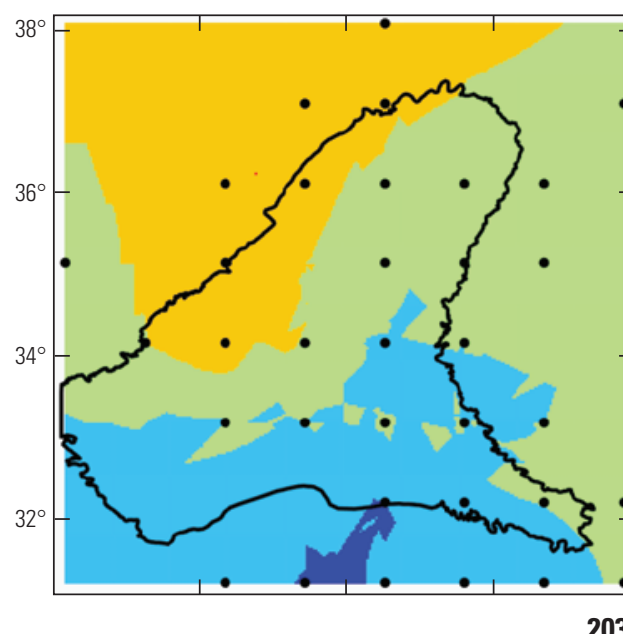

2030 to 2032
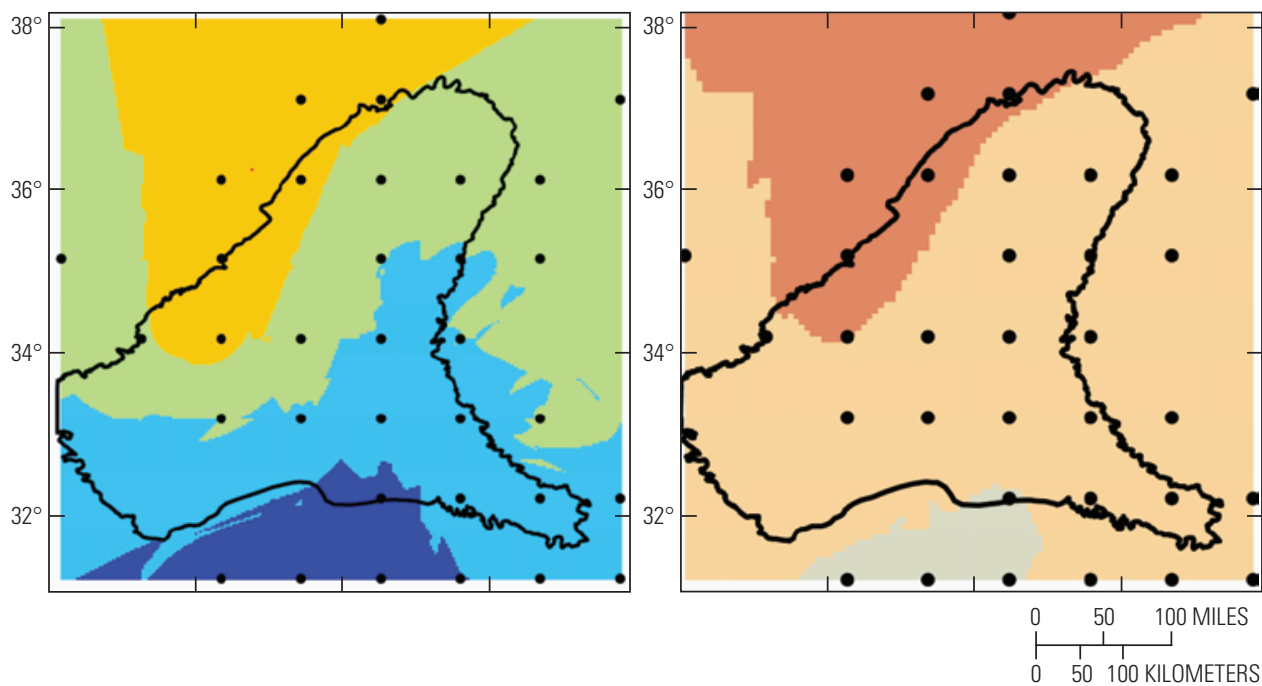

\section{EXPLANATION}

2-year average extrapolated annual precipitation, in inches

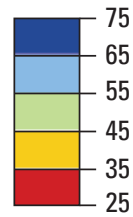

Deviation of 2-year average extrapolated annual precipitation from the average observed annual precipitation, in percent

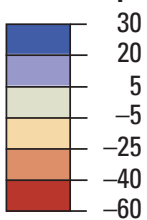

- Meteorological station

Figure 3-1. The extrapolated 30-year precipitation values interpolated spatially across the Mississippi Embayment Regional Aquifer Study area are shown as A, 2-year average extrapolated annual precipitation (in inches) and as $B$, deviation of the 2-year average extrapolated annual precipitation from the average observed annual precipitation (in percent) for the time period 2008 to 2038.-Continued 
$\boldsymbol{A}$

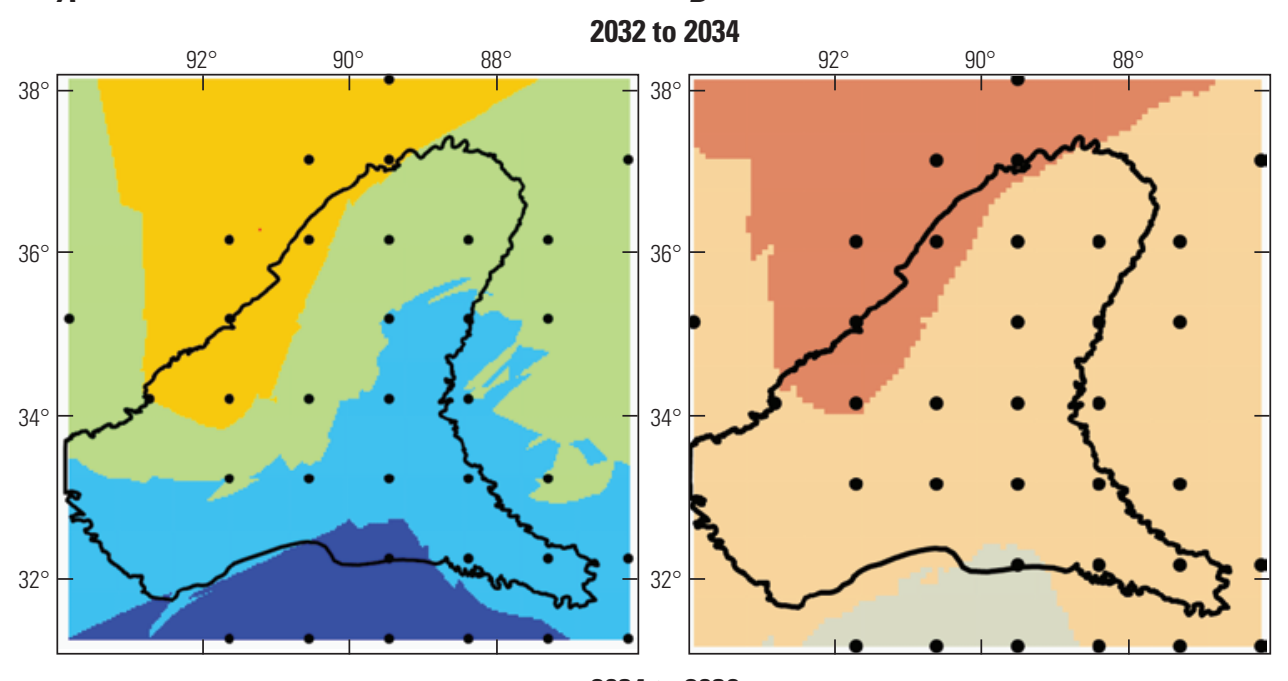

2034 to 2036

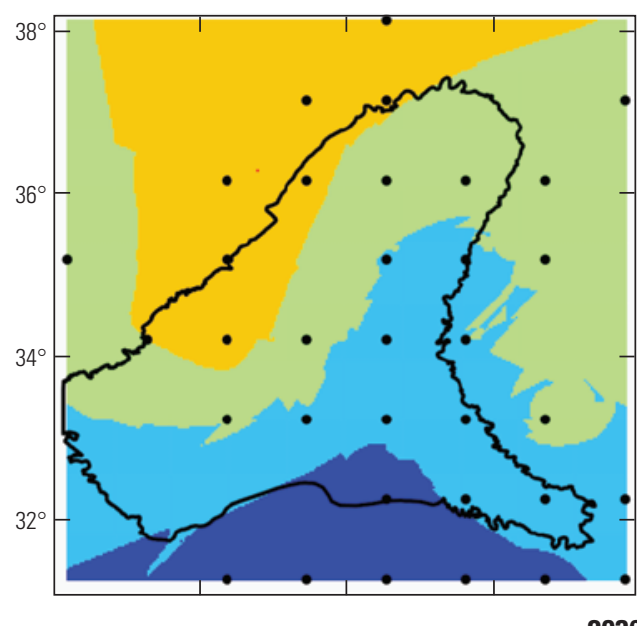

2036 to 2038
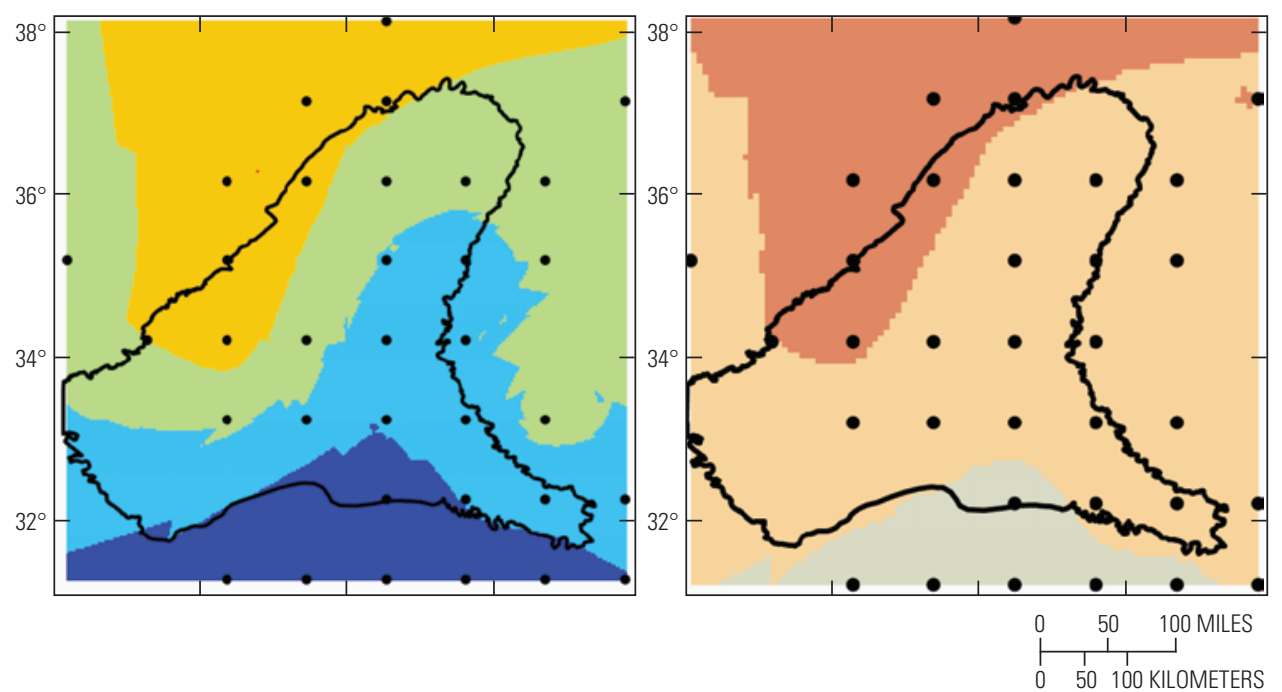

\section{EXPLANATION}

2-year average extrapolated annual precipitation, in inches

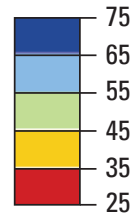

Deviation of 2-year average extrapolated annual precipitation from the average observed annual precipitation, in percent

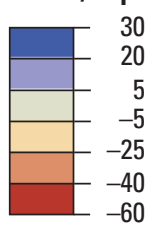

- Meteorological station

Figure 3-1. The extrapolated 30-year precipitation values interpolated spatially across the Mississippi Embayment Regional Aquifer Study area are shown as $A$, 2-year average extrapolated annual precipitation (in inches) and as $B$, deviation of the 2-year average extrapolated annual precipitation from the average observed annual precipitation (in percent) for the time period 2008 to 2038.-Continued 
Publishing support provided by:

Lafayette and Rolla Publishing Service Centers

For additional information concerning this publication, contact:

Director, USGS Arkansas Water Science Center

401 Hardin Road

Little Rock, AR 72211

(501) 228-3600

Or visit the Arkansas Water Science Center Web site at: http://ar.water.usgs.gov 




\section{Groundwater Availability of the Mississippi Embayment}

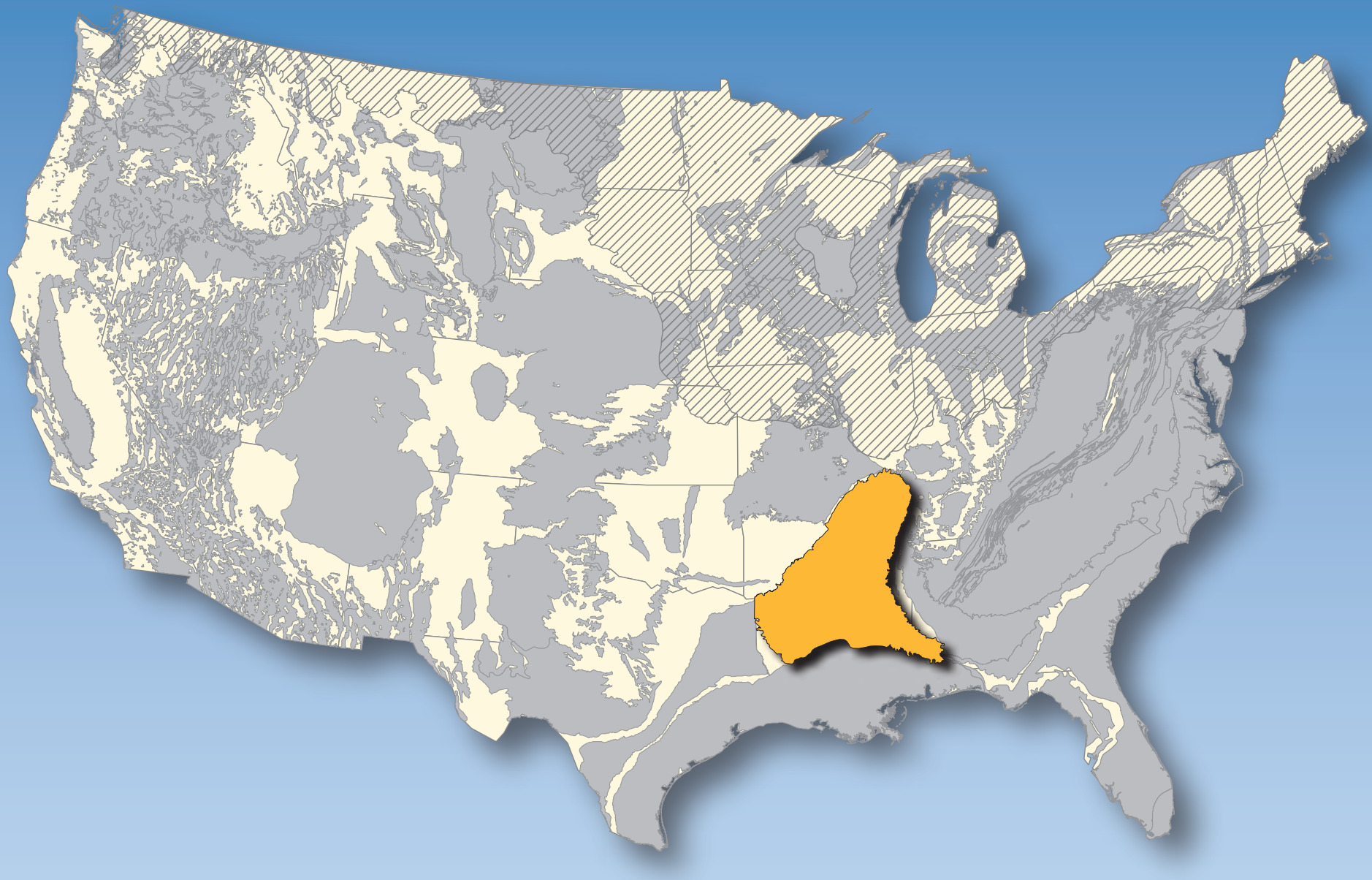

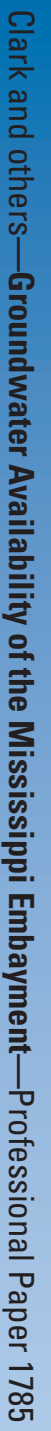

